SIMULATION OF EFFECTS OF GROUND-WATER DEVELOPMENT ON WATER LEVELS IN GLACIAL-DRIFT AQUIFERS IN THE BROOTEN-BELGRADE AREA, WEST-CENTRAL MINNESOTA

By Geoffrey N. Delin

U.S. GEOLOGICAL SURVEY

Water-Resources Investigations Report 88-4193

Prepared in cooperation with the

MINNESOTA DEPARTMENT OF NATURAL RESOURCES and the WESTERN MINNESOTA RESOURCE CONSERVATION AND

DEVELOPMENT ASSOCIATION

St. Paul, Minnesota 
U.S. DEPARTMENT OF THE INTERIOR

MANUEL LUJAN, JR., Secretary

U.S. GEOLOGICAL SURVEY

Dallas L. Peck, Director

For additional information

write to:

District Chief

U.S. Geological Survey Water Resources Division 702 Post Office Building

St. Paul, Minnesota 55101
Copies of this report can be purchased from:

U.S. Geological Survey Books and Open-File Reports Federal Center Box 25425

Denver, Colorado 80225 


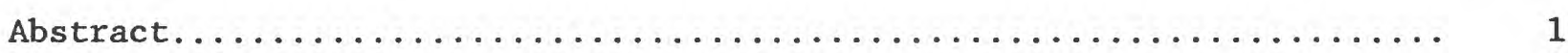

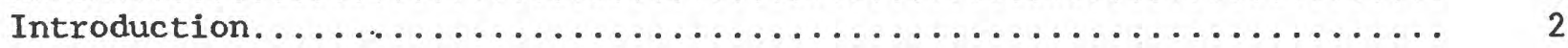

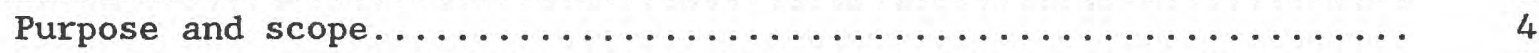

Previous investigations............................... 4

Location and description of study area and modeled area........ 4

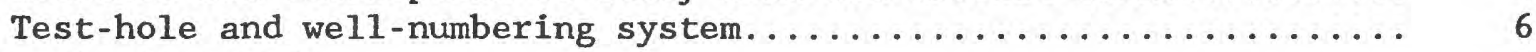

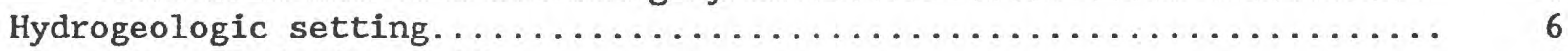

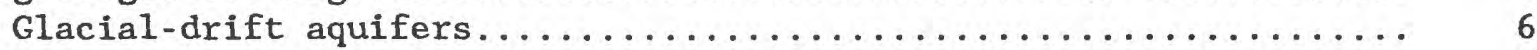

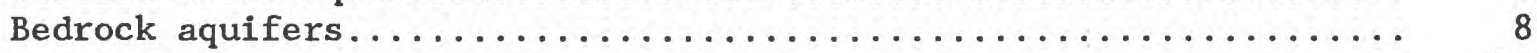

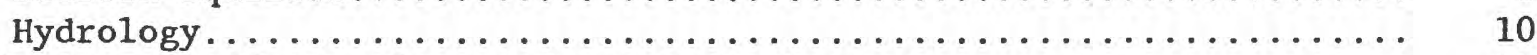

Simulation of effects of ground-water development............. 11

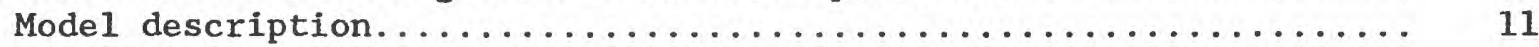

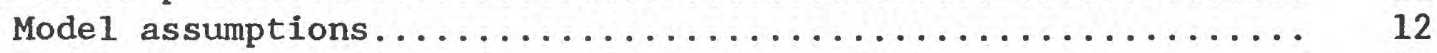

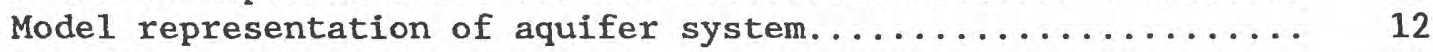

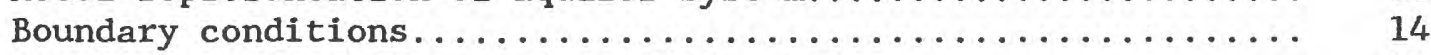

Simulation of aquifers and confining units............ 19

Simulation of streams, ground-water withdrawals,

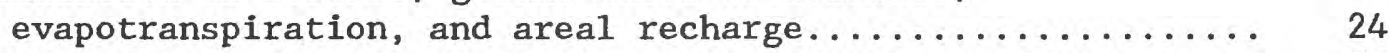

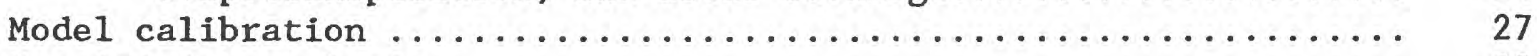

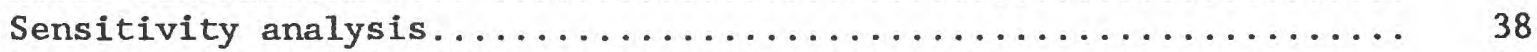

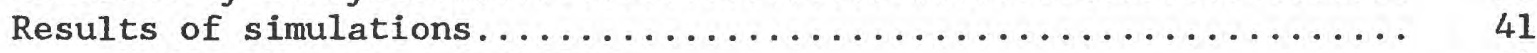

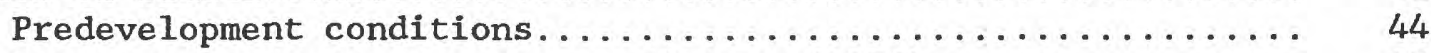

Development during drought conditions (1976)............ 47

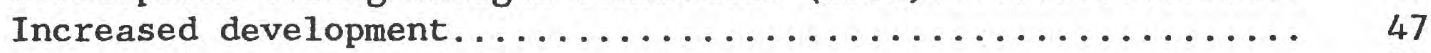

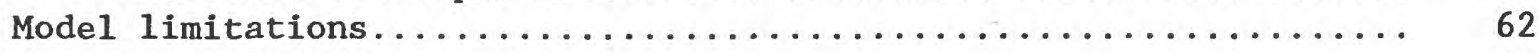

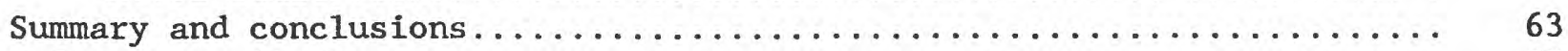

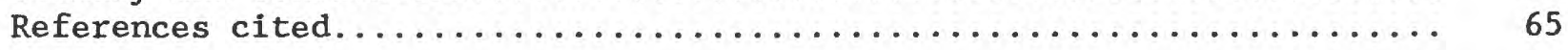

\section{ILLUSTRATIONS}

Figure 1. Map showing location of study area and trace of

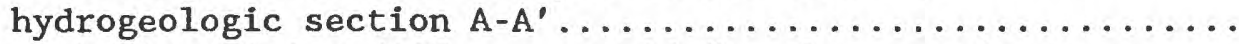

2. Map showing finite-difference grid for the ground-water-

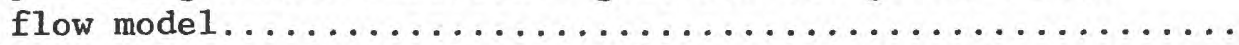

3. Diagram showing test-hole and well-numbering system.........

4. Hydrogeologic section $A-A^{\prime}$ showing drift lithology and schematic representation of layering for the model........

5. Map showing model representation of regional hydrologic

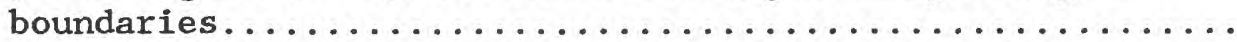

6-12. Maps showing boundary conditions and differences between model-computed water levels and water levels measured in 1985 in:

6. The surficial aquifer, layer $1 \ldots \ldots \ldots \ldots \ldots \ldots \ldots \ldots \ldots$

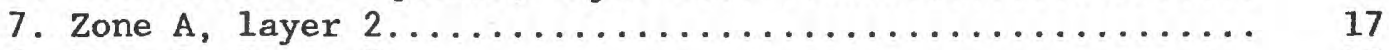

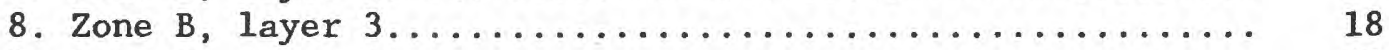

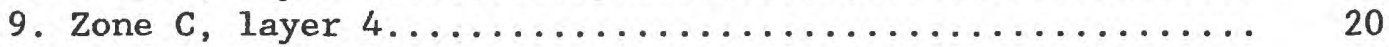

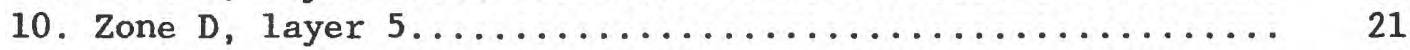

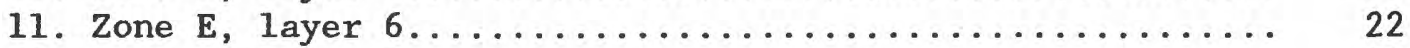

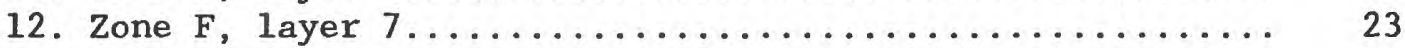




\section{ILLUSTRATIONS - - Continued}

Page

Figure 13. Map showing conceptualized coalescing of confined aquifers with deposits beneath Lakes Minnewaska and Koronis........ 25

14. Map showing river cells and river reaches for which groundwater discharge rates were calculated............... 26

15-21. Maps showing location of pumped wells simulated in:

15. The surficial aquifer, layer $1 \ldots \ldots \ldots \ldots \ldots \ldots \ldots \ldots . \ldots \ldots$

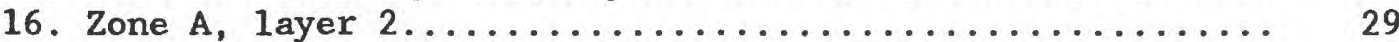

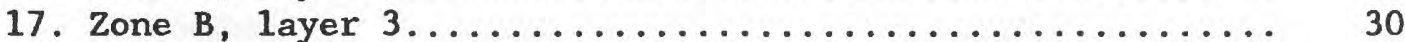

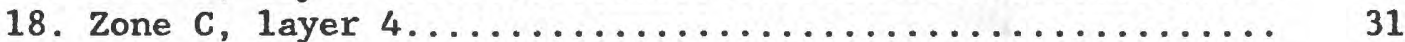

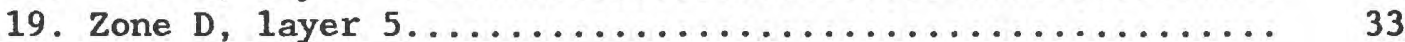

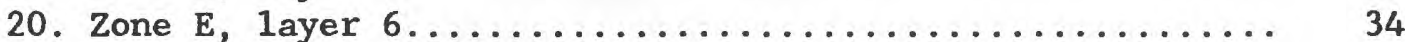

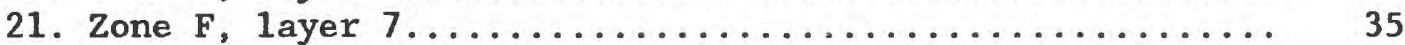

22. Diagram showing relation among parameters used in sensitivity analysis for the Brooten-Belgrade ground-

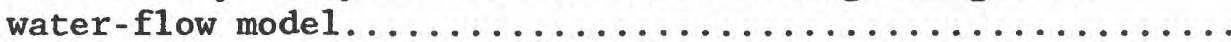

23-36. Maps showing mode1-computed water-level declines in:

23. The surficial aquifer (1ayer 1 ) that have resulted from pumping under steady-state conditions from

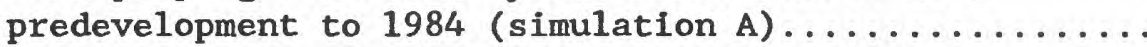

24. Zone C (layer 4) that have resulted from pumping under steady-state conditions from predevelopment

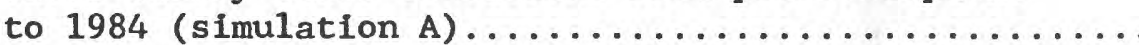

25. The surficial aquifer (layer 1 ) following an extended drought (simulation $B$ )..................... 48

26. Zone A (1ayer 2) following an extended drought

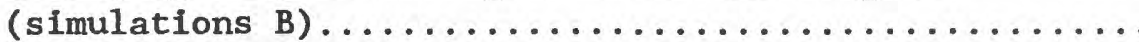

27. Zone B (1ayer 3 ) following an extended drought

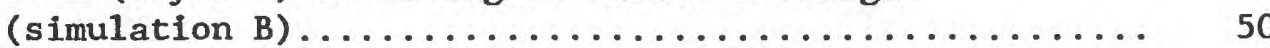

28. Zone C (1ayer 4) following an extended drought

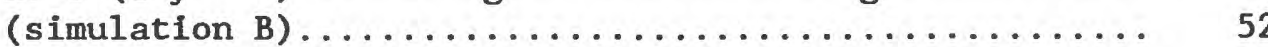

29. Zone D (1ayer 5) following an extended drought

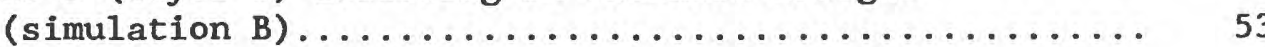

30. Zone E (layer 6) following an extended drought

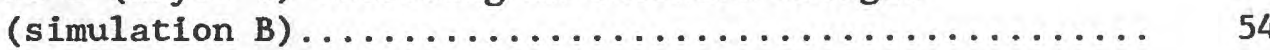

31. Zone $F$ (layer 7) following an extended drought

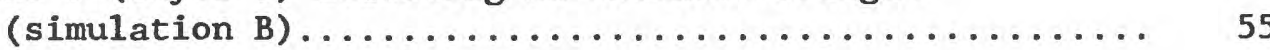

32. Zone A (layer 2) following increased development

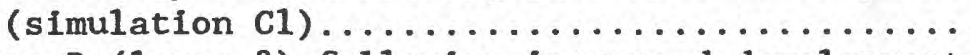

33. Zone B (layer 3) following increased development

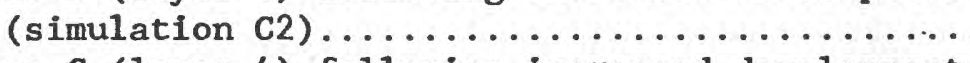

34. Zone C (layer 4) following increased development

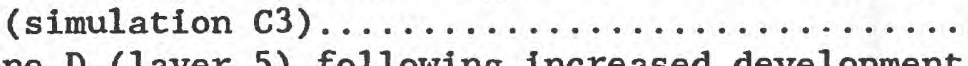

35. Zone D (layer 5) following increased development

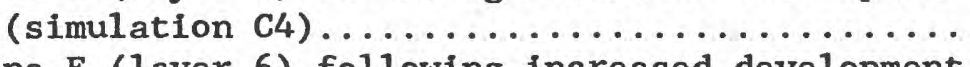

36. Zone $\mathrm{E}$ (layer 6 ) following increased development (simulation C5). 


\section{TABLES}

Page

Table 1. Relation between model layers and hydrogeologic units........ 13

2. Mode1-computed and calculated ground-water discharge to the East Branch Chippewa and North Fork Crow Rivers.......... 37

3. Steady-state water budget for the calibrated mode1.......... 39

4. Summary of results of hypothetical model simulations A, B, C1,

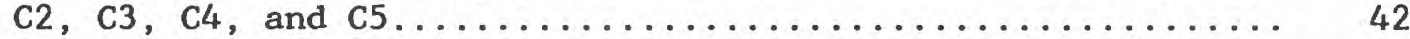

5. Mode1-computed water budget for the steady-state calibration and hypothetical model simulations A, B, C1, C2, C3, C4,

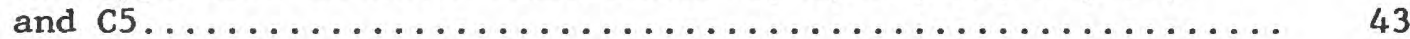

6. Pumpage and model-computed leakage between aquifers........ 44

\section{CONVERSION FACTORS AND VERTICAL DATUM}

Multiply inch-pound unit

foot (ft)

foot per day ( $\mathrm{ft} / \mathrm{d}$ )

foot squared per day $\left(f t^{2} / d\right)$

foot per mile

cubic foot per second $\left(\mathrm{ft}^{3} / \mathrm{s}\right)$

gallon

gallon per minute (gal/min)

million gallons per year

inch (in.)

inch per year (in/yr)

mile (mi)

square mile $\left(\mathrm{mi}^{2}\right)$
By

0.3048

0.3048

0.09294

0.1894

0.02832

3.785

0.06308

0.00012

25.4

25.4

1.609

2.590
To obtain SI unit

meter

meter per day

meter squared per day

meters per kilometer

cubic meter per second

liter

liter per second

cubic meter per second

millimeter

millimeter per year

kilometer

square kilometer

Sea level: In this report "sea level" refers to the National Geodetic Vertical Datum of 1929 - - a geodetic datum derived from a general adjustment of the first-order level nets of both the United States and Canada, formerly called Sea Leve1 Datum of 1929. 


\title{
SIMULATION OF EFFECTS OF GROUND-WATER DEVELOPMENT ON WATER LEVELS IN GLACIAL-DRIFT AQUIFERS IN THE BROOTEN-BELGRADE AREA, WEST-CENTRAL MINNESOTA
}

By Geoffrey N. Delin

\begin{abstract}
Ground-water flow in the confined-and unconfined-drift aquifers in the Brooten-Belgrade area of west-central Minnesota was simulated with a threedimensional finite-difference ground-water-flow model. Model results indicate that about 96 percent of the total inflow to the modeled area is from precipitation. Discounting evapotranspiration, 63 percent of the total outflow is ground-water discharge to the East Branch Chippewa and North Fork Crow Rivers, and 34 percent is ground-water pumpage.

The model was used to simulate the steady-state effects of below-normal precipitation (drought) and hypothetical increases in ground-water development. Model results indicate that reduced recharge and increased pumping during a hypothetical 3-year extended drought would lower regional water levels from 2 to 5 feet in each aquifer and as much as 20 feet in the lowermost aquifer zone; ground-water discharge to the East Branch Chippewa and North Fork Crow Rivers would be reduced by 38 percent. The addition of 10 to 20 hypothetical wells in confined aquifers, pumping 123 to 246 million gallons per year, would result in regional water-level declines of 0.1 to 0.5 feet. Simulated water-level declines in wells completed in the lower part of the system would be as much as 5.0 feet as a result of pumping 246 million gallons per year from 20 hypothetical wells. Water-level declines in overlying and underlying aquifers would range from 0.4 to 2.8 feet. Ground-water discharge to the East Branch Chippewa and North Fork Crow Rivers would be unaffected by the pumpage.
\end{abstract}


In the $1970^{\prime} \mathrm{s}$ and $1980^{\prime} \mathrm{s}$, pumpage of water from confined aquifers has increased dramatically for irrigation and for municipal, agricultural-products processing, and other industrial supplies in Minnesota. The increase is due primarily to an increase in ground water used for irrigation following the 1976-77 drought. The Minnesota Department of Natural Resources (MDNR) is concerned about the rapid increase in withdrawals from confined aquifers in various parts of the State because of uncertainty about (1) long-term yields of wells open to these aquifers, (2) effect of pumping on water levels, and (3) possible interference between nearby wells pumping from the same aquifer. In the Brooten-Belgrade area, west-central Minnesota (fig. 1), pumpage from confined-drift aquifers is increasing rapidly. The area, popularly known as the Bonanza Valley, is underlain by a surficial sand-and-gravel aquifer that provides adequate yields for irrigation systems over about half the area (Van Voast, 1971). However, in the remaining area, the surficial aquifer is thin and wells have been drilled into confined aquifers that are separated from surficial deposits by till and clay. These confined aquifers consist of glacial outwash of Quaternary age and sand of Cretaceous age.

Although numerous wells and test holes have been completed in the confined aquifers, little is known about the continuity of the aquifers or the hydraulic response to pumpage. The water quality and long-term yield of wells in the aquifers also is poorly known. These uncertainties make it difficult for the MDNR to issue appropriation permits and to manage the ground-water resources efficiently. Consequently, the U.S. Geological Survey, in cooperation with the MDNR, began a study to investigate the areal extent, hydraulic properties, and water quality of confined aquifers in the Brooten-Belgrade area and to determine the probable effects of continued development on water levels, storage, potential well yields, and water quality in both the confined and unconfined aquifers.

The objectives of this study were to (1) determine the areal extent, thickness, and hydraulic properties of confined-drift and Cretaceous aquifers in the study area, (2) investigate the vertical hydraulic connection between confineddrift and surficial aquifers and estimate the quantity of vertical leakage into confined-drift aquifers from overlying deposits, (3) estimate the long-term yield of wells penetrating confined-drift aquifers, (4) estimate the effects of continued development on water levels and on streamflow, (5) provide the MDNR with a set of management tools that can be used to assess the effects of future ground-water withdrawals, and (6) assess the quality of water from confineddrift and Cretaceous aquifers and its suitability for irrigation and other purposes. 


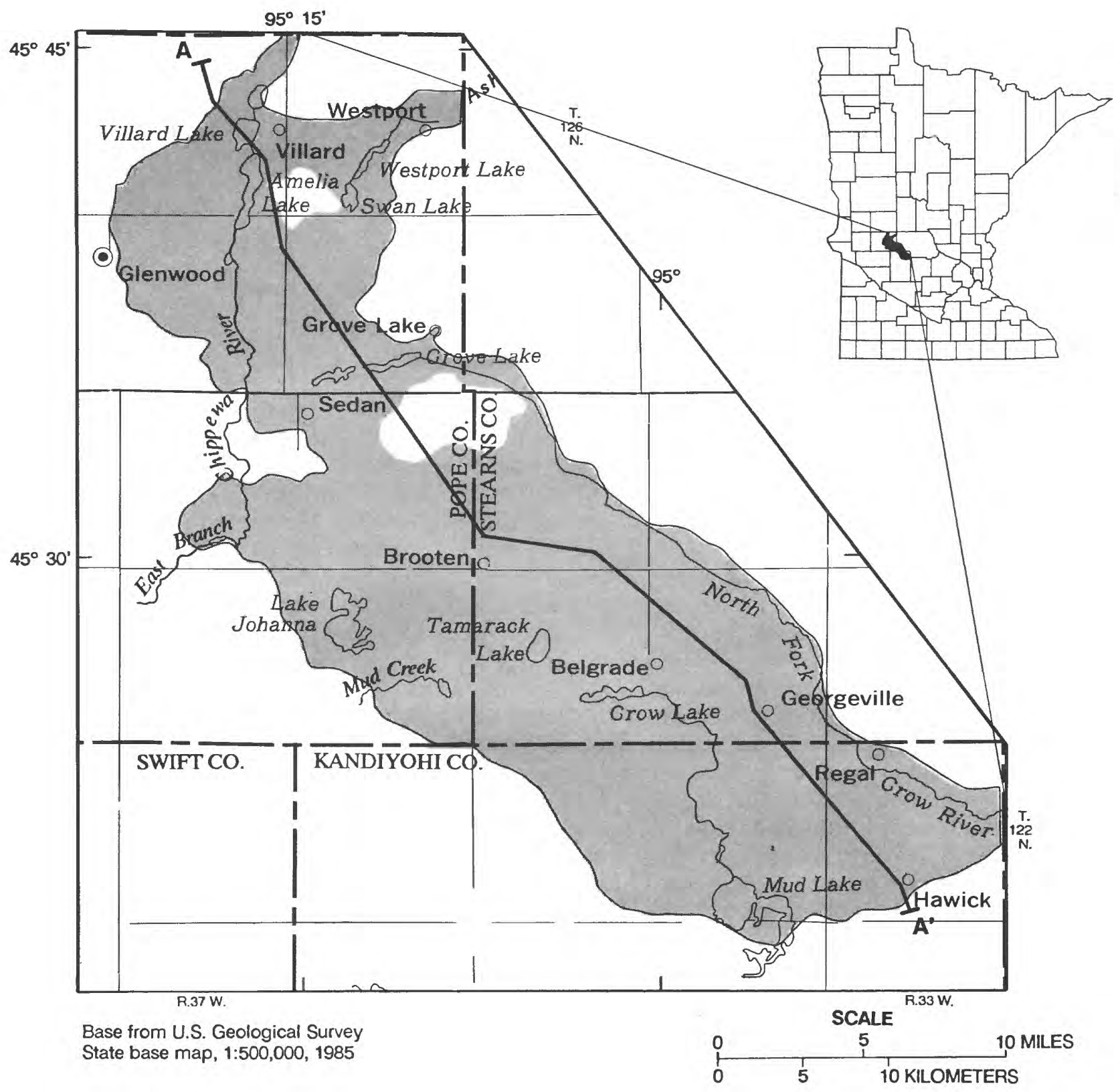

EXPLANATION

Brooten-Belgrade sand plain

$A \longmapsto A^{\prime}$ Trace of section

Figure 1.--Location of study area and trace of hydrogeologic section A-A' 


\section{Purpose and Scope}

The purpose of this report is to present the results of a study to estimate the effects of ground-water development on water levels in the study area. The estimation was done by use of a ground-water-flow model. The model was used to address objectives 2 through 4 of the overall study. This report describes model-simulated effects of ground-water development plus (1) the sources and types of data used in constructing the simulation model, (2) model calibration, (3) sensitivity analysis, (4) results of model simulations, and (5) limitations of the model. This report supplements an additional U.S. Geological Survey report published in conjunction with this study, in which Delin (1988) provides a detailed hydrogeologic description of the confineddrift aquifers in the area.

\section{Previous Investigations}

Winchell and Upham (1888) first summarized the geology and natural history of west-central Minnesota. An early description of the glacial geology in the area is presented by Leverett (1932). A more recent interpretation of the glacial geology is described by Wright and Ruhe (1965) and Wright (1972a). Wright (1972b) provides a general description of the physiography of the study area. Hall and others (1911) and Theil (1944) investigated the hydrology of southern Minnesota including Kandiyohi County. A general description of the geology and ground water in Pope and Stearns Counties is included in a report by Allison (1932). A general description of ground water in the study area is provided by Lindholm and Norvitch (1976). A general description of the geology and water resources of the study area is presented in the hydrologic atlases of the Crow River watershed by Lindholm and others (1974), the Chippewa River watershed by Cotter and others (1968), and Mississippi and Sauk Rivers watershed by Helgesen and others (1975). A general description of irrigation potential in the Bonanza Valley (Brooten-Belgrade) area is presented by Ross (1971). Ground-water resources of surficial aquifers in the study area were studied in detail by Van Voast (1971). Wolf (1976) provided a general description of buried aquifers in the area.

\section{Location and Description of Study Area and Modeled Area}

The study area covers about 300 square miles $\left(\mathrm{mi}^{2}\right)$ in west-central Minnesota and includes parts of Pope, Stearns, and Kandiyohi Counties (fig. 1). The modeled area includes all of the study area and extends to natural hydrologic boundaries outside the study area (fig. 2). Hydrologic boundaries of the modeled area consist of perennial streams and ground-water divides. It was necessary to extend the model beyond the study-area boundary in order to accurately simulate $\mathrm{fl} \mathrm{g}^{\mathrm{w}}$ within the study area. The modeled area covers approximately 2,500 $\mathrm{mi}^{2}$ including parts of Pope, Stearns, Kandiyohi, Swift, Meeker, Douglas, and Todd Counties. The model grid was oriented in a northwest-southeast direction because of (1) the location of major hydrologic boundaries, (2) the areal extent of the confined aquifers, and (3) the direction of regional flow in the drift aquifers. The area is drained by the East Branch Chippewa River, a tributary of the Minnesota River, and by the North 


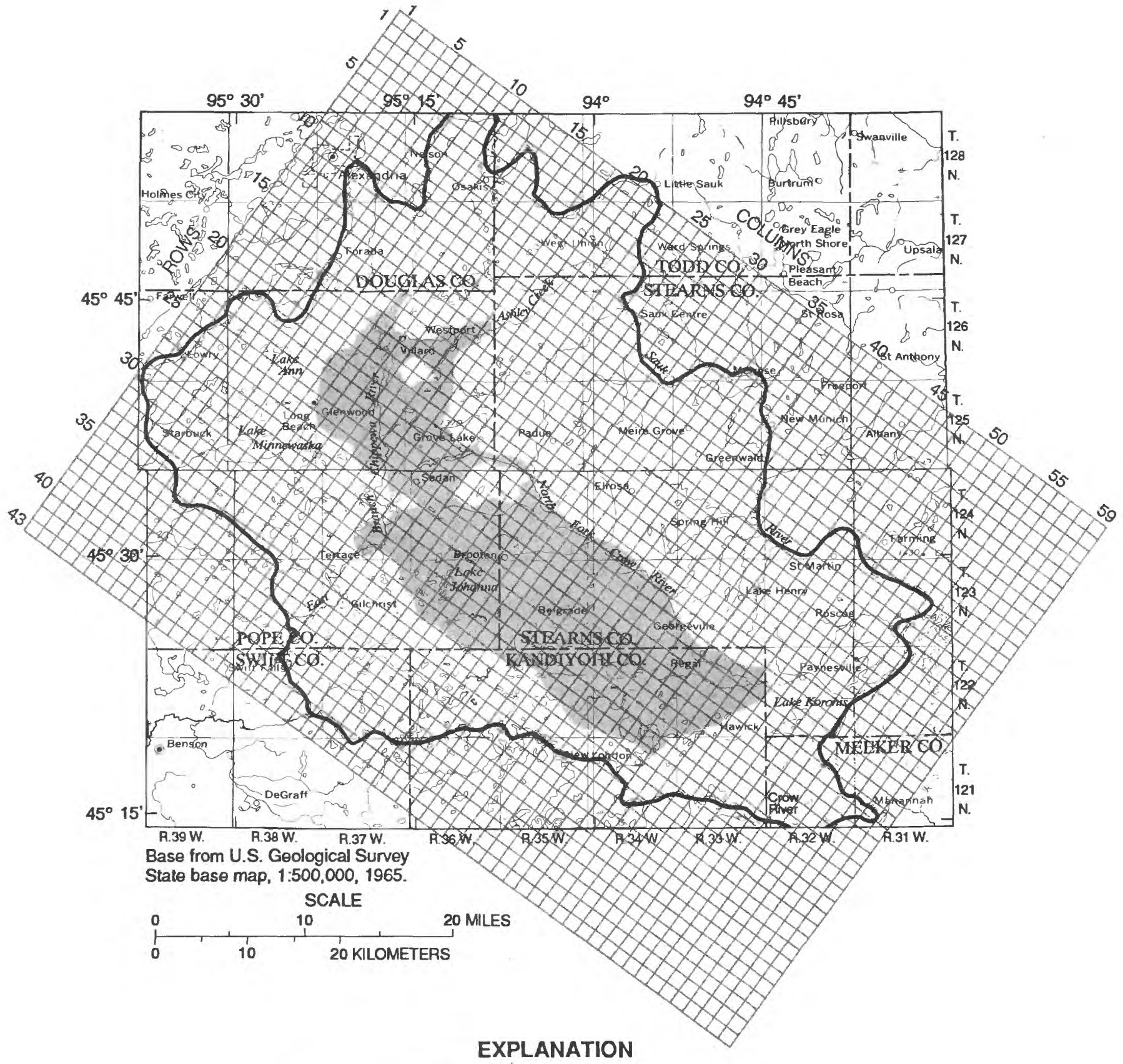

Study area

Hydrologic boundary

Figure 2.-Finite-difference grid for the ground-water-flow model 
and Middle Forks of the Crow River and the Sauk River, which are tributaries of the Mississippi River. The topography generally is flat or gently rolling. Average daily maximum temperatures range from about $21^{\circ} \mathrm{F}$ (degrees Fahrenheit) in January to $84^{\circ} \mathrm{F}$ in July (Baker and Strub Jr., 1965). Average daily minimum temperatures range from about $1.0^{\circ} \mathrm{F}$ in January to $60^{\circ} \mathrm{F}$ in July. Mean annual precipitation is about 24 in. (inches) (Baker and Kuehnast, 1978), a large part of which falls from May through September. Mean potential evapotranspiration is about $24 \mathrm{in.}$ and average annual runoff is about $3.5 \mathrm{in}$. (Baker and others, 1979).

\section{Test-Hole and Well-Numbering System}

The system used in this report for numbering wells and test holes is based on the U.S. Bureau of Land Management's system of land subdivision (township, range, and section) and is illustrated in figure 3 . The first numeral of a location number indicates the township, the second the range, and the third the section in which the point is located. Lower-case letters after the section number indicate the location within the section; the first letter denotes the 160-acre tract, the second the 40-acre tract, and the third the 10-acre tract. The letters A, B, C, and D are assigned in a counterclockwise direction, beginning in the northeast corner of each tract. The number of lower-case letters indicates the accuracy of the location number; if a point can be located within a 10-acre tract, three lower-case letters are shown in the location number. For example, the number 129.41.15ADC indicates a test hole or well located in the SW $1 / 4$ of the SE $1 / 4$ of the NE $1 / 4$ of section 15 , township 129 north, range 41 west.

\section{HYDROGEOLOGIC SETTING}

\section{Glacial-Drift Aquifers}

Glacial drift, consisting primarily of till and outwash, covers the entire modeled area. The drift ranges in thickness from about $200 \mathrm{ft}$ (feet) in the eastern part of the area to $500 \mathrm{ft}$ where it fills bedrock valleys in the southwestern part of the area. Drift in the area has been subdivided hydrogeologically into three types (1) sand and gravel deposits exposed at land surface that compose the unconfined (or surficial) aquifer, (2) till that overlies and confines deeper sand and gravel deposits, and (3) deeper sand and gravel deposits that compose the confined aquifers. Delin (1988) provides a detailed description of these deposits. A general description follows.

The surficial aquifer occurs as a broad outwash sand plain bounded on all sides by till and ice-contact deposits (Van Voast, 1971). The aquifer generally consists of very fine to coarse sand and gravel deposited during the last glacial retreat. Saturated thickness of the outwash ranges from about 10 feet in the north and northeast to about $60 \mathrm{ft}$ in the southwest (Van Voast, 1971). Clay beds as much as $30 \mathrm{ft}$ thick occur locally within the outwash. 


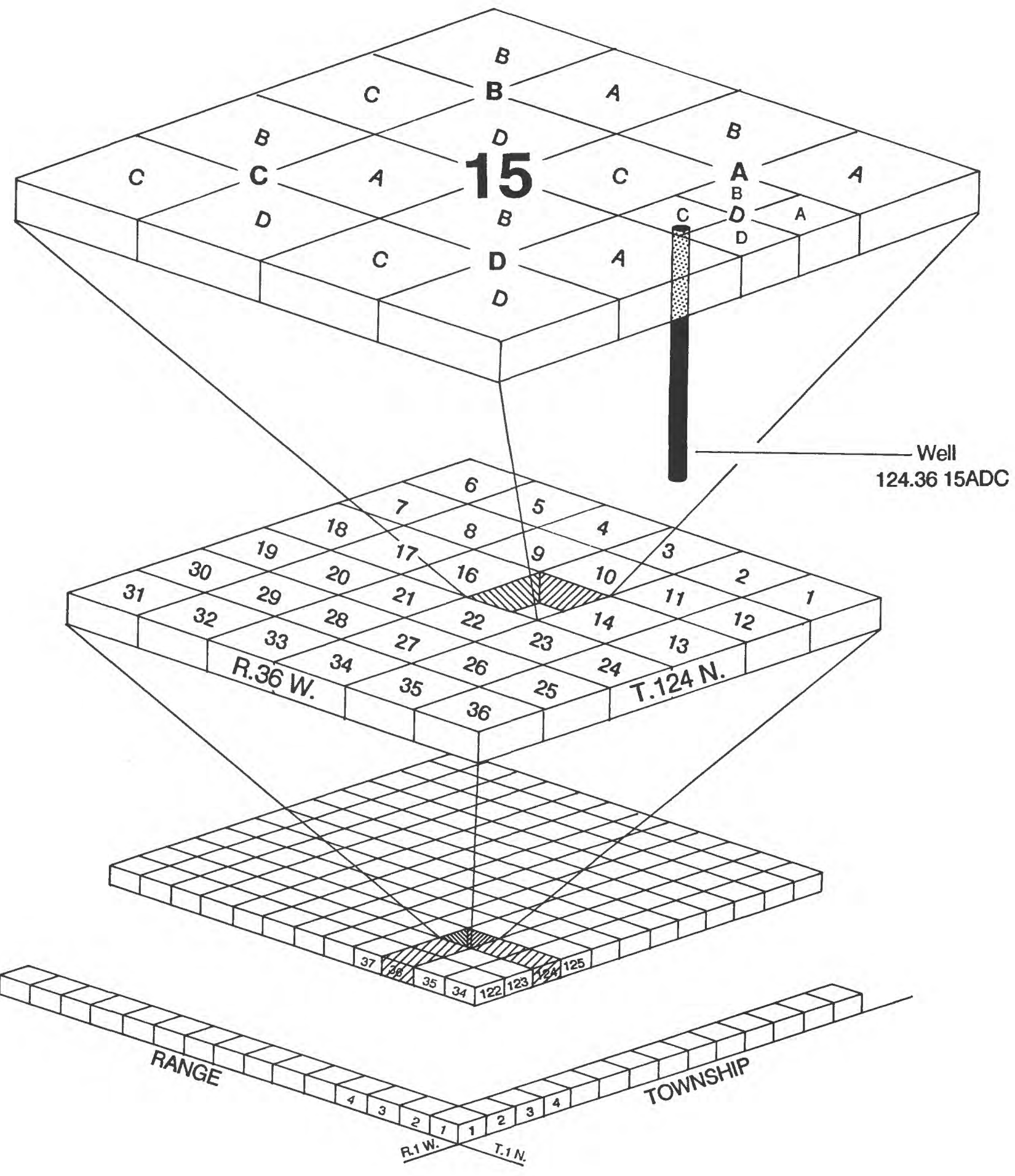

Figure 3.--Test-hole and well numbering system 
Till is an unsorted mixture of clay, silt, sand, gravel, and boulders. Till confining the deeper aquifers in the drift ranges in thickness from less than $5 \mathrm{ft}$ to about $220 \mathrm{ft}$ in various locations south and southwest of the area, between New London and Gilchrist. The average thickness of till confining beds is about $80 \mathrm{ft}$. Hydrogeologic section $A-A^{\prime}$ through the area (fig. 4) illustrates the relation between till and the principal aquifers in the area.

Confined-drift aquifers, herein referred to as confined aquifers, consist of saturated sand-and-gravel deposits bounded above, below, and laterally by til1. Using a technique presented by Delin (1986a), confined aquifers were identified in six zones within the modeled area (fig. 4). The basic assumptions for this technique are that (1) wells at a given altitude are completed in a single aquifer zone, (2) the sand and gravel deposits forming confined aquifers in each aquifer zone are continuous between known points of occurrence, and (3) thin, areally discontinuous sand and gravel deposits are considered to be distributed randomly, and, therefore, are ignored. The aquifer zones were assigned a letter designation, $\mathbf{A}$ through $\mathrm{E}$, corresponding to an increase in depth below land surface. Average thickness of the aquifers is between 15 and $20 \mathrm{ft}$, with a maximum known thickness of $110 \mathrm{ft}$. Depth to the aquifers below land surface ranges from 20 to $300 \mathrm{ft}$. Aquifer hydraulic conductivities were computed from specific-capacity data recorded on drillers logs and from MDNR and U.S. Geological Survey aquifer-test data. Hydraulic conductivities range from about 10 to $750 \mathrm{ft} / \mathrm{d}$ (feet per day). Aquifer transmissivities typically range between 500 and $3,000 \mathrm{ft}^{2} / \mathrm{d}$ (feet squared per day). Irrigation-well yields of 1,000 gal/min (gallons per minute) are common for most of the aquifers.

Geologic logs indicate that the surficial aquifer coalesces with confined aquifers in zones $A, C, D$, and $F$ in various parts of the study area (Delin, 1988). Greater than 50 percent of the known areal extent of confined aquifers in zones $\mathrm{A}$ through $\mathrm{E}$ is within the study area. Aquifers in zone $\mathrm{F}$, however, are located primarily between Starbuck and Sunberg, southwest of the BrootenBelgrade sand plain, and south of New London. Geologic logs also indicate that several of the confined aquifers may coalesce with each other and with sediments beneath Lakes Minnewaska and Koronis. It was beyond the scope of the study to verify or investigate in detail these areas of apparent aquifer coalescing.

\section{Bedrock Aquifers}

Igneous and metamorphic rocks of Proterozoic (Late Precambrian) age directly underlie drift throughout most of the model area. The rocks consist primarily of granite. Virtually all water is present in fractures and in weathered zones near the top. The rocks generally are dense, having low porosities and permeabilities. Although isolated wells are known to yield as much as $14 \mathrm{gal} / \mathrm{min}$ from these rocks, they are not considered to be a major aquifer in the area. 


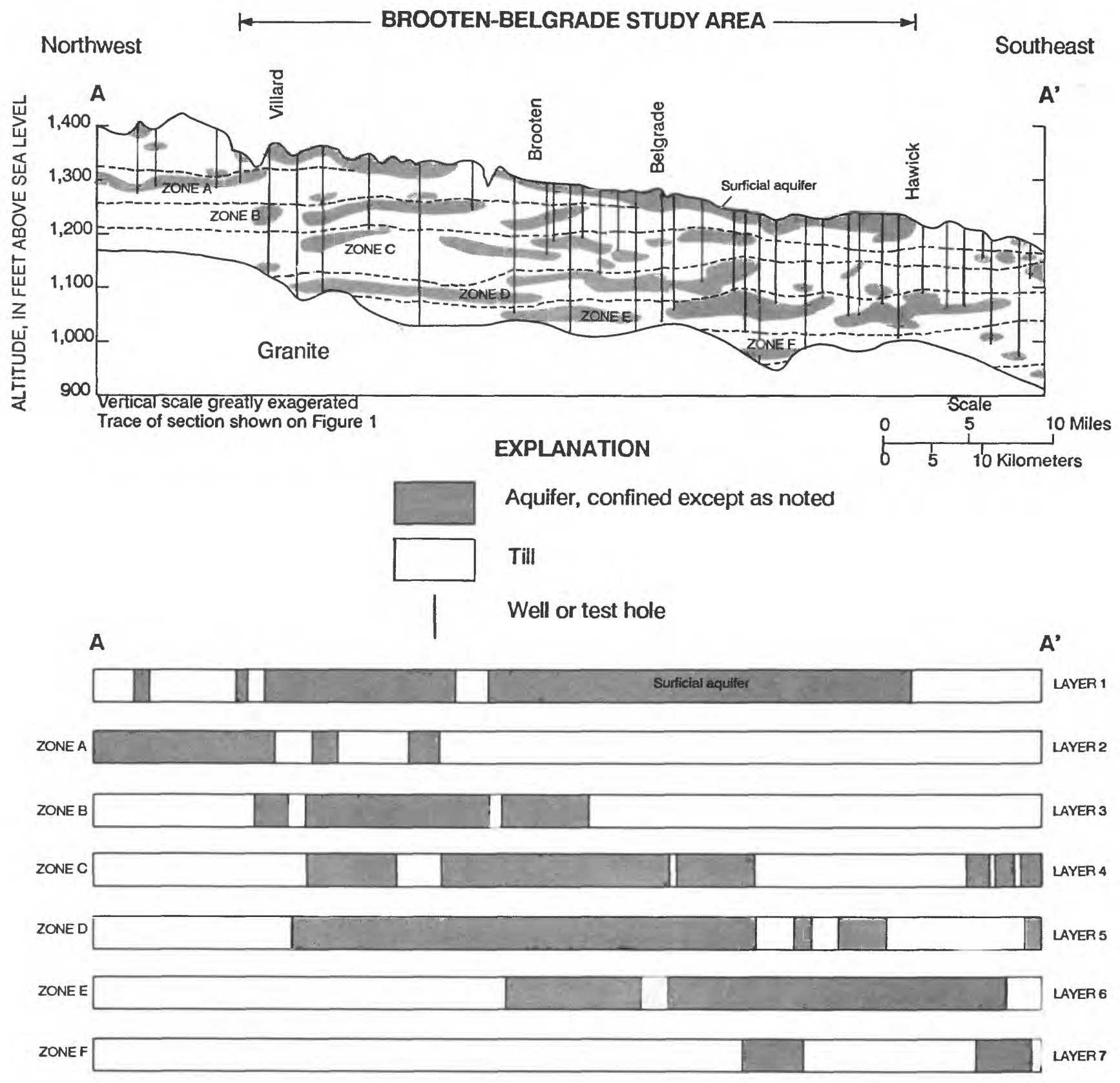

Figure 4.-Hydrogeologic section A-A' showing drift lithology and schematic representation of layering for the model 
Deposits of Cretaceous age overlie the Proterozoic rocks in parts of the area. These discontinuous and generally semi-consolidated shale and sandstone deposits are difficult to differentiate from drift. Wolf (1976) indicated a maximum thickness of Cretaceous deposits in the area of $112 \mathrm{ft}$. Although a few wells are known to yield as much as $150 \mathrm{gal} / \mathrm{min}$ from Cretaceous rocks, the deposits are not considered to be a major aquifer in the modeled area.

\section{Hydrology}

The major source of areal recharge to the ground-water system is precipitation. Recharge to the ground-water system is greater in areas where the surficial aquifer is present. Ground-water levels commonly rise in spring because recharge from snowmelt and spring rain is greater than discharge. Conversely, ground-water levels generally decline in summer because discharge by evapotranspiration exceeds recharge. Areal recharge sometimes occurs in the fall, depending on amounts of rainfall, runoff, and evapotranspiration.

Ground-water movement in the surficial and confined aquifers is mainly horizontal from recharge areas underlying uplands to discharge areas along streams. Lateral hydraulic gradients in the aquifer zones range from about 2 to 10 feet per mile. The head in each of the confined aquifers in the modeled area generally decreases with depth, indicating downward movement. This downward vertical movement occurs as slow leakage through till confining layers. Water-level data from four well nests indicate that heads in the surficial aquifer range from 0.5 to $11.0 \mathrm{ft}$ above heads in the confined aquifers. Leakage rates through till of 0.06 to $1.60 \mathrm{in} / \mathrm{yr}$ (inches per year) were computed at nine sites in the area using a form of Darcy's Law. The methodology used to compute leakage rates through till is described by Delin (1988).

Where confined and surficial aquifers coalesce, ground water can move directly from one aquifer to the other in response to natural or man-made stresses. Potentiometric-surface elevations for the confined aquifers in these areas generally are greater than water-table elevations in the adjoining surficial aquifer. Consequently, ground water generally moves under a natural head gradient from confined aquifers into the surficial aquifer where they coalesce.

Ground-water discharges naturally from the surficial and confined aquifers to streams, lakes, wetlands, and by evapotranspiration. Ground-water discharges artificially to pumping wells. Five well nests located near rivers indicate that heads in these discharge areas are between 0.3 and $11.0 \mathrm{ft}$ higher in the confined aquifers than in the surficial aquifer. Ground water from several of the confined aquifers is known to discharge to springs around Lake Minnewaska. Ground-water discharge from springs also probably occurs along the Sauk River.

Water levels in the surficial and confined aquifers fluctuate in response to seasonal variations in recharge and discharge. Pumpage, evapotranspiration, soil moisture, vegetation type, precipitation, and runoff cause waterlevel fluctuations. Water levels in wells completed in the surficial and confined aquifers generally fluctuate 2 to $5 \mathrm{ft}$ annually (Delin, 1988). Water-level fluctuations in the vicinity of a high-capacity pumping 
well, however, are greater for confined aquifers compared to surficial aquifers. Water levels in confined and surficial aquifers generally recover to pre-pumping levels following each irrigation season. Hydrogeologic data suggest that the ground-water levels fluctuate in response to seasonal variations in recharge and discharge around mean water levels that remain relatively constant in time - - that is, the ground-water system is in dynamic equilibrium. Long-term hydrographs from regions surrounding the study area suggest that winter water levels from a given year represent long-term steady-state conditions. Hydrology of the glacial-drift system is described in greater detail by Delin (1988).

\section{SIMULATION OF EFFECTS OF GROUND-WATER DEVELOPMENT}

As part of the primary objective of estimating the effects of groundwater development on water levels in the study area, the flow of water in the drift system was evaluated. The ground-water system is too complex to be analyzed by analytical methods alone. Consequently, a numerical model was constructed as a conceptual tool to help evaluate flow in the drift-aquifer system and to determine the effects of hypothetical pumping and climatic conditions on water levels and on exchange of water between aquifers and streams.

Objectives of the model simulations were to determine (1) the hydraulic connection between the drift aquifers and (2) the effects of drought and of hypothetical increases in ground-water development on ground-water levels and on streamflow.

\section{Model Description}

The computer code of McDonald and Harbaugh (1984) was used to simulate the ground-water-flow system in three dimensions. The model program uses finite-difference methods to obtain a solution to the partial-differential equation of ground-water flow in three dimensions as given below:

$$
\frac{\partial}{\partial x}\left[K_{x x} \frac{\partial h}{\partial x}\right]+\frac{\partial}{\partial y}\left[K_{y y} \frac{\partial h}{\partial y}\right]+\frac{\partial}{\partial z}\left[K_{z z} \frac{\partial h}{\partial z}\right]-W=S_{s}\left[\frac{\partial h}{\partial t}\right],
$$

where

$x, y$, and $z$ are cartesian coordinates aligned along major axes of hydraulic conductivity, $\mathrm{K}_{\mathrm{xx}}, \mathrm{K}_{\mathrm{yy}}, \mathrm{K}_{\mathrm{zz}}$, $[\mathrm{L} / \mathrm{T}]$;

$\mathrm{h}$ is the head [L];

$W$ is a volumetric flux per unit volume and represents sources and/or sinks of water $\left[\mathrm{T}^{-1}\right]$;

$\mathrm{S}_{\mathrm{S}}$ is the specific storage of the porous material $\left[\mathrm{L}^{-1}\right]$; and

$t$ is time $[\mathrm{T}]$.

Solutions to this partial-differential equation were computed using the strongly implicit procedure. 


\section{Mode1 As sumptions}

A conceptual model of ground-water flow in the aquifer system was developed prior to constructing the digital model. The conceptual model consists of simplifying assumptions for the geometry and hydrologic properties used to simulate ground-water flow with the model. These assumptions are necessary because the actual ground-water system is too complex to simulate in every detail. Major simplifying assumptions of the conceptual model are as follows:

(1) Ground-water flow in the drift aquifers is primarily horizontal and flow in the till confining units separating them is primarily vertical; based on available water-level data;

(2) The confining units and confined aquifers within each aquifer zone simulated are continuous, homogeneous, and isotropic;

(3) Because accurate field data are lacking, streambeds are assumed to be $1 \mathrm{ft}$ thick and composed of material having lower hydraulic conductivity than the aquifers;

(4) Minor streams and ditches are insignificant discharge areas for the ground-water system and may be ignored;

(5) Areal recharge to the water table is from precipitation;

(6) Where till is present at land surface, vertical leakage through the till is constant and does not fluctuate seasonally;

(7) The rate of evapotranspiration declines linearly to zero at a depth of $5 \mathrm{ft}$ below land surface; and

(8) Ground water withdrawn for irrigation is consumed by evapotranspiration and, therefore, return flow to the aquifer system is negligible.

\section{Model Representation of Aquifer System}

The drift consists of beds of high permeability material (aquifers) embedded in till. The drift was divided into seven layers (table 1 and fig. 4), with layer one (top layer) representing the surficial aquifer. Although several confined aquifers occur in each of the aquifer zones (fig. 4), the aquifers in each zone were necessarily simulated as one confined aquifer. To accurately simulate ground-water flow in each confined aquifer, a model consisting of many more model layers would be necessary. This was beyond the scope of the study. Vertical flow in the ground-water system was simulated implicitly by allowing leakage between mode1 layers.

The modeled area was subdivided into blocks by a uniform grid of 59 rows and 43 columns (fig. 2). The center of each grid block (cell) is referred to as a node. Each grid block is 1 mile on a side; thus, each cell covers $1 \mathrm{mi}^{2}$. 
Table 1.--Relation between model layers and hydrogeologic units

Vertical leakage

between

Model layer
Hydrogeologic unit

(1)
1

$$
1-2
$$

2

$2-3$

3

$3-4$

4

5

$5-6$

6

$6-7$
Surficial aquifer

Till confining unit

Confined aquifers in zone A

Ti11 confining unit

Confined aquifers in zone B

Till confining unit

Confined aquifers in zone $\mathrm{C}$

Till confining unit

Confined aquifers in zone D

Til1 confining unit

Confined aquifers in zone E

Till confining unit

Confined aquifers in zone $F$

(1) Each till confining unit shown in this column is part of one till unit. They are not separate units. 


\section{Boundary Conditions}

The specification of appropriate boundary conditions is an essential part of accurate simulation of the ground-water-flow system. The natural (physical) hydrologic boundaries of the ground-water system were selected as model boundaries where possible. Selection of the boundary conditions, however, involves considerable simplification of actual hydrogeologic conditions.

Modeled boundaries were extended beyond the Brooten-Belgrade sand-plain study area to include natural, regional hydrologic boundaries that encompass the area. These boundaries primarily represent lakes, wetlands, and perennial streams (fig. 5). Heads in these water bodies remain relatively constant in time and, therefore, were simulated as constant-head boundaries in layer one of the model (fig. 5). The value of head for each constant-head node was based on heads estimated from lake, wetland, and stream elevations recorded on U.S. Geological Survey 7 1/2-minute quadrangle maps. Where the surficial aquifer extends beyond the model boundary to the northwest (fig. 6), the model computed ground-water flow into or out of the modeled area using heads specified at the constant-head nodes. Data indicates that heads in confined aquifers increase with depth below rivers in the area (Delin, 1988), indicating vertical flow upward. Consequently, no-flow boundaries were specified in layers 2 through 7 beneath the model boundary. Many of the confined aquifers, however, do not extend past the model boundary.

Ground-water divides also form about 3 percent of the regional model boundary (fig. 5). Although ground-water divides are not ideal model boundaries, because they can move in time, this small percentage was considered insignificant in light of the regional nature of the model. No-flow boundary conditions were specified in all layers where ground-water divides are present along the model boundary.

Because the hydraulic conductivity of till in the area is two to eight orders of magnitude smaller than the hydraulic conductivity of glacial-drift aquifers, till was simulated as a no-flow boundary in the model. Thus, the lateral interface between aquifer and till represents no-flow boundaries for aquifers in each layer (figs. 7-12). Although some horizontal flow of ground water undoubtedly occurs through till, this flow is insignificant compared to the magnitude of flow through the drift aquifers. Because of the no-flow condition at the boundary of each simulated aquifer, aquifers within each aquifer zone generally are independent of each other. Simulation of flow between closely spaced aquifers within a zone is described in the next section of the report.

Potentiometric-surface data indicate that flow beneath aquifers in zone $F$ (layer 7) is minimal. It is the lowermost aquifer zone identified in the area and very little drift is present between this zone and the underlying granite, which does not transmit water readily. Consequently, the base of layer 7 was simulated as a no-flow boundary. A no-flow boundary was specified at points where the surficial aquifer extends as narrow channels east to the Sauk River (fig. 6). Ground-water flow in these areas is primarily toward streams with minimal flow downvalley. 


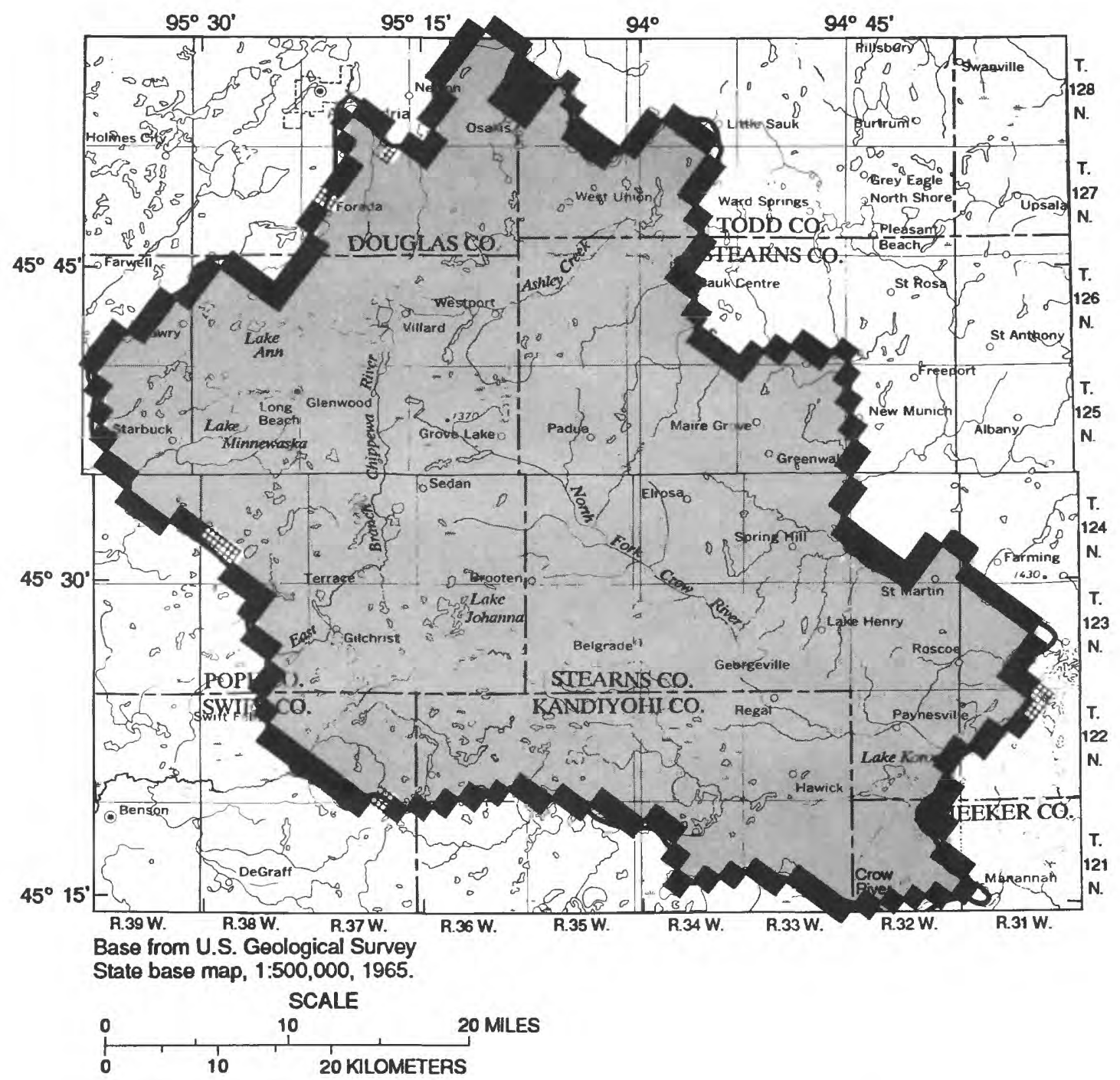

\section{EXPLANATION}

Area in which ground-water flow was simulated by the model in the aquifers

Constant-head boundary in uppermost model layer (stream)

No-flow boundary in uppermost model layer (ground-water divide) 


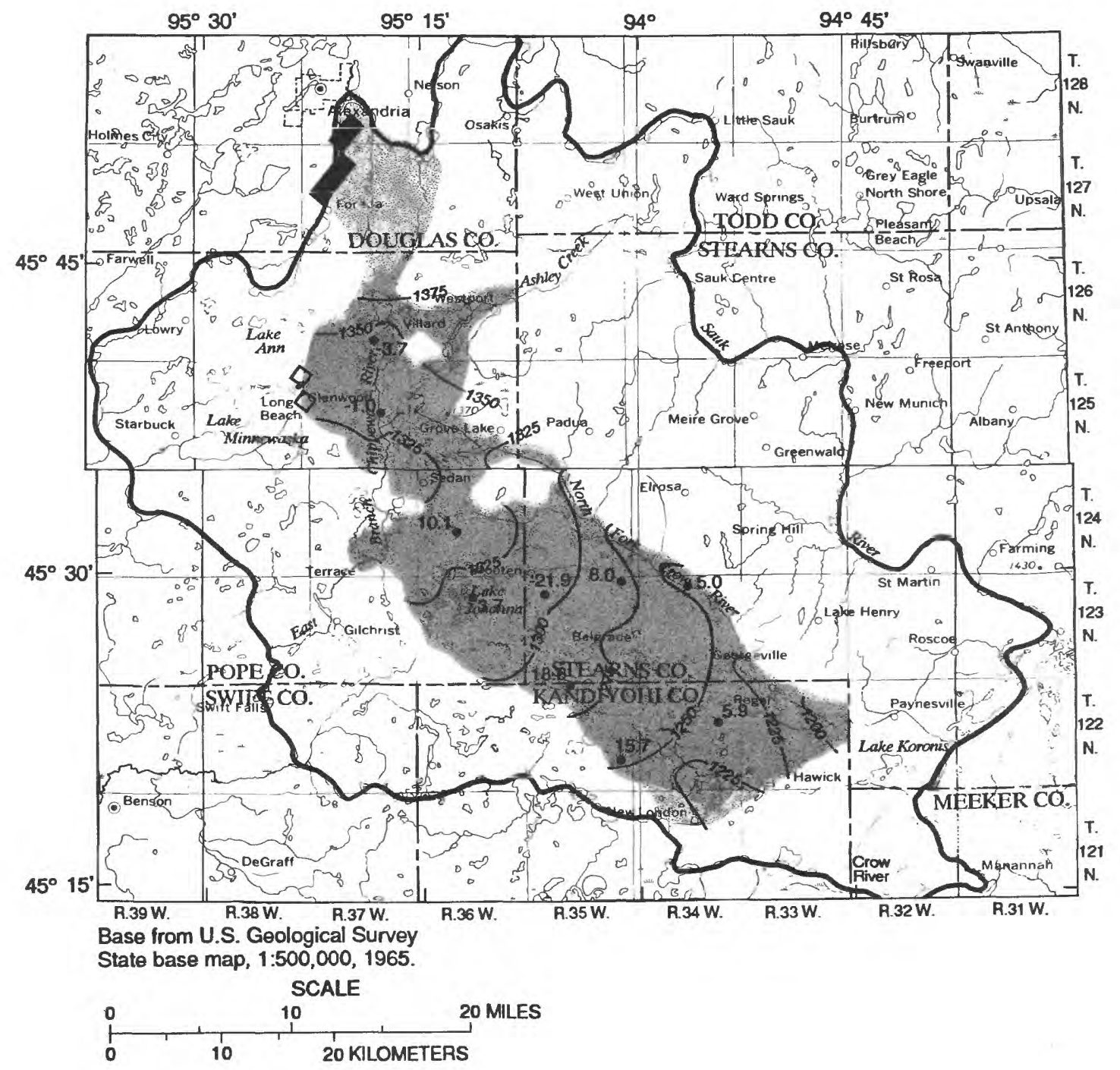

\section{EXPLANATION}

Area in which ground-water flow was simulated (aquifer)

Study area

Hydrological boundary
Constant-head boundary (stream)
$\diamond \quad$ Drain boundary (spring)
$-1200-\quad \begin{aligned} & \text { Model-computed potentiometric contour. } \\ & \text { Interval } 25 \text { feet. Datum is sea level. }\end{aligned}$
$-1.0 \quad$ Data point and deviation from measured water
level, in feet

Figure 6.--Boundary conditions and differences between model-computed water levels and water levels measured in 1985 in the surficial aquifer, layer 1 


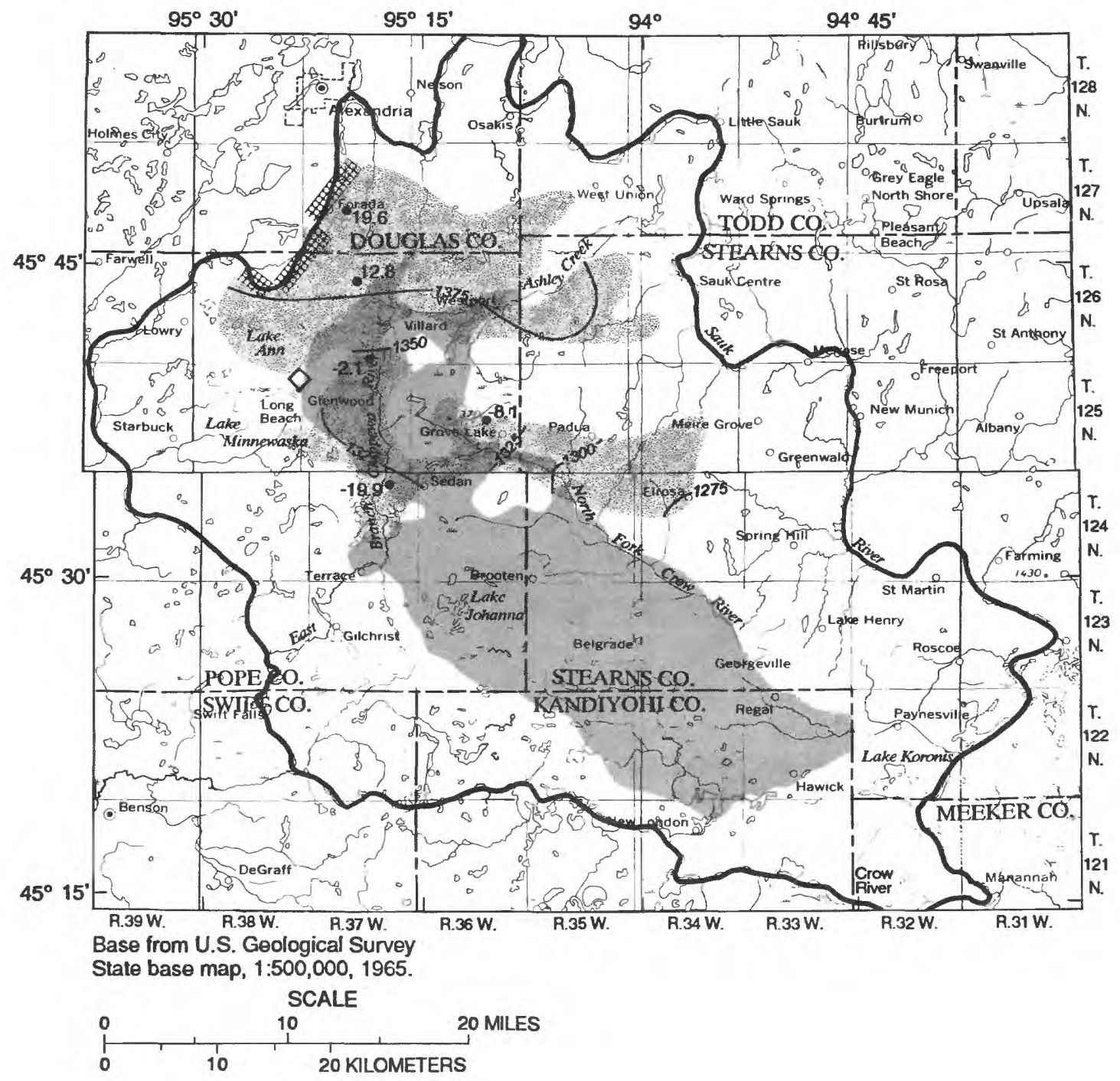

\section{EXPLANATION}

Area in which ground-water flow was simulated (aquifer)

Study area

- Hydrological boundary

No-flow boundary (beneath stream)

$\diamond \quad$ Drain boundary (spring)

-7375- Model-computed potentiometric contour. Interval 25 feet. Datum is sea level.

-2.1 Data point and deviation from measured water level, in feet

Figure 7.-Boundary conditions. and differences between model-computed water levels and water levels meaured in $\mathbf{1 9 8 5}$ in zone A, layer 2 


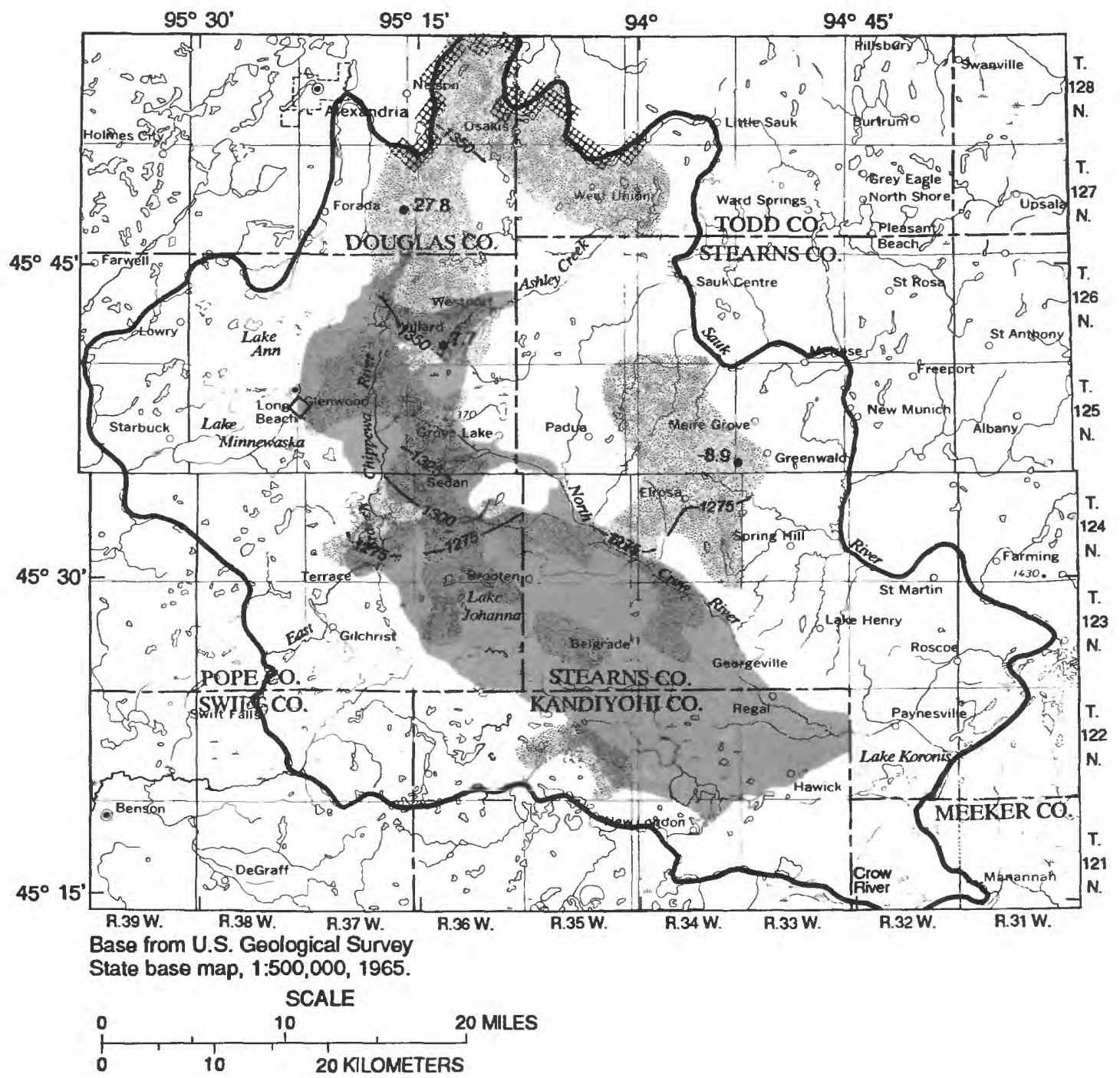

\section{EXPLANATION}

Area in which ground-water flow was simulated (aquifer)

Study area

Hydrological boundary

No-flow boundary (beneath stream)

$\diamond \quad$ Drain boundary (spring)

-1350- Model-computed potentiometric contour. Interval 25 feet. Datum is sea level.

27.8. Data point and deviation from measured water level, in feet 
A head-dependent-flux boundary was specified where the confined aquifers coalesce with deposits beneath Lakes Minnewaska and Koronis (fig. 13). The head-dependent-flux boundary allows leakage into or out of the modeled area based on the hydraulic conductivity of the lake-bed material (10 ft/d) and head in the lake. Franke and others (1984) give a detailed description of the properties of each type of boundary condition.

\section{Simulation of Aquifers and Confining Units}

The complex geometries that define the known areal extent of confined aquifers in each zone (figs. 6-12) could not be duplicated exactly with the regional ground-water-flow model. The boundary of the surficial aquifer (fig. 6) was modified slightly from earlier publications (Van Voast, 1971; Wolf, 1976) and reflects current geologic information. The surficial aquifer extends east to the Sauk River along narrow channels both east of Westport and east of Paynesville. Flow in these narrow channels was not simulated with the model. Ground-water flow in most of the small, isolated sand and gravel deposits included within a given confined aquifer (Delin, 1988) also was not simulated with the model. Simulation of flow in these deposits would require a much more detailed finite-difference grid and layering scheme, which is beyond the scope of this modeling effort. Flow in nearly all the larger, isolated, confined sand and gravel deposits was simulated, however. In situations where larger sand and gravel deposits are separated by a relatively narrow section of till, such as in layer 4 south of Glenwood (fig. 9), horizontal flow was simulated through the till. A reduced transmissivity was specified in these areas to represent the effects of flow through till, compared to flow through a sand and gravel aquifer. This was considered necessary to improve the accuracy of flow simulation in the isolated deposits and is justifiable considering the lack of detailed geologic data.

Transmissivity of the confined aquifers in each layer was assigned by overlaying the model grid on the transmissivity map for that aquifer zone (Delin, 1988) and averaging the transmissivity within each cell. Confinedaquifer transmissivities were mapped based on the product of aquifer thickness and mean hydraulic conductivity. In areas where specific capacity or aquifertest data were available, hydraulic-conductivity values were adjusted accordingly. Because the seven aquifers simulated are areally discontinuous, some areas in each layer represent till. Horizontal ground-water flow was not simulated in the till, however.

Vertical flow through the till confining units was simulated in the model by assigning a vertical-leakage coefficient between model layers (table 1 , fig. 4). This coefficient was calculated by dividing the estimated till thickness for each model cell into the mean vertical hydraulic conductivity for till in the study area, which is $0.40 \mathrm{ft} / \mathrm{d}$ (Delin, 1988). Calculation of the vertical leakage coefficient does not include the thickness of thin discontinuous sand units that occur in till. In areas where geologic logs indicate that drift aquifers coalesce, a vertical hydraulic conductivity of $100 \mathrm{ft} / \mathrm{d}$ was used in computing vertical leakage. This value represents the approximate vertical hydraulic conductivity for drift aquifers in the area. 


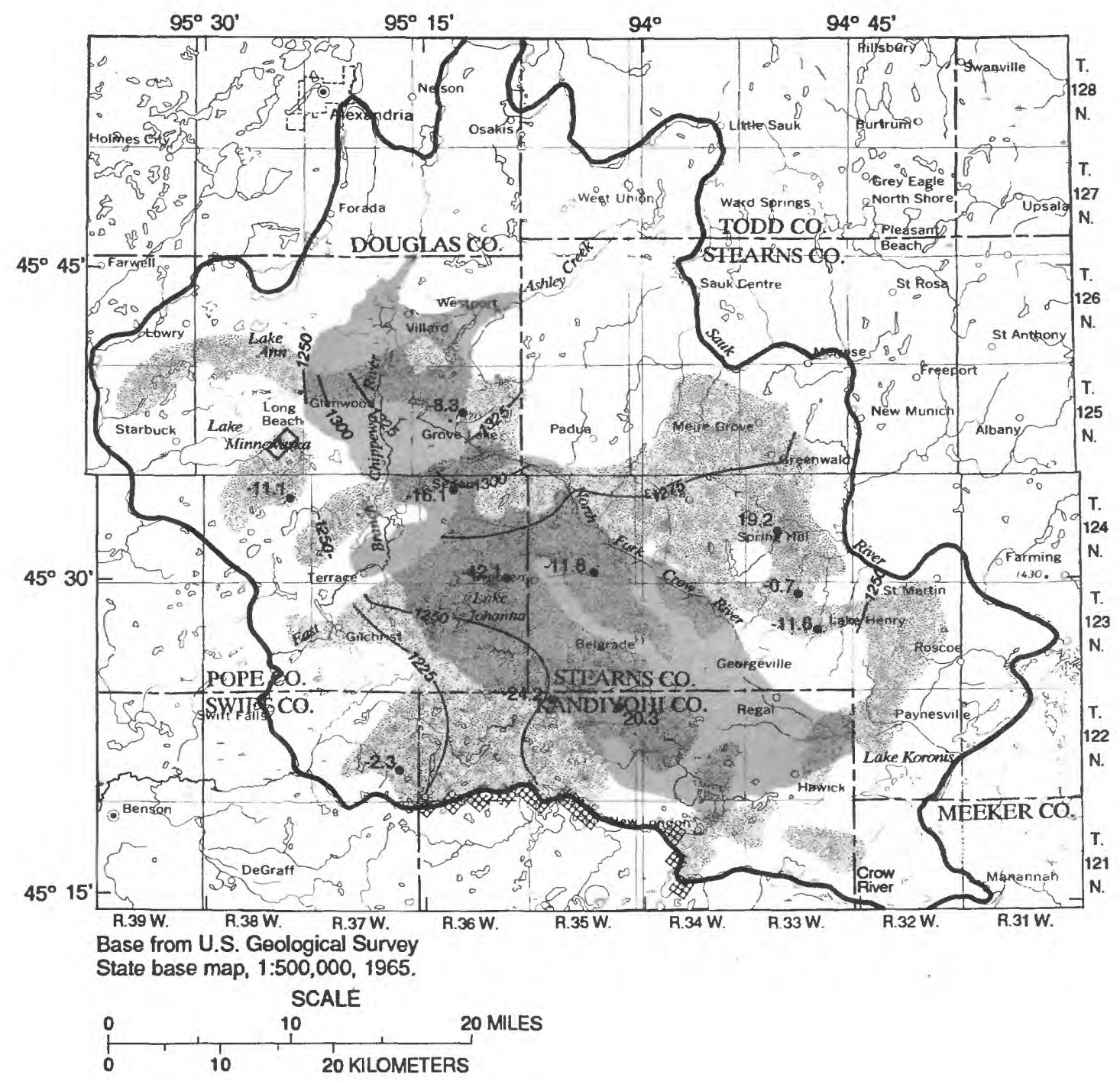

\section{EXPLANATION}

Area in which ground-water flow was simulated (aquifer)

Study area

Hydrological boundary

No-flow boundary (beneath stream)

$\diamond \quad$ Drain boundary (spring)

-1275- Model-computed potentiometric contour. Interval 25 and 50 feet. Datum is sea level.

-2.3. Data point and deviation from measured water level, in feet 


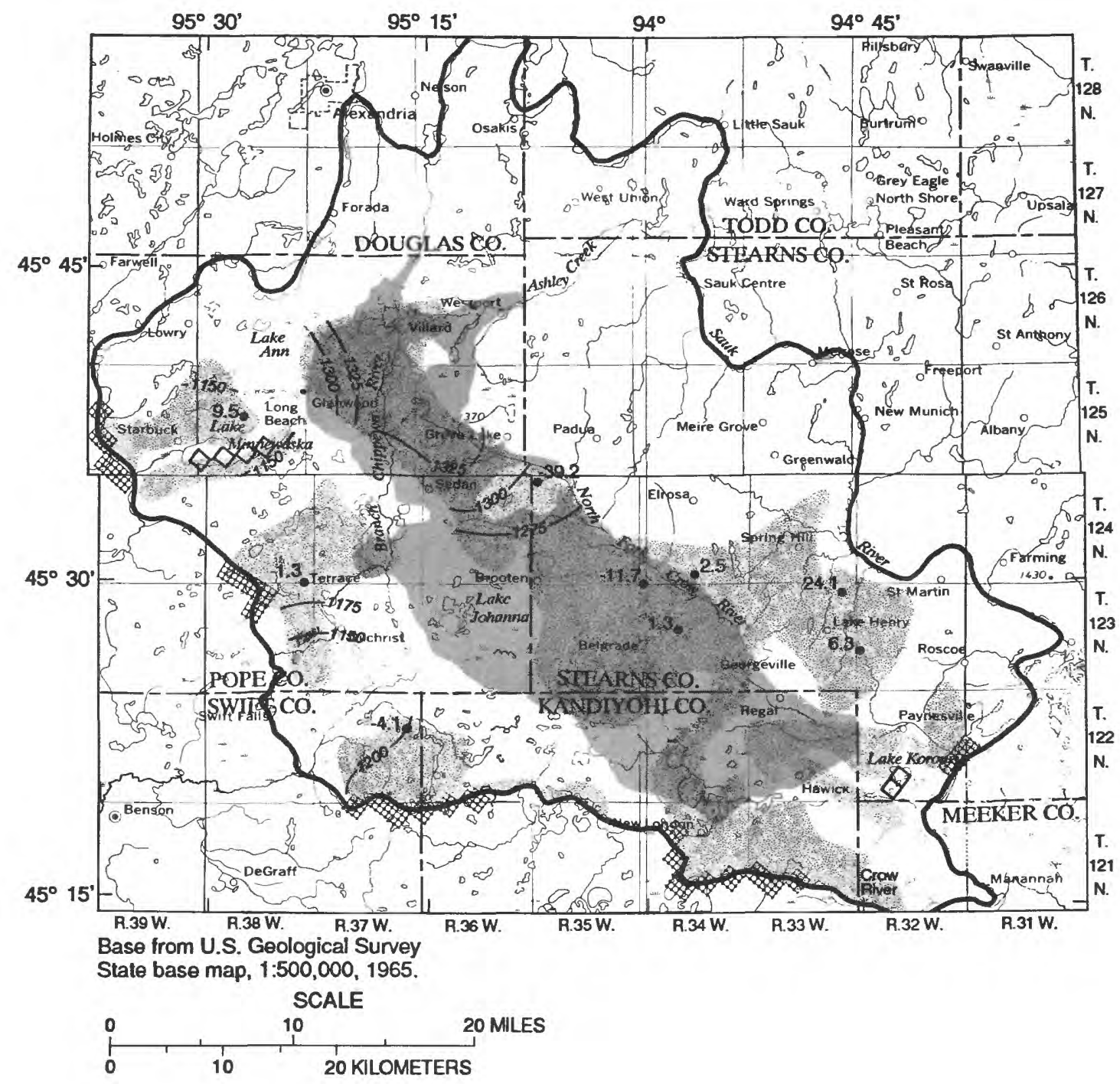

\section{EXPLANATION}

Area in which ground-water flow was simulated
(aquifer)
Study area
Hydrological boundary
No-flow boundary (beneath stream)
Head-dependent flux boundary (lake)
6.3. $\quad \begin{aligned} & \text { Model-computed potentiometric contour. } \\ & \text { Interval } 25 \text { feet. Datum is sea level. }\end{aligned}$
Data point and deviation from measured water
level, in feet

Figure 10.-Boundary conditions and differences between model-computed water levels and water levels measured in 1985 in zone D, layer 5 


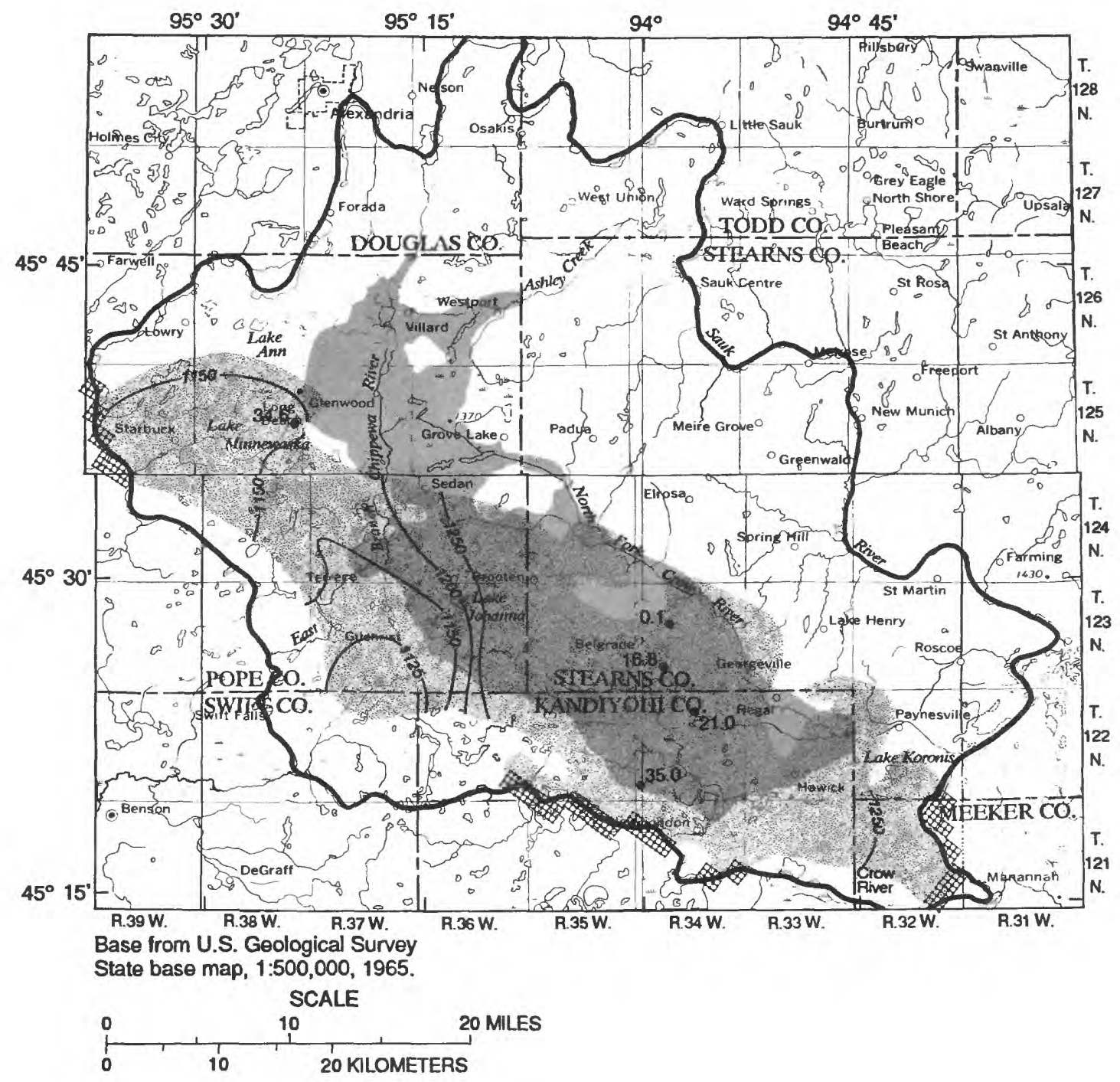

\section{EXPLANATION}

Area in which ground-water flow was simulated (aquifer)

Study area

Hydrological boundary

No-flow boundary (beneath stream)

$-1200-$ Model-computed potentiometric contour. Interval $\mathbf{2 5}$ and $\mathbf{5 0}$ feet. Datum is sea level.

35.0. Data point and deviation from measured water level, in feet

Figure 11.-Boundary conditions and differences between model-computed water levels and water levels measured in 1985 in zone E, layer 6 


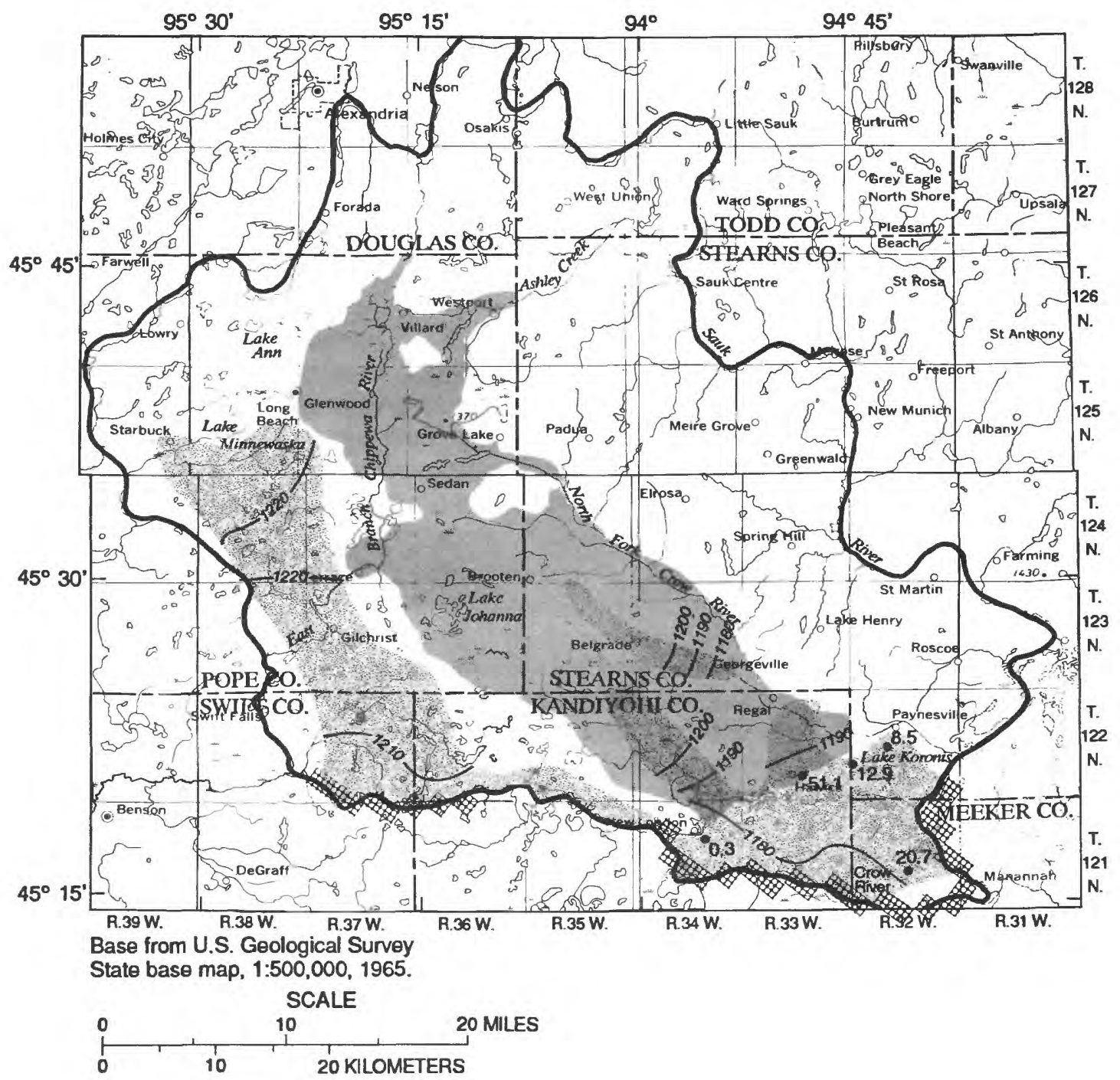

\section{EXPLANATION}

Area in which ground-water flow was simulated (aquifer)

$\begin{array}{cl} & \text { Study area } \\ \text { Hydrological boundary } \\ \text { No-flow boundary (beneath stream) } \\ \text {-1200- Model-computed potentiometric contour. } \\ \text { Interval } 10 \text { feet. Datum is sea level. } \\ \text { Data point and deviation from measured water } \\ \text { level, in feet }\end{array}$

Figure 12.-Boundary conditions and differences between model-computed water levels and water levels measured in 1985 in zone F, layer 7 
Where an inactive cell (no horizontal flow) representing till is located in a model layer between active cells in overlying and underlying model layers, the model did not simulate vertical leakage between layers. This inaccurate representation of leakage in the aquifer system introduces a possible error in the model results. Given the large thickness of till confining units and the relatively low hydraulic gradient through them, a minimal error is expected. Model-computed vertical leakage was zero for many cells overlying an active cell in the underlying model layer. For future model simulations of complex drift systems, however, it may be advisable to simulate horizontal flow through the till confining units. Vertical leakage between model layers would be computed for all cells, thus avoiding potential errors resulting from inaccurate simulation of vertical leakage.

\section{Simulation of Streams, Ground-Water Withdrawals, Evapotranspiration, and Areal Recharge}

Ground-water discharge from the surficial aquifer to the East Branch Chippewa and North Fork Crow rivers is significant. The larger lakes also are areas of ground-water discharge. These rivers and lakes were simulated as head-dependent-flux cells primarily in layer one of the model (fig. 14). Many lakes southwest of the study area and parts of the East Branch Chippewa River, however were simulated in layers 2 through 7, depending on which layer was representative of the stratigraphic horizon in which the lake or river is present. Head-dependent-flux cells allow leakage between the aquifer and river based on a specified head in the river and a streambed-leakage coefficient. A streambed-leakage coefficient was calculated for each river cell and is equal to the vertical hydraulic conductivity of the streambed $\left(\mathrm{K}^{\prime}\right)$ divided by its thickness $(\mathrm{m})$ multiplied by the streambed area in that cell. An initial value of 0.1 foot per day per foot was used for the value of $\mathrm{K}^{\prime} / \mathrm{m}$. This value is similar to that used in previous investigations by Larson (1976), Lindholm and others (1980), Soukup and others (1984), and Delin (1986b).

Reported irrigation and municipal-pumpage records were obtained from the 1984 Minnesota Water-Use Database at the MDNR. Additional pumpage not reported to the MDNR was estimated using a technique developed by Horn (1984). MDNR records indicate that pumping for 1984 was about average for the period of record. Total pumpage of $6,012 \mathrm{Mgal} / \mathrm{yr}$ (million gallons per year) was distributed among 322 pumping centers in the 7 model layers. Locations of the pumping centers simulated during steady-state simulations are shown in figures 15 through 21 .

Areal recharge, as used in the model, represents the rate of water reaching the water table. Areal recharge is reduced in areas where ground-water losses to evapotranspiration occur. Consequently, a net recharge value (precipitation minus evapotranspiration) was applied as an estimate of recharge to the ground-water system. This value represents the net amount of water reaching the ground-water system after losses to evapotranspiration. This was done to avoid potential problems inherent to simulating the complex evapotranspiration process with the model code. It is justifiable because ground-water losses to evapotranspiration occur over a relatively small percentage of the modeled area. Separate model runs were made as a comparison between the two methods of simulating areal recharge. Similar model results were computed, further justifying use of the net-recharge method. 


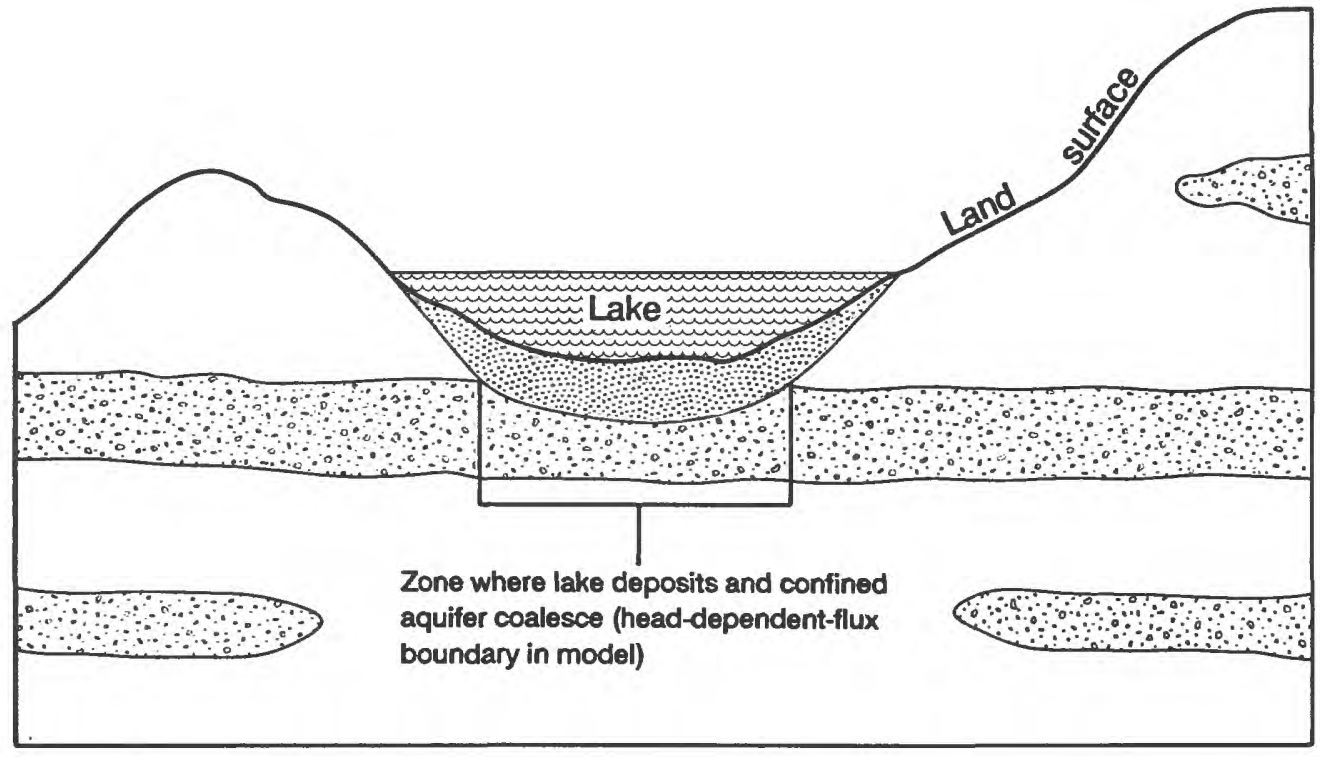

\section{EXPLANATION}

$\therefore$ Confined aquifer

$\square$ Till

Lake deposits

Figure 13.-Conceptualized coalescing of confined aquifers with deposits beneath Lakes Minnewaska and Koronis 


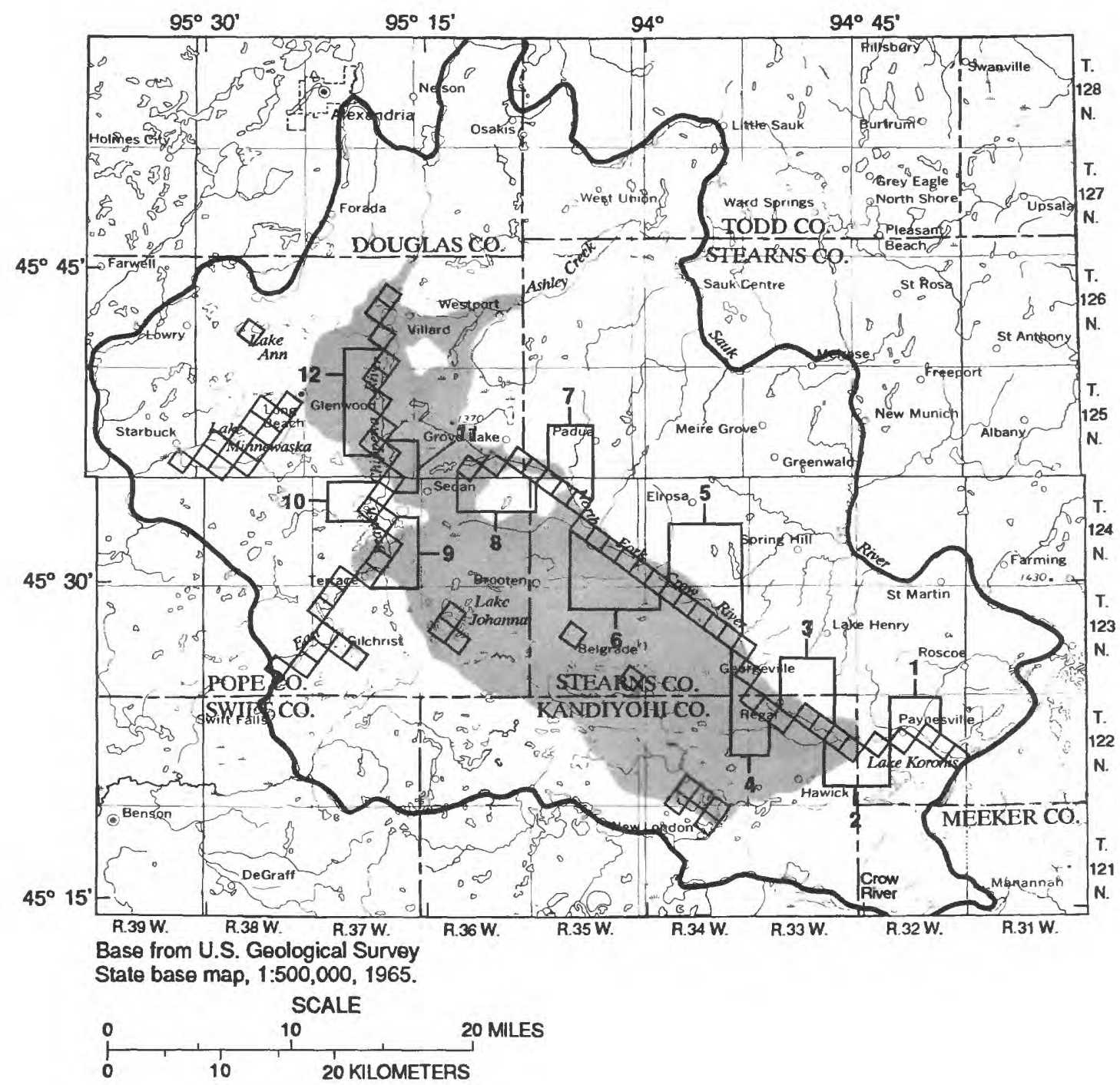

\section{EXPLANATION}

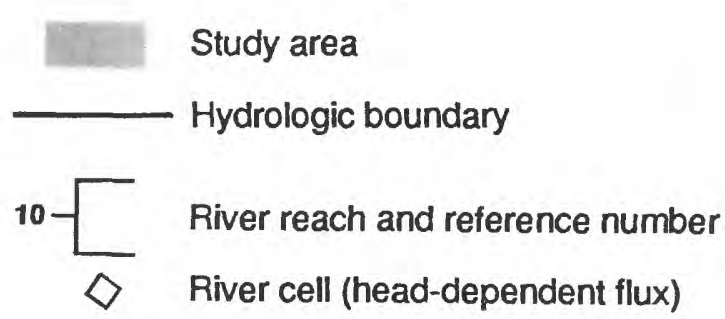

Figure 14.--River cells and river reaches for which ground-water discharge rates were calculated 
Areal recharge rates were calculated in areas where the water table generally is greater than $5 \mathrm{ft}$ below land surface, thus evapotranspiration of ground-water was not considered in these analyses. The value of areal recharge for areas where the surficial aquifer is present was calculated by a standard method of hydrograph analysis described by Rassmussen and Andreason (1959). Application of the method for this study is described by Delin (1988). Hydrograph analyses indicate that recharge to the surficial aquifer during 1982-84 ranged from about 3 to $16 \mathrm{in} / \mathrm{yr}$ and averaged about $10 \mathrm{in} / \mathrm{yr}$. Similar rates were computed for the area by Van Voast (1971); he gave an example of $5.3 \mathrm{in} / \mathrm{yr}$ in his report. An areal recharge rate of $10 \mathrm{in} / \mathrm{yr}$ was specified initially to the surficial aquifer.

Areal recharge to the uppermost confined aquifer also was applied in areas where the surficial aquifer was absent. Recharge rates in these areas can be estimated, as leakage to a confined aquifer, using the following form of Darcy's Law:

where

$$
\mathrm{q}=4,380 \frac{\mathrm{K}^{\prime} \Delta \mathrm{h}}{\mathrm{m}^{\prime}},
$$

$q=1$ leakage through confining bed to confined aquifers, in inches per year;

$\mathrm{K}^{\prime}$ = vertical hydraulic conductivity of confining bed, in feet per day; $\mathrm{m}^{\prime}=$ confining bed thickness, in feet;

$\Delta h=$ difference between head in confined aquifer and in source bed overlying the confining bed, through which leakage occurs, in feet.

Leakage rates to confined aquifers of 0.06 to $1.60 \mathrm{in} / \mathrm{yr}$ were calculated for nine locations in the modeled area. An areal recharge rate of $1.0 \mathrm{in} / \mathrm{yr}$ was applied initially in areas where till is the uppermost unit.

\section{Mode1 Calibration}

The model was calibrated to assure that the hydrologic properties selected were reasonable for simulation of flow in the ground-water system. The model was calibrated for steady-state conditions by comparing measured groundwater levels and estimated ground-water discharge to rivers with corresponding values computed by the model. Transient-state calibration was not done because long-term water-level data have not been collected for confined aquifers in the Brooten-Belgrade area. The calibration procedure consisted of successively adjusting hydrologic-input values until model-computed water levels and ground-water-discharge rates matched field measurements. Adjustments during steady-state calibration centered largely on the vertical hydraulic conductivity of till, hydraulic conductivity of the aquifers, and the areal-recharge rate, which were less well defined than other model input. Because long-term, average water-level data were unavailable, model-computed heads were compared to heads measured in the field during December 1985. Available data in other parts of Minnesota indicate that these heads, measured in winter, approximate equilibrium conditions in the ground-water system. Land-surface elevations for all measured water-level data were estimated to within $5 \mathrm{ft}$. In addition, land-surface elevations typically differ by 20 to $40 \mathrm{ft}$ within 1 cell and locally change by as much as $260 \mathrm{ft}$ in $1 \mathrm{mile}$. Therefore, a considerable amount of error in local model-computed water-levels was expected. 


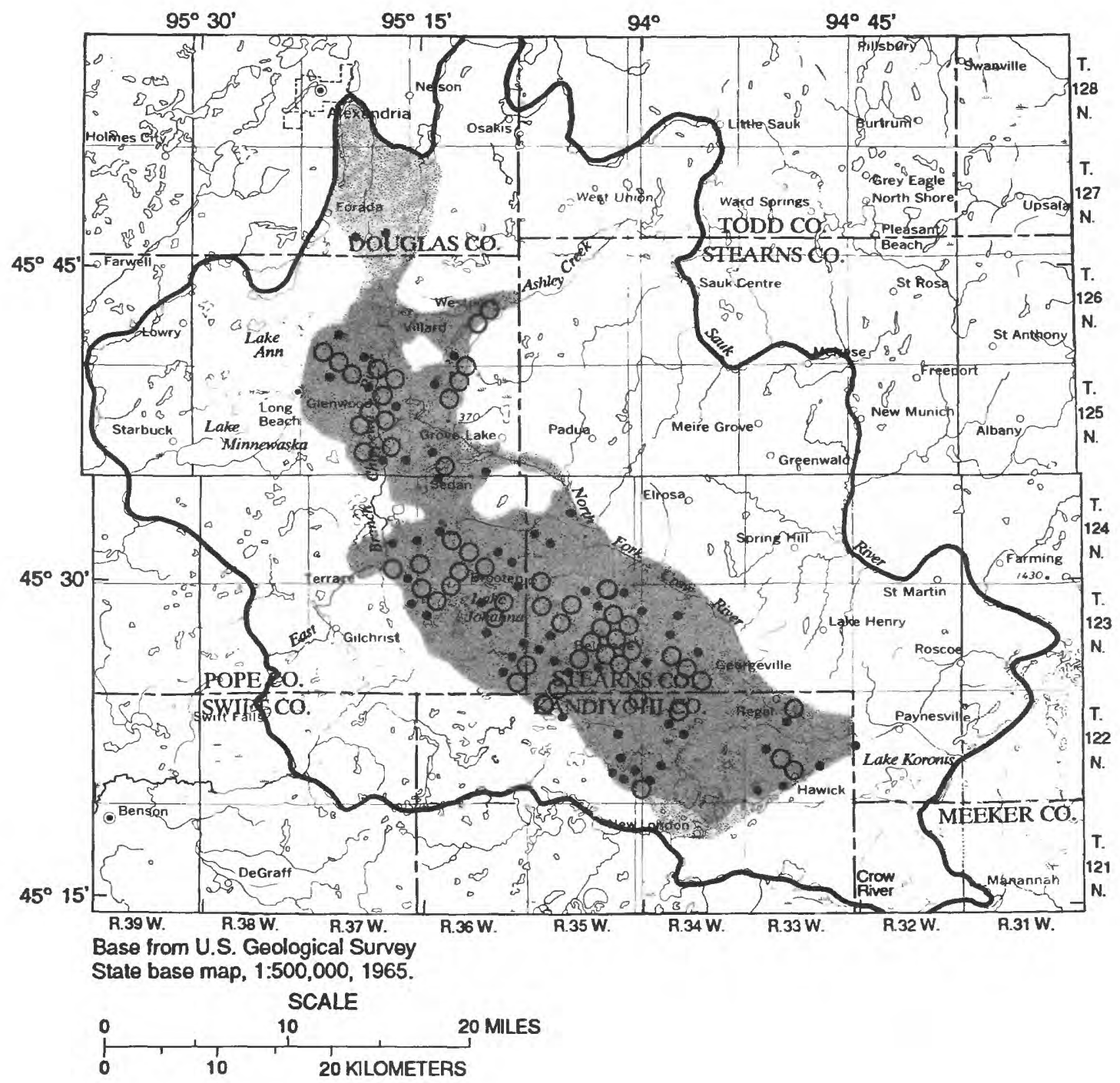

\section{EXPLANATION}

Area in which ground-water flow was simulated (aquifer)

Study area

Hydrological boundary

- Pumped well

O More than one pumped well

Figure 15.-Location of pumped wells simulated in the surficial aquifer, layer 1 


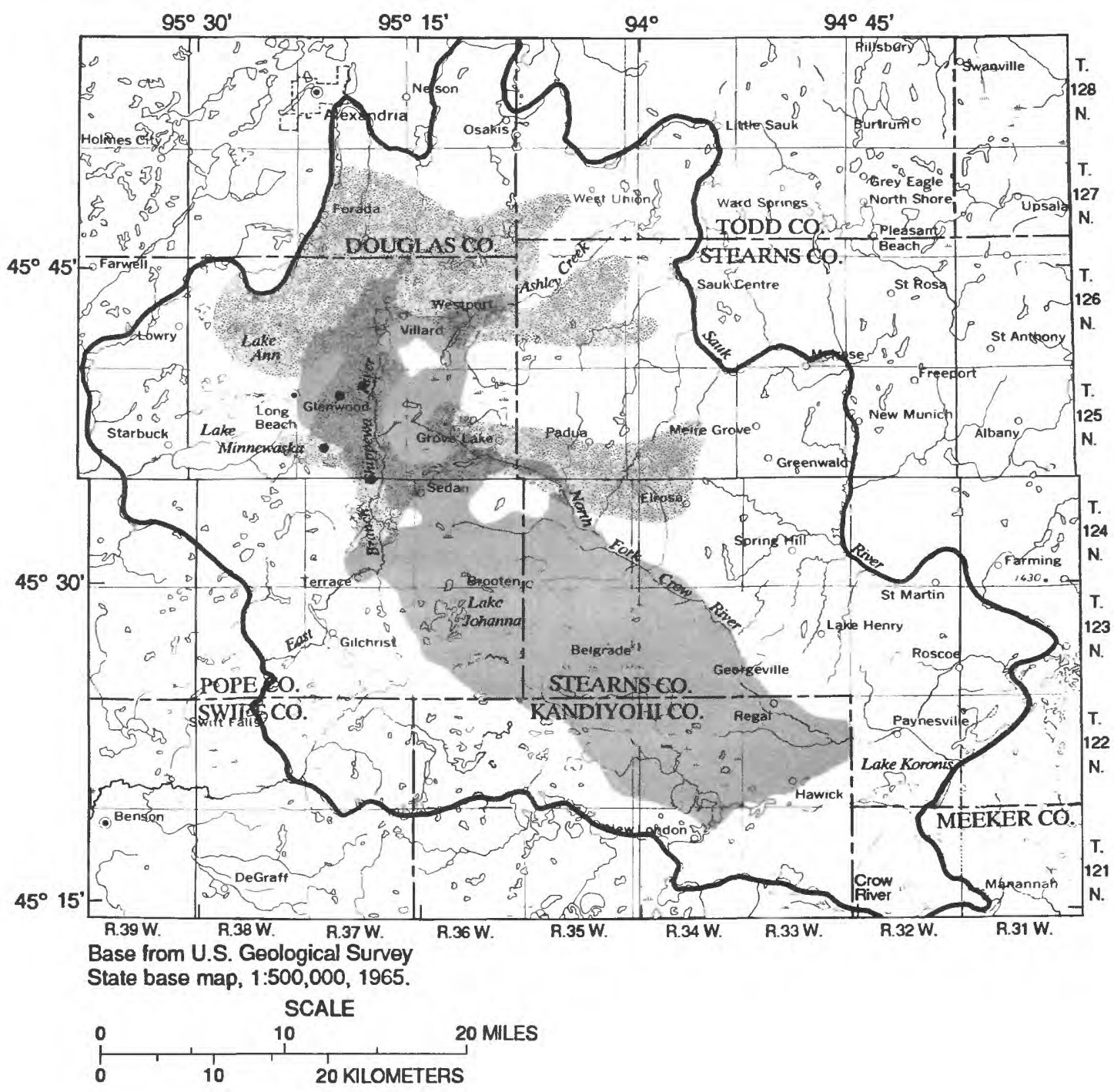

EXPLANATION

Area in which ground-water flow was simulated (aquifer)

Study area

Hydrological boundary

- $\quad$ Pumped well

Figure 16.-Location of pumped wells simulated in zone A, layer 2 


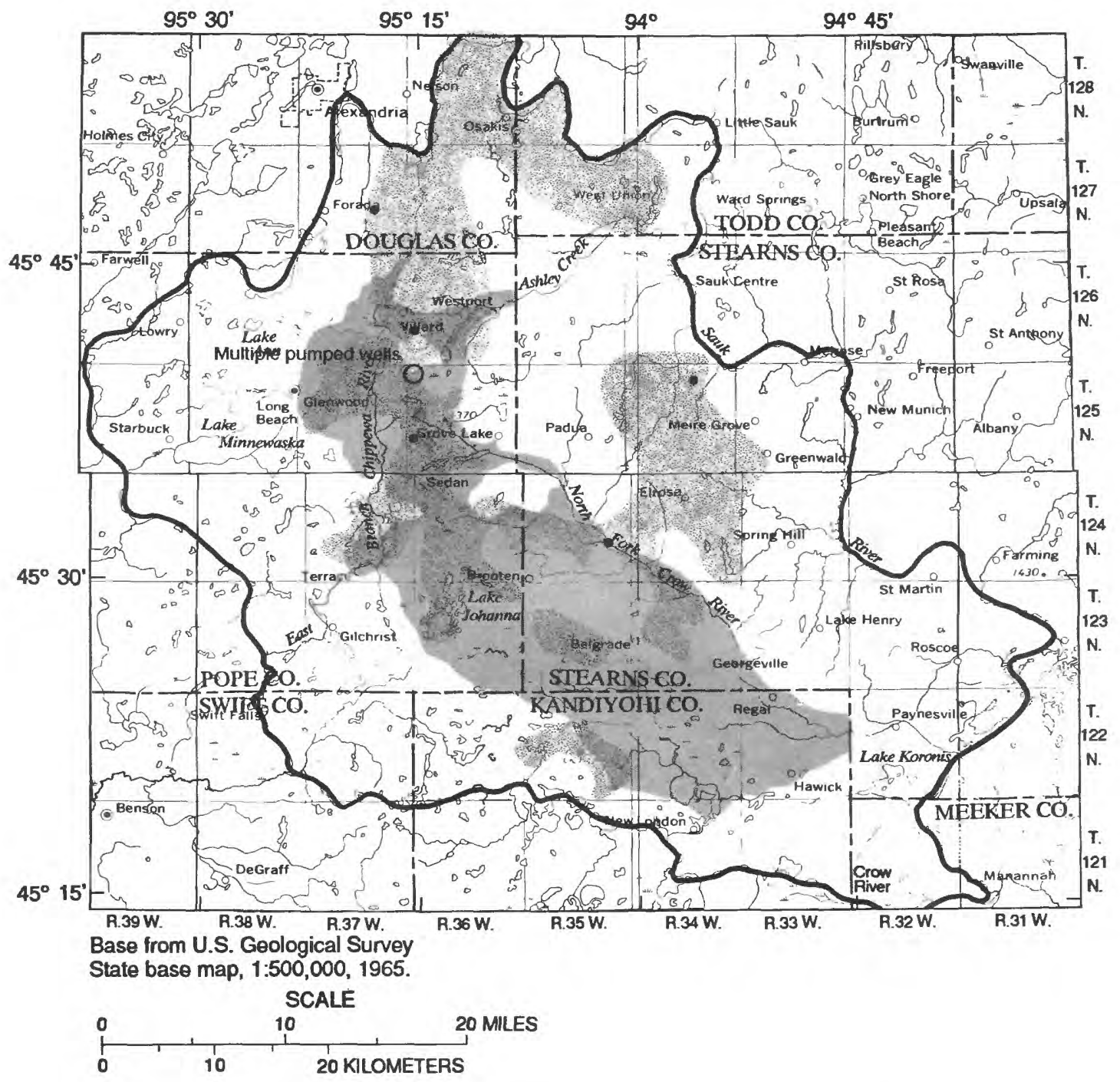

\section{EXPLANATION}

Area in which ground-water flow was simulated (aquifer)

Study area

Hydrological boundary

- Pumped well

Figure 17.-Location of pumped wells simulated in zone B, layer 3 


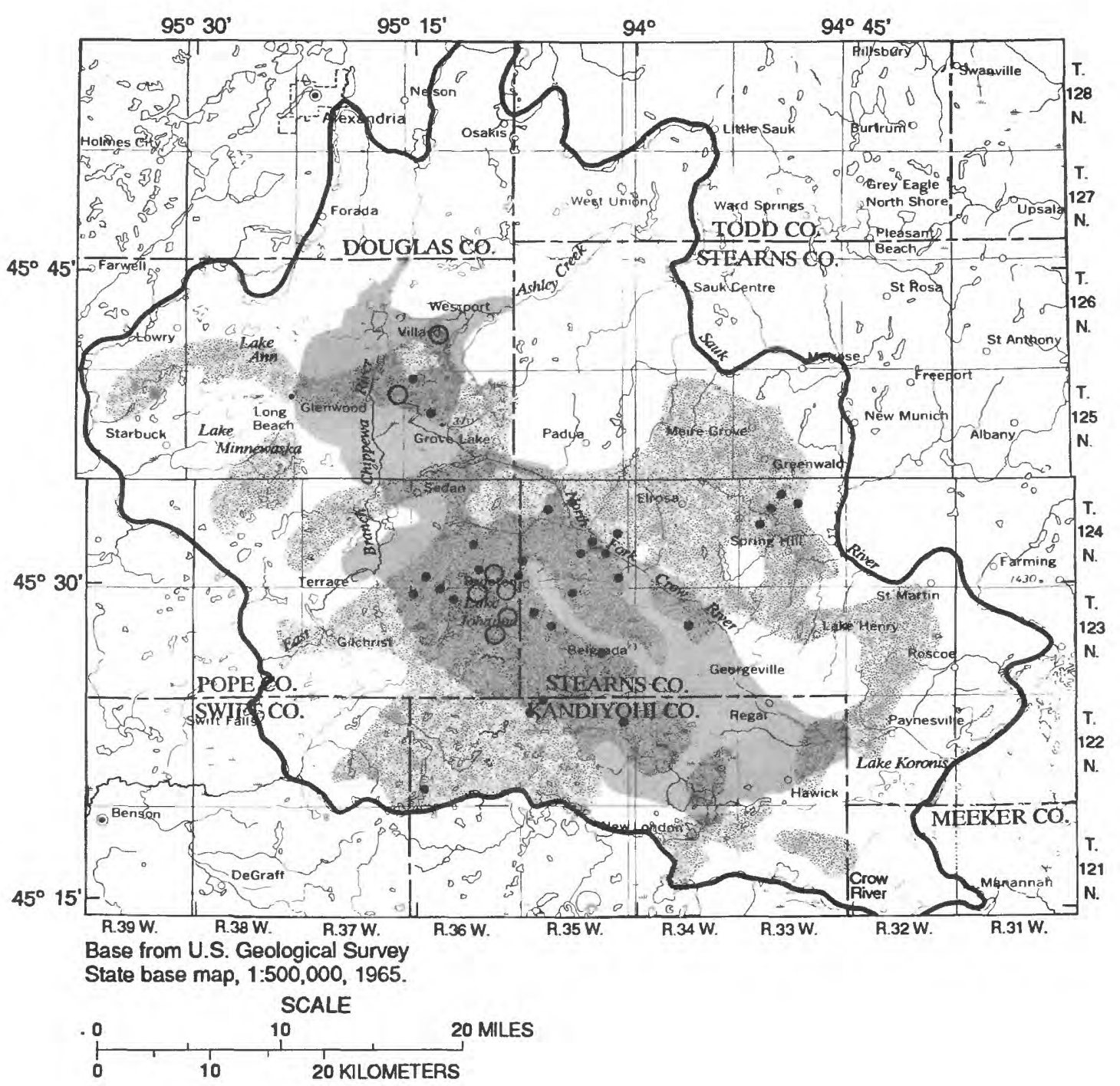

\section{EXPLANATION}

Area in which ground-water flow was simulated (aquifer)

Study area

- Hydrological boundary

- Pumped well

O More than one pumped well

Figure 18.--Location of pumped wells simulated in zone C, layer 4 
The vertical hydraulic conductivity of till between each model layer was varied between $2.5 \times 10^{-7}$ and $2.5 \times 10^{-1} \mathrm{ft} / \mathrm{d}$. During calibration, it became apparent that different vertical hydraulic-conductivity values needed to be assigned between each layer in order to successfully calibrate the model. An order of magnitude change in this input between two model layers resulted in water-level changes of as much as $5 \mathrm{ft}$ in all layers. Varying the vertical hydraulic conductivity of till in the model is justifiable because of the complexity of the glacial drift stratigraphy. For example, the presence of an unidentified, and unsimulated, coalescing of drift aquifers would result in a greatly increased vertical hydraulic conductivity between the aquifers. In addition, aquifer-test data (G.N. Delin, U.S. Geological Survey, written communication, 1987) indicate that the vertical hydraulic conductivity of till ranges from $8.6 \times 10^{-6}$ to $1.8 \mathrm{ft} / \mathrm{d}$. The vertical hydraulic conductivity of till ranged from $1 \times 10^{-6}$ to $1 \times 10^{-1} \mathrm{ft} / \mathrm{d}$ in the final steady-state model run. Values of vertical hydraulic conductivity that exceed $1 \times 10^{-1} \mathrm{ft} / \mathrm{d}$ imply the absence, or the presence of only a very thin layer, of till over a large area.

The hydraulic conductivity of confined aquifers in each aquifer zone was adjusted separately during calibration from 0.1 to 10 times the estimated values. Average hydraulic conductivities for each aquifer zone ranged from 125 to $180 \mathrm{ft} / \mathrm{d}$. The best correspondence between the observed and modelcomputed water levels for five of the seven layers was a slightly higher hydraulic conductivity than the values estimated from geologic and hydraulic data (Delin, 1988). Final hydraulic-conductivity values ranged from 0.8 to 1.9 times the estimated values. These model results indicate that the confined aquifers probably are more continuous and transmissive than available data indicate.

The net areal-recharge value applied to the surficial aquifer was varied uniformly from 1 to $11 \mathrm{in} / \mathrm{yr}$. The best correspondence between the observed and model-computed water levels for the seven model layers was achieved at a rate of $1.8 \mathrm{in} / \mathrm{yr}$. This relatively low model-computed recharge rate, compared to estimated rates shown on page 46, was anticipated because the hydrographs used to estimate net areal recharge were only available in areas where evapotranspiration of ground water is minimal. Thus the rates computed from hydrograph analyses over estimated actual net recharge to the aquifer system. The relatively low recharge rate may indicate that a significant amount of ground water is lost to evapotranspiration in the area.

During calibration, the recharge rate to till, where till is the uppermost unit, was varied uniformly from 0.0 to $1.0 \mathrm{in} / \mathrm{yr}$. The best correspondence between the observed and model-computed water levels for the model was for an areal-recharge rate to till at land surface of $0.22 \mathrm{in} / \mathrm{yr}$. This rate agrees favorably with the leakage rates to confined aquifers estimated from field data. 


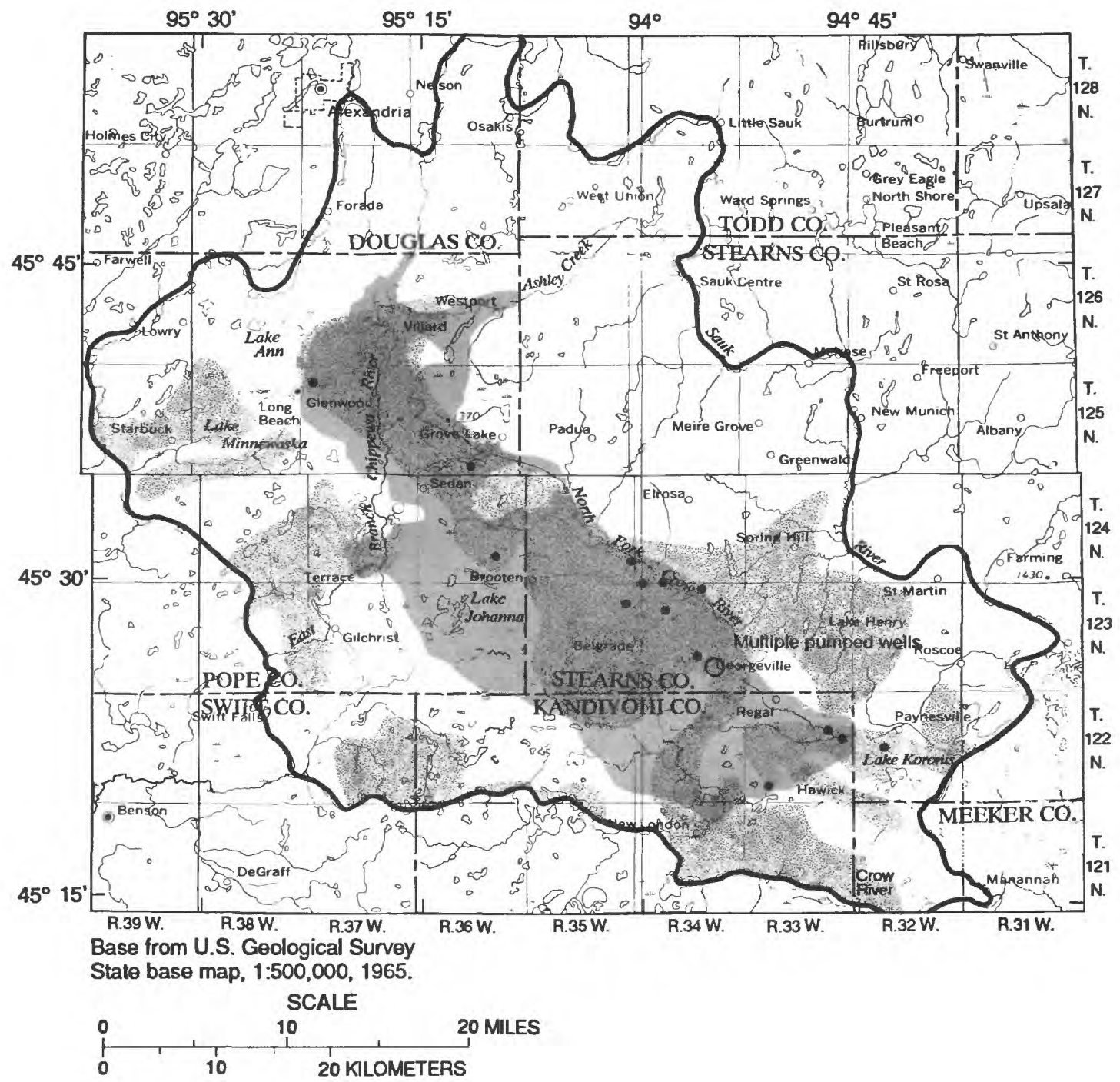

\section{EXPLANATION}

Area in which ground-water flow was simulated (aquifer)

Study area

Hydrological boundary

- $\quad$ Pumped well

Figure 19.--Location of pumped wells simulated in zone D, layer 5 


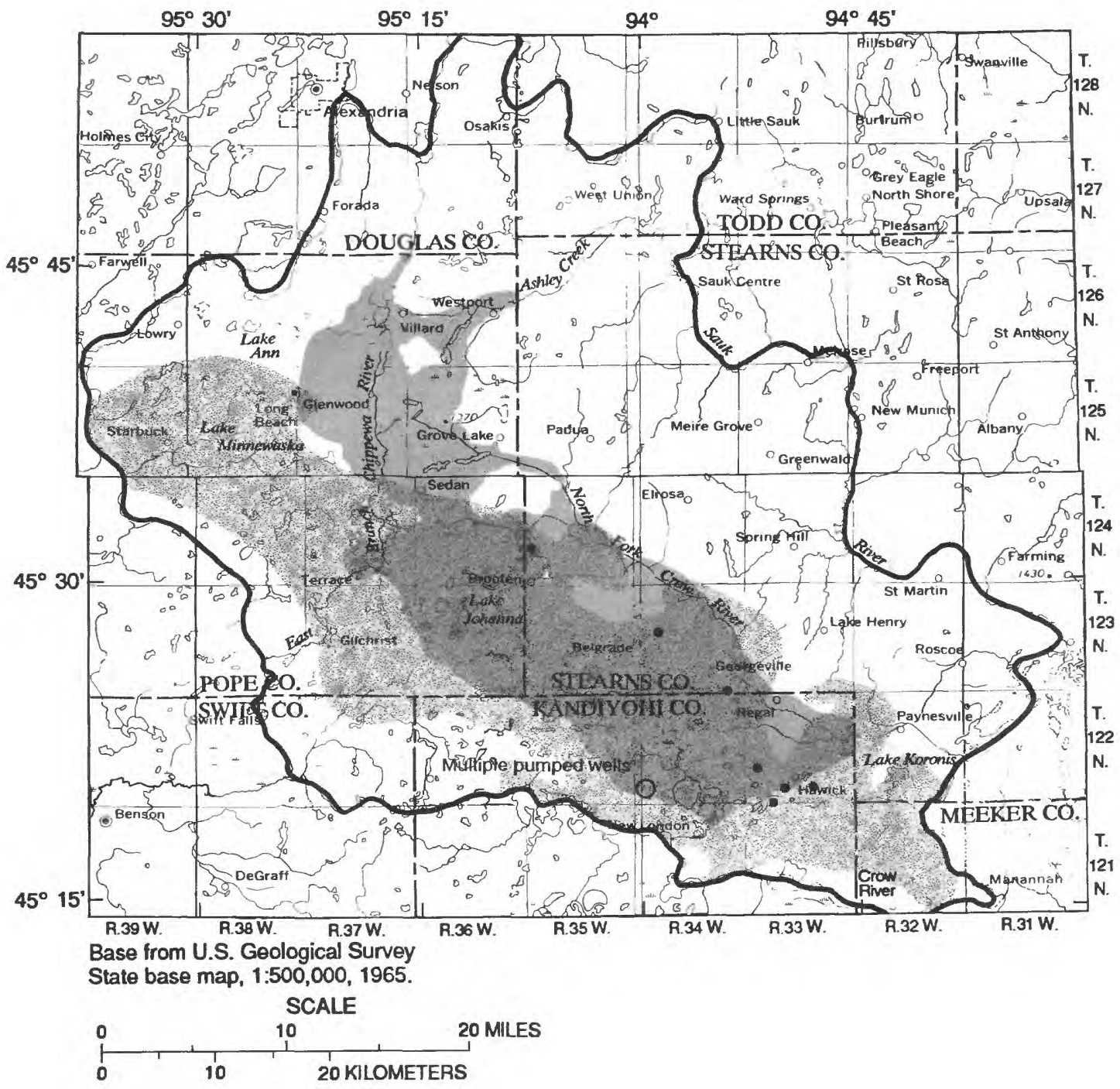

\section{EXPLANATION}

Area in which ground-water flow was simulated (aquifer)

Study area

Hydrological boundary

- $\quad$ Pumped well

Figure 20.-Location of pumped wells simulated in zone E, layer 6 


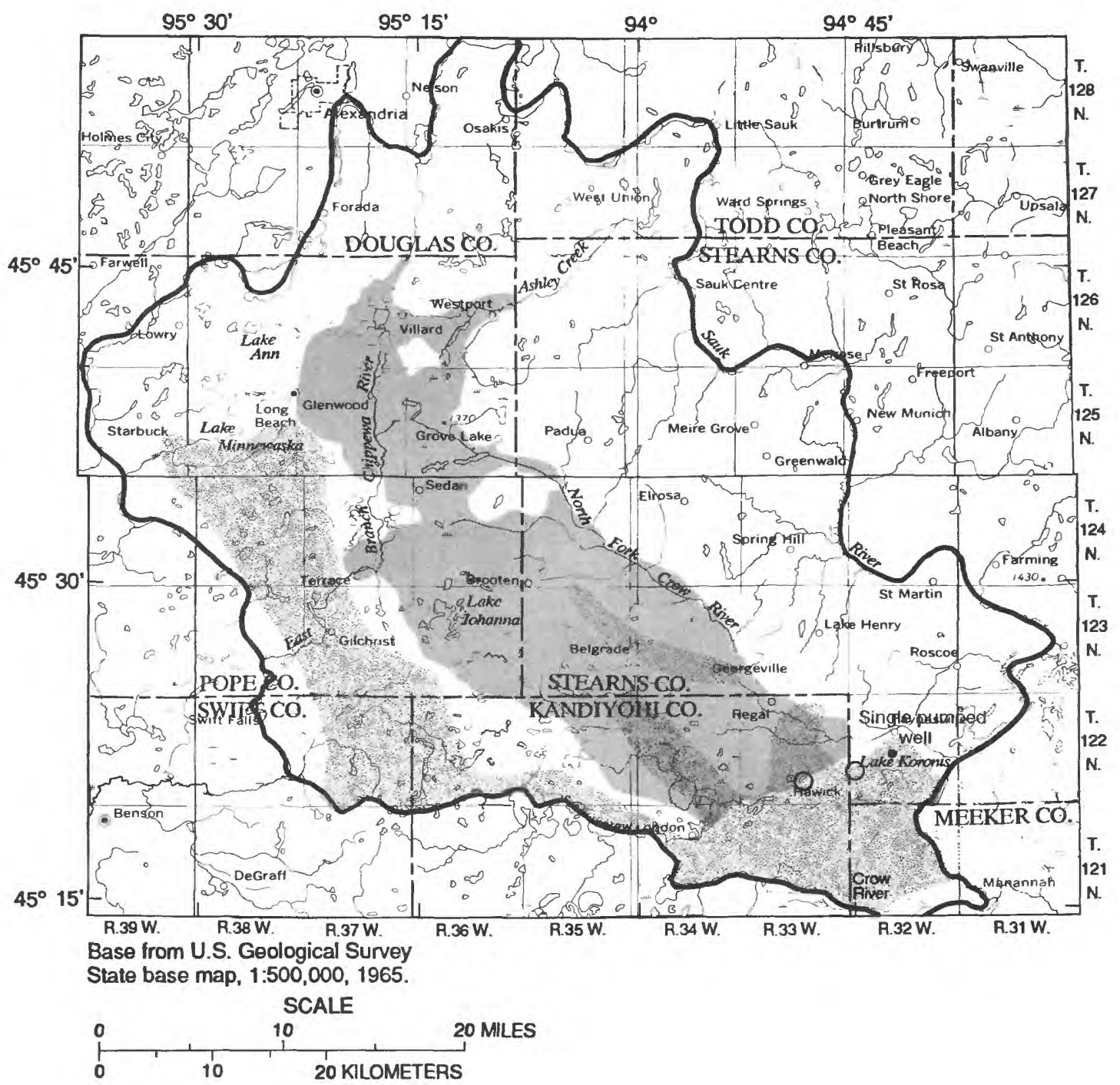

\section{EXPLANATION}

Area in which ground-water flow was simulated (aquifer)

Study area

Hydrological boundary

O More than one pumped well

Figure 21.-Location of pumped wells simulated in zone F, layer 7 
The model-computed steady-state potentiometric surface for each model layer plus the difference between representative model-computed and measured (1985) water levels are shown in figures 6-12. The general flow patterns shown in these figures agree favorably with potentiometric data provided by Delin (1988). A positive number at a well location indicates a model-computed water level higher than the measured value. The absolute value of the mean difference between the measured and model-computed heads for the seven layers ranged from about 1 to $10 \mathrm{ft}$, with standard deviations ranging from about 17 to $35 \mathrm{ft}$. The model-computed water levels are within $30 \mathrm{ft}$ of measured values at 70 percent of the 125 observation points. The largest residuals (greater than $100 \mathrm{ft}$ ) were in layer 7 where hydrogeologic data are lacking. The larger residuals probably result also from the large changes in landsurface elevation within a given cell. Location of a measuring point near the perimeter of a cell in which a large change in elevation occurs commonly results in a large difference between model-computed and measured water levels.

Comparison of estimated and model-computed leakage to rivers is another way of testing how well the model simulates the real system. Model-computed leakage to river cells representing various reaches of the East Branch Chippewa and North Fork Crow Rivers (fig. 14) was compared to leakage estimated from stream discharge measured August 26-28, 1985, and August 25-27, 1986. The U.S. Geological Survey does not maintain continuous stream-flow-gaging stations on either of these streams in the area. Therefore, records maintained at stations downstream from the study area were investigated to determine how stream discharge measured in August of 1985 and 1986 compared to the periods of record. Available data indicate that flow in 1985 and 1986 for both the East Branch Chippewa and North Fork Crow Rivers exceeded or equaled the flows that could only be expected to occur between 10 and 20 percent of the time in a year. From these data, it is apparent that discharge of the East Branch Chippewa and North Fork Crow Rivers was above normal, or excessive, when both seepage measurements were made. Consequently, this ground-water-flow model, which is simulating steady-state, or average, conditions generally should be expected to underestimate discharge to the rivers.

The streambed-leakage coefficient was varied uniformly from 0.001 to 0.1 (ft/d)/ft. Adjustment of leakage coefficients of one order of magnitude produced differences in mean model-computed water levels of as much as $2 \mathrm{ft}$ in al1 model layers. The final steady-state leakage coefficient was 0.01 (ft/d)/ft. Model-computed and calculated ground-water discharge to the East Branch Chippewa and North Fork Crow Rivers are shown in table 2. River reaches for which ground-water discharge rates were calculated are shown on figure 14. As expected, most model-computed rates are lower than discharge rates estimated from field measurements made in 1985 and 1986. All model-computed rates are either lower than the estimated values or are within the range of values estimated for 1985 and 1986. Because the flow duration of both rivers was excessive during each gaging period, these data were used to insure that model-calibrated flows were in the proper order of magnitude for calibration. The data are presented here to illustrate the regional nature of the model which reflects steadystate, rather than excessive, streamflow conditions. 
Table 2.--Model-computed and calculated ground-water discharge to the East Branch Chippewa and North Fork Crow Rivers

[Discharge values are in million gallons per year]

\begin{tabular}{|c|c|c|c|c|}
\hline \multirow{4}{*}{ River } & \multirow{4}{*}{$\begin{array}{l}\text { River } \\
\text { reach } \\
\text { number } 1\end{array}$} & \multicolumn{3}{|c|}{ Ground-water discharge to river } \\
\hline & & \multicolumn{2}{|c|}{ Estimated $^{2}$} & \multirow{3}{*}{$\begin{array}{l}\text { Mode1- } \\
\text { computed }\end{array}$} \\
\hline & & \multicolumn{2}{|c|}{ Date } & \\
\hline & & $8-28-85$ & $8-27-86$ & \\
\hline North Fork Crow & 1 & 1,861 & $-1,752$ & 219 \\
\hline Do. & 2 & 5,438 & $-3,248$ & 912 \\
\hline Do. & 3 & 620 & -182 & 219 \\
\hline Do. & 4 & 2,883 & 4,635 & 292 \\
\hline Do. & 5 & -766 & 15,439 & 401 \\
\hline Do. & 6 & -219 & 6,752 & 1,788 \\
\hline Do. & 7 & 401 & 1,679 & 693 \\
\hline \multirow[t]{2}{*}{ Do. } & 8 & 584 & 2,628 & 657 \\
\hline & Total discharge & 10,802 & 25,951 & 5,181 \\
\hline $\begin{array}{c}\text { East Branch } \\
\text { Chippewa }\end{array}$ & 9 & 36 & 3,905 & 182 \\
\hline Do. & 10 & 36 & $-1,314$ & 36 \\
\hline Do. & 11 & 292 & 1,533 & 1,314 \\
\hline \multirow[t]{2}{*}{ Do. } & 12 & 1,825 & 4,891 & 1,898 \\
\hline & Total discharge & 2,189 & 9,015 & 3,330 \\
\hline
\end{tabular}

1 See figure 14 for location of river reaches.

2 Negative number indicates flow from the river to the ground-water system. 
A ground-water budget is an accounting of inflow to, outflow from, and storage in the aquifer system. For steady-state conditions, inflow (sources) to the system equals outflow (discharges) from the system, with no change in storage. A general equation of the steady-state water budget in the modeled area can be written as:

\section{Recharge from precipitation (minus evapotranspiration) + ground-water flow into the modeled area = ground-water discharge to rivers + ground-water pumpage + ground-water discharge to springs and lakes.}

The steady-state water budget for the calibrated model (table 3 ) shows that recharge from precipitation accounts for the major inflow to the system. The table also shows that ground-water pumpage and discharge to the principal streams account for most of the discharge from the system. The model indicates that approximately 1.4 percent (or $256 \mathrm{Mgal} / \mathrm{yr}$ ) of the discharge is from springs surrounding Lake Minnewaska and along the Sauk River.

\section{Sensitivity Analysis}

A sensitivity analysis was conducted to determine the response of the model to changes in aquifer properties, recharge, and leakance. The sensitivity analysis consisted of uniformly increasing or decreasing selected model inputs and noting the change in simulated water levels. The model results were recorded as a change in the mean residual between the observed and the model-computed head as a function of the multiplication factor. The effect of changes in vertical hydraulic conductivity of till, hydraulic conductivity of the aquifers, and the areal-recharge rate on the model-computed head in layer 5 is shown in figure 22. Results of the analysis are shown for layer 5 as an example because wells in zone $D$ are some of the most intensively pumped in the area. Similar results were indicated for other layers of the model. The sensitivity of head to changes in streambed leakage coefficient was tested also, but results are not shown in figure 22 because the model-computed water levels and ground-water discharge proved to be insensitive to changes in this model input.

The vertical hydraulic conductivity of till, horizontal conductivity of the aquifers, and areal recharge were changed by as much as one order of magnitude above and below the calibrated values. Results indicate that the model is about equally insensitive to changes in the vertical hydraulic conductivity of till and the hydraulic conductivity of the aquifers when these inputs are uniformly changed throughout the model. Water levels were very sensitive to increases in the vertical hydraulic conductivity of till over a factor of about 5, and to decreases in the hydraulic conductivity of the aquifers below a factor of about 0.2. The model was sensitive to changes in the vertical hydraulic conductivity of till between any two layers alone, with greater than $5 \mathrm{ft}$ of water-level change in all layers following an order-ofmagnitude change. 
Table 3.--Steady-state water budget for the calibrated model

[Mgal/yr, million gallons per year]

Sources

$$
\begin{gathered}
\text { Rate } \\
(\mathrm{Mgal} / \mathrm{yr})
\end{gathered}
$$

Percent

$$
16,900
$$

Recharge from precipitation

$\begin{array}{r}800 \\ \hline 17,700\end{array}$

4

Chippewa and North Fork Crow Rivers

Total inflow

17,700

100

Rate
Mgal/yr)

11,100

63

Chippewa and North Fork Crow Rivers

Ground-water pumpage

6,000

34

Discharge directly to Lakes Minnewaska and Koronis

Springs surrounding Lake Minnewaska and along Sauk River
250

1

Total outflow

17,700

100 


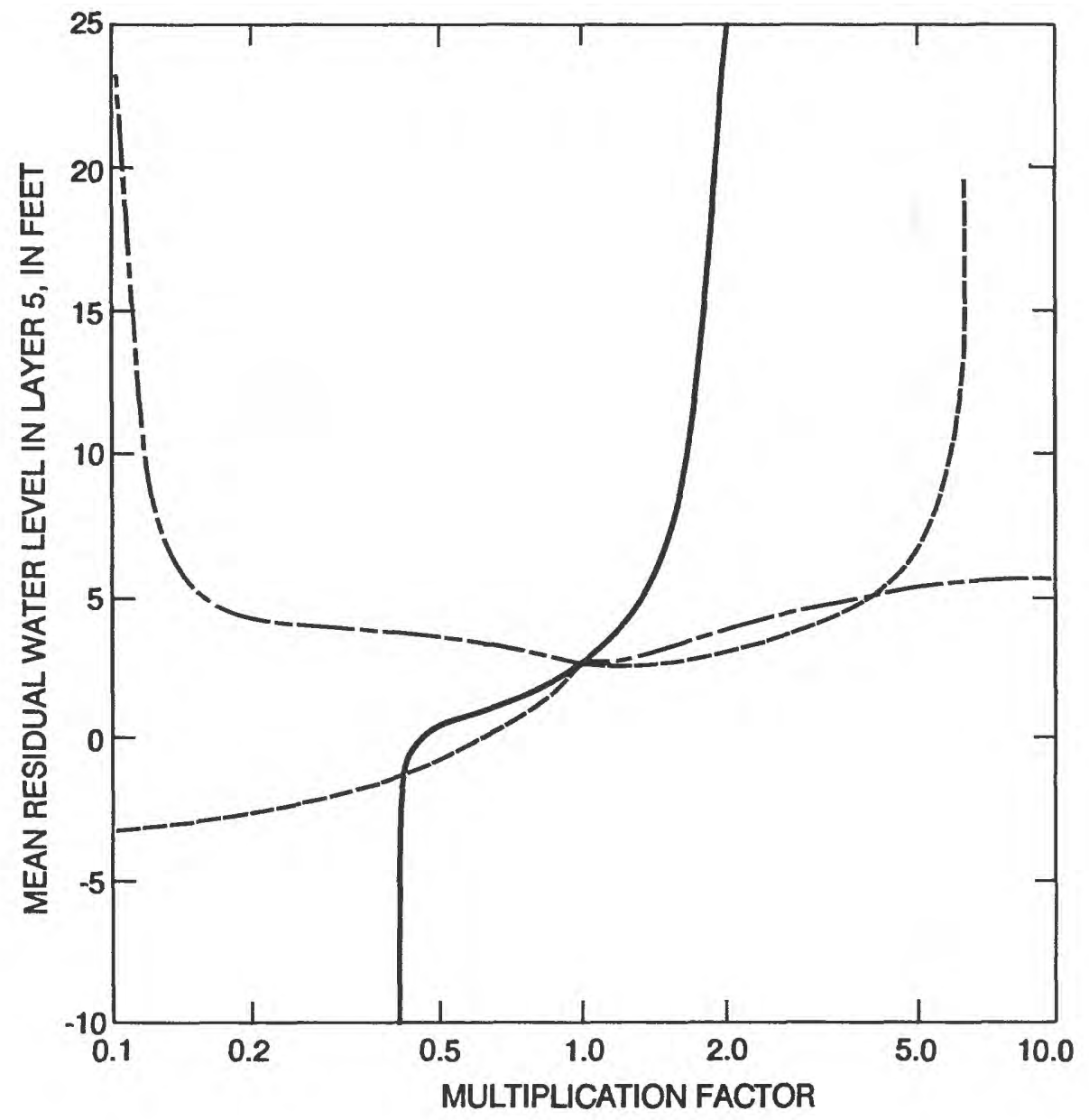

\section{EXPLANATION}

- Areal recharge rate

-_- Hydraulic conductivity of aquifer

-___ Vertical hydraulic conductivity of till

Figure 22.--Relations among parameters used in sensitivity analysis for the Brooten-Belgrade ground-flow model 
The model was most sensitive to changes in areal recharge (fig. 22). Waterlevel residuals were excessive using multiplication factors less than 0.4 and greater than 2.0. Many cells went dry when a multiplication factor less than 0.4 was used. A multiplication factor of 2.0 resulted in a mean residual of about 30 . The slope of the mean residual for this model input is the steepest of the three inputs shown in figure 22 .

Model sensitivity to the areal distribution of the aquifers was tested by simulating several discontinuities in aquifer zone $D$, layer 5 . This change in the model noticeably affected water levels in layers 3 through 7 . The mean residual in layer 5, for example, increased from 2.4 to $11.2 \mathrm{ft}$ as a result of simulation of the discontinuities. This is an indication that more hydrogeologic information is needed to improve the definition of the areal extent and thickness of the confined aquifers and to simulate flow in the system. It also is an indication that the model should only be used with caution in making predictions of the effects of ground-water development on the hydrologic system.

The sensitivity analysis indicates that areal recharge is the most important input in controlling flow in the ground-water system. This is not surprising and supports the existing conceptual model. The sensitivity analysis also indicates that more accurate information on recharge to the ground-water system and on areal extent and thickness of the confined aquifers would improve calibration of the model.

\section{Results of Simulations}

The calibrated steady-state model was used to evaluate ground-water availability by assessing the potential effects of hypothetical conditions on ground-water levels and streamflow in the area. The hypothetical simulations test (1) the effects of historical and 1984 pumping, (2) the effects of an extended drought, and (3) the potential for additional ground-water development from aquifer zones A through $\mathrm{E}$.

The hypothetical simulations described in this section were steady-state simulations. Thus, simulated results indicate the long-term effects of the hypothetical conditions simulated because, unlike transient simulations, no water is derived from storage. The 1985 heads were used as the initial condition for each steady-state simulation. Table 4 is a summary of the hypothetical model simulations and corresponding aquifer responses. Table 5 summarizes the water budget for each simulation.

The model simulated the amount of ground-water leakage between the confined aquifer zones and the surficial aquifer. The approximate simulated leakage from overlying deposits to the confined aquifers is shown in table 6 . Because leakage between model layers is affected by pumpage from the drift aquifers, pumpage values for each aquifer zone are included in table 6 . The reduced leakage to layers 6 and 7, compared to layers 2 through 5 , is caused by the greater thickness of till separating aquifer zones $\mathrm{E}$ and $\mathrm{F}$ from overlying zones, which results in a lower leakage rate. The lower volume of ground water pumped from zones $E$ and $F$, compared to aquifer zones $C$ and $D$, may also result in a reduced leakage rate. These results indicate that aquifer zones $\mathrm{E}$ and $\mathrm{F}$ could be much more susceptible to long-term water-level declines compared to the other aquifers. 
Table 4.--Summary of results of bypothetical nodel sinulations A, B, C1, C2, C3, C4, and C5

\begin{tabular}{|c|c|c|}
\hline Simulation & Conditions of simulation & Model results \\
\hline A & $\begin{array}{l}\text { Predevelopment: } 1984 \\
\text { pumping removed to } \\
\text { determine effects } \\
\text { of historical } \\
\text { pumpage } \\
\text { Recharge: } 1.8 \text { inches per year }\end{array}$ & $\begin{array}{l}\text { Water levels have declined from } 5 \\
\text { to } 10 \text { feet regionally in all zones. } \\
\text { Declines have been greatest near } \\
\text { Belgrade. Ground-water discharge } \\
\text { to rivers has decreased } 25 \text { percent } \\
\text { since predevelopment. }\end{array}$ \\
\hline $\mathbf{B}$ & $\begin{array}{l}\text { Present well development } \\
\quad(344 \text { wells) } \\
\text { Pumping stress: actual } \\
\quad(1984) \times 1.5 \\
\text { Drought: 25-percent } \\
\text { less recharge for } \\
\text { 3-year duration }\end{array}$ & $\begin{array}{l}\text { Water levels decline from } 2 \text { to } 5 \\
\text { feet regionally in each zone and as } \\
\text { much as } 20 \text { feet locally. Ground- } \\
\text { water discharge to rivers is reduced } \\
\text { by } 47 \text { percent of } 1984 \text { conditions. }\end{array}$ \\
\hline $\mathrm{Cl}$ & $\begin{array}{l}\text { Present + hypothetical } \\
\text { well development: } \\
10 \text { in aquifer zone A } \\
\text { ( } 354 \text { wells total) } \\
\text { Pumping stress: } \\
\text { actual + estimated } \\
\text { Recharge: } 1.8 \text { inches per year }\end{array}$ & $\begin{array}{l}\text { Water levels decline from } 0.2 \text { to } \\
0.4 \text { feet regionally and as much as } \\
1.4 \text { feet locally in aquifer zone } \mathrm{A} \text {. } \\
\text { Water levels decline as much as } 1.4 \\
\text { feet in overlying surficial aquifer } \\
\text { and as much as } 0.8 \text { feet in underlying } \\
\text { aquifer zone B. }\end{array}$ \\
\hline $\mathrm{C} 2$ & $\begin{array}{l}\text { Present + hypothetical } \\
\text { well development: } \\
15 \text { in aquifer zone B } \\
\text { ( } 359 \text { wells total) } \\
\text { Pumping stress: } \\
\text { actual + estimated } \\
\text { Recharge: } 1.8 \text { inches per year }\end{array}$ & $\begin{array}{l}\text { Water levels decline from } 0.1 \text { to } \\
0.5 \text { feet regionally and as much as } \\
2.7 \text { feet locally in aquifer zone B. } \\
\text { Water levels decline as much as } 0.7 \\
\text { feet in overlying aquifer } 2 \text { one } A \\
\text { and as much as } 0.9 \text { feet in underlying } \\
\text { aquifer zone C. }\end{array}$ \\
\hline C3 & $\begin{array}{l}\text { Present + hypothetical } \\
\text { well development: } \\
20 \text { in aquifer zone } C \\
\text { ( } 364 \text { wells total) } \\
\text { Pumping stress: } \\
\text { actual + estimated } \\
\text { Recharge: } 1.8 \text { inches per year }\end{array}$ & $\begin{array}{l}\text { Water levels decline from } 0.1 \text { to } \\
1.0 \text { feet regionally and as much as } \\
2.0 \text { feet locally in aquifer zone C. } \\
\text { Water levels decline as much as } 0.9 \\
\text { feet in overlying aquifer zone B and } \\
\text { as much as } 0.4 \text { feet in underlying } \\
\text { aquifer zone } D \text {. }\end{array}$ \\
\hline $\mathrm{C}_{4}$ & $\begin{array}{l}\text { Present + hypothetical } \\
\text { well development: } \\
20 \text { in aquifer zone } D \\
\text { ( } 364 \text { wells total) } \\
\text { Pumping stress: } \\
\text { actual + estimated } \\
\text { Recharge: } 1.8 \text { inches per year }\end{array}$ & $\begin{array}{l}\text { Water levels decline from } 0.1 \text { to } \\
0.5 \text { feet regionally and as much as } \\
1.2 \text { feet locally in aquifer zone } D \text {. } \\
\text { Water levels decline as much as } 0.5 \text { feet } \\
\text { in overlying aquifer zone } C \text { and as much } \\
\text { as } 0.7 \text { feet in underlying aquifer zone } E \text {. }\end{array}$ \\
\hline $\mathrm{C5}$ & $\begin{array}{l}\text { Present + hypothetical } \\
\text { well development: } \\
20 \text { in aquifer zone } \mathrm{E} \\
\text { ( } 364 \text { wells total) } \\
\text { Pumping stress: } \\
\text { actual + estimated } \\
\text { Recharge: } 1.8 \text { inches per year }\end{array}$ & $\begin{array}{l}\text { Water levels decline from } 0.5 \text { to } \\
1.0 \text { feet regionally and as much as } \\
5.0 \text { feet locally in aquifer } E \text {. } \\
\text { Water levels decline as much as } 2.8 \text { feet } \\
\text { in overlying aquifer zone } E \text { and as much } \\
\text { as } 0.4 \text { feet in underlying aquifer zone } F \text {. }\end{array}$ \\
\hline
\end{tabular}

* Pumping rate for each hypothetical well is 12.3 million gallons per year 


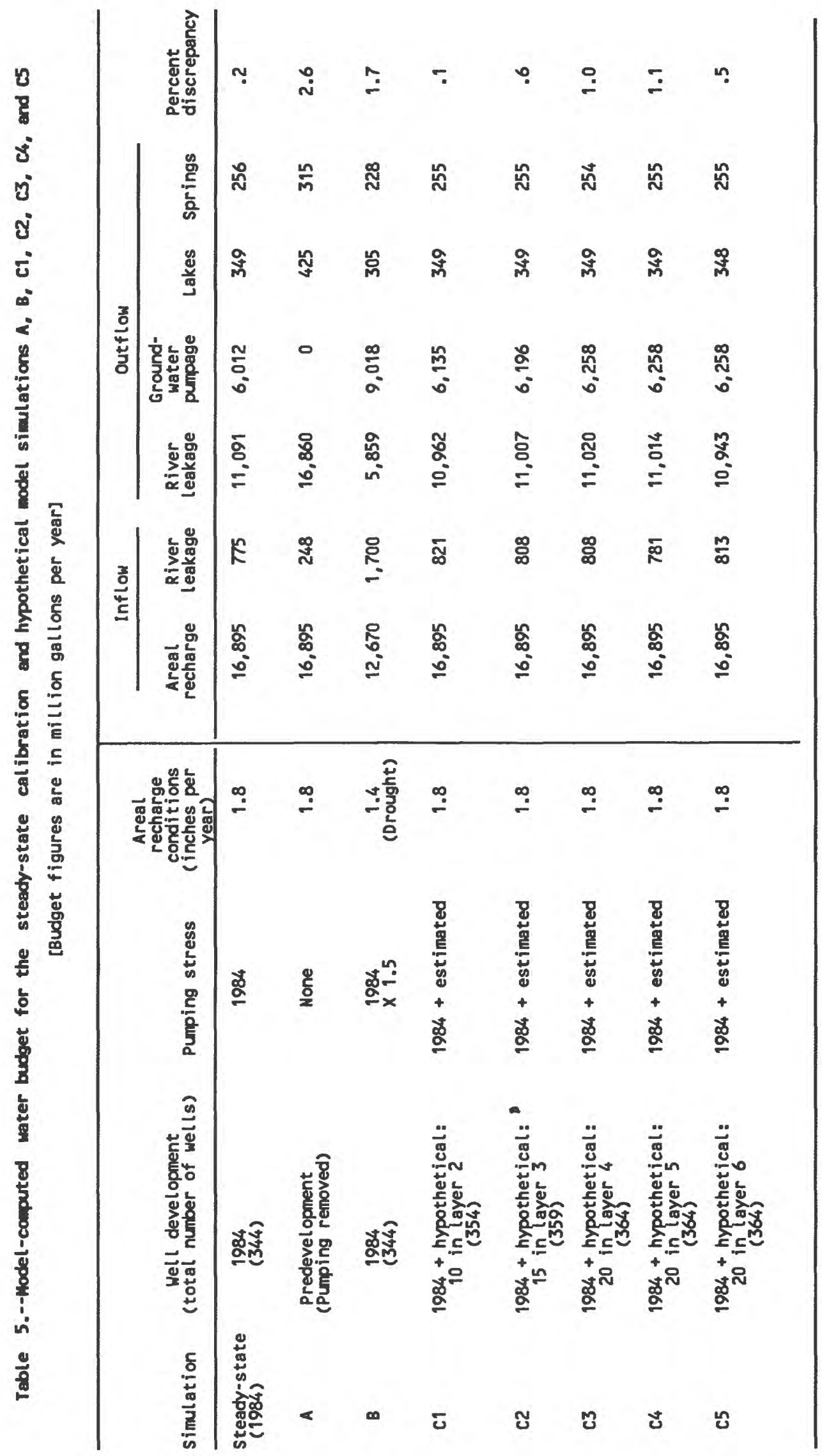


Table 6.-- Pumpage and model-computed leakage between aquifers

[Pumpage and leakage values in millions of gallons per year]

\begin{tabular}{cccc}
$\begin{array}{c}\text { Aquifer } \\
\text { zone }\end{array}$ & $\begin{array}{c}\text { Layer } \\
\text { number }\end{array}$ & Pumpage & $\begin{array}{c}\text { Leakage between } \\
\text { aquifers }\end{array}$ \\
\hline Surficial & 1 & $4,103.0$ & 2,200 \\
A & 2 & 126.4 & 2,700 \\
B & 3 & 93.8 & 2,800 \\
C & 4 & 846.8 & 2,500 \\
D & 5 & 851.5 & 70 \\
E & 6 & 215.3 & 40 \\
F & 7 & 17.1 & \\
\hline
\end{tabular}

Model results indicate that, for steady-state conditions, heads in the drift aquifers decrease with depth, except near rivers, and are generally within $3 \mathrm{ft}$ of each other. However, field data indicate that head differences between the aquifers, on a seasonal basis, are greater than what the model indicates because of seasonal pumpage effects.

\section{Predevelopment Conditions}

Simulation A (table 5) was designed to evaluate the effects on the groundwater system of historical and 1984 pumping. This was achieved by removing pumping from the steady-state model and simulating average recharge conditions. Mode1 results, therefore, are an estimate of predevelopment equilibrium conditions. By comparing results of simulation A with the steady-state (1984) calibration, effects of historical pumping can be estimated. A majority of ground-water pumpage in the area is from irrigation wells that were installed after about 1970. Prior to this time the only significant ground-water pumpage was from a relatively few municipal, industrial, and commercial wells. Consequently, simulation $A$ is designed to estimate water-level and streamflow changes that have occurred in the aquifer system since about 1970 .

Mode1 results indicate that pumping has lowered water levels between 5 and $10 \mathrm{ft}$ regionally in all layers. Figures 23 and 24 illustrate model-computed water-level declines in the surficial aquifer and confined aquifers in zone $C$ for simulation $A$. Water-level declines in the remaining aquifer zones are similar to those shown for zone $C$ in figure 15. Water-1evel declines have been greatest near Belgrade. Declines greater than $15 \mathrm{ft}$ have occurred in the surficial aquifer southwest of Belgrade (fig. 23), in zone C northeast of Belgrade (fig. 24), and in zone D southeast of Belgrade. Ground-water discharge to the East Branch Chippewa and North Fork Crow Rivers has been reduced by 38 percent compared to predevelopment conditions. 


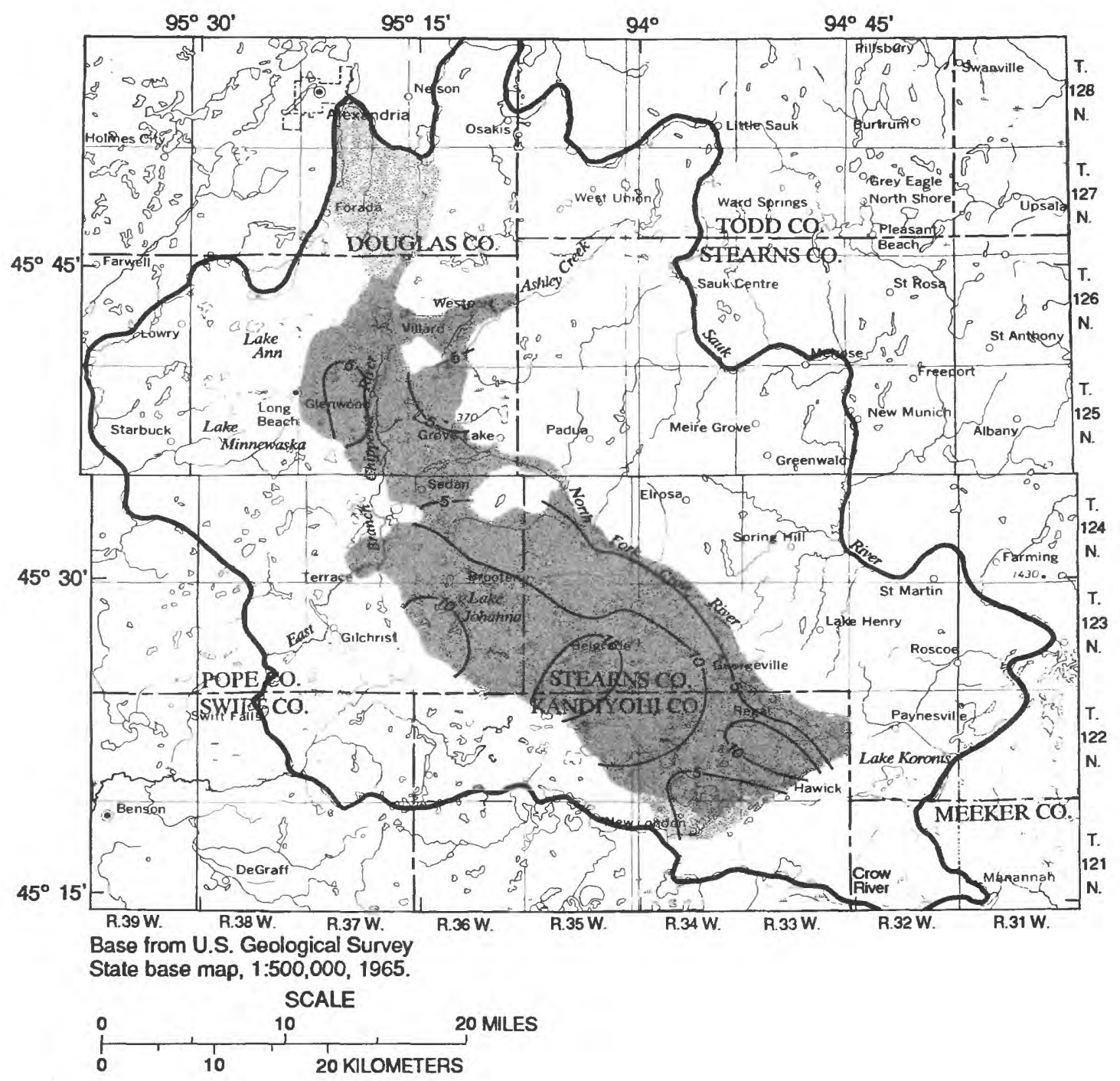

\section{EXPLANATION}

Area in which ground-water flow was simulated (aquifer)

Study area
Hydrological boundary
$-5-\quad \begin{gathered}\text { Water-level-decline contour. Shows model- } \\ \text { computed water-level declines. Interval } 5 \text { feet. }\end{gathered}$

Figure 23.--Model-computed water-level declines in the surficial aquifer (layer 1 ) that have resulted from pumping under steady-state conditions from predevelopment to 1984 (simulation A) 


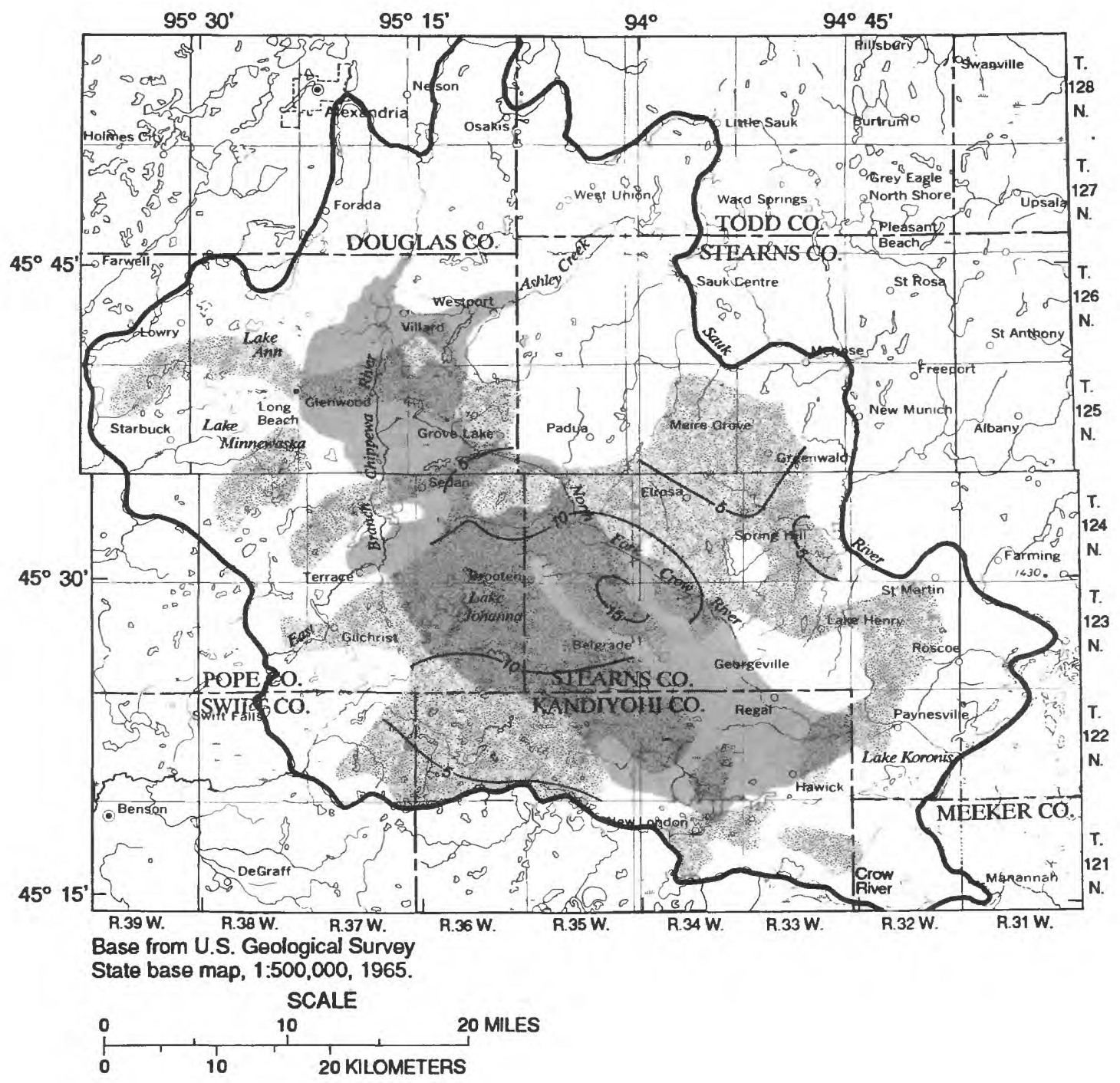

\section{EXPLANATION}

Area in which ground-water flow was simulated (aquifer)

Study area

Hydrological boundary

-5- Water-level-decline contour. Shows modelcomputed water-level declines. Interval 5 feet.

Figure 24.--Model-computed water-level declines in zone $C$ (layer 4 ) that have resulted from pumping under steady-state conditions from predevelopment to 1984 (simulation A) 
Simulation B was designed to investigate the effects of a drought similar in severity to the drought of 1976-77. The experiment was a steady-state simulation in which areal recharge was reduced by 25 percent throughout the model. Because pumping for irrigation increases during a drought, pumpage rates were increased by 50 percent for all existing wells. A separate transient simulation was run to determine the approximate length of time the simulated drought represents. Storage coefficients of 0.2 and $2.0 \times 10^{-2}$ were used in the transient simulation for the unconfined and confined aquifers, respectively. Transient storage effects for the confining layers were not simulated. The transient simulation indicated that it would take the ground-water system about 3 years to reach steady-state under the simulated conditions. Thus, the steady-state simulation represents a drought of approximately 3 years' duration. All model-computed water-level declines mentioned in this and following sections are in addition to the historical declines that occurred prior to 1984.

Mode1 results indicate that water levels may decline 2 to $10 \mathrm{ft}$ regionally in each confined aquifer zone and as much as $20 \mathrm{ft}$ locally in the surficial aquifer as a result of the simulated drought (figs. 25 - 31). Several waterbudget terms summarized in table 5 are significantly affected by the simulated drought, compared to 1984 conditions. Increased pumping during the hypothetical drought resulted in a 206-percent increase in leakage from the East Branch Chippewa and North Fork Crow Rivers to the aquifer system. In addition, discharge to the East Branch Chippewa and North Fork Crow Rivers would be reduced by 47 percent of 1984 conditions. Discharge from confined aquifers to Lakes Minnewaska and Koronis would be reduced by about 11 percent and discharge to springs around Lake Minnewaska and along the Sauk River would be reduced by about 9 percent.

\section{Increased Development}

The simulations described in this section were designed to estimate the steady-state effects of a hypothetical increase in the number of pumping centers in several of the confined aquifers. Expanded development was simulated in aquifer zones $A$ through $E$ because they are the most areally extensive aquifer zones. Expanded development was not simulated in aquifer zone F, which occurs primarily outside the study area. Hypothetical wells were located in areas of sandy soils where future ground-water development is likely. The wells were spaced throughout each aquifer zone to minimize well-interference problems with existing and added hypothetical wells. The number of wells simulated in each zone (10, 15 or 20) was determined based on these criteria. The average pumping rate for irrigation wells in the modeled area, $12.3 \mathrm{Mgal} / \mathrm{yr}$, was specified as the pumping rate for each hypothetical well. It must be emphasized that the hypothetical simulations were allowed to reach equilibrium conditions, whereas the ground-water system probably would not reach equilibrium during a given pumping season. Therefore, actual drawdowns in an overlying or underlying (unpumped) aquifer zone would be less than the simulated values. In addition, head differences between the various aquifer zones during a given pumping season probably would be greater than the simulated differences. 


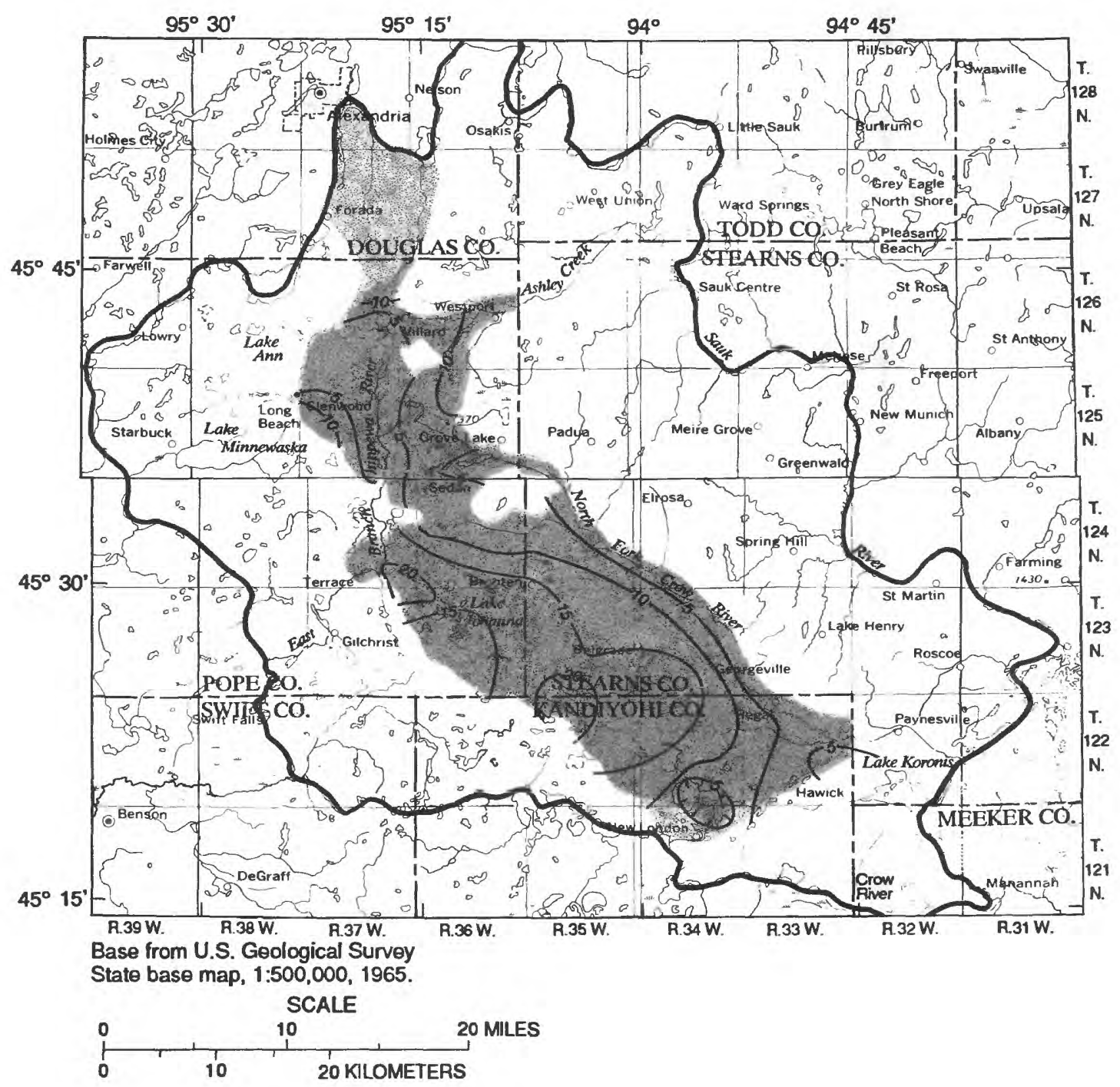

\section{EXPLANATION}
Area in which ground-water flow was simulated (aquifer)
Study area
Hydrological boundary
-5- Water-level-decline contour. Shows model- computed water-level declines. Hachures indicate depression. Interval 5 feet.




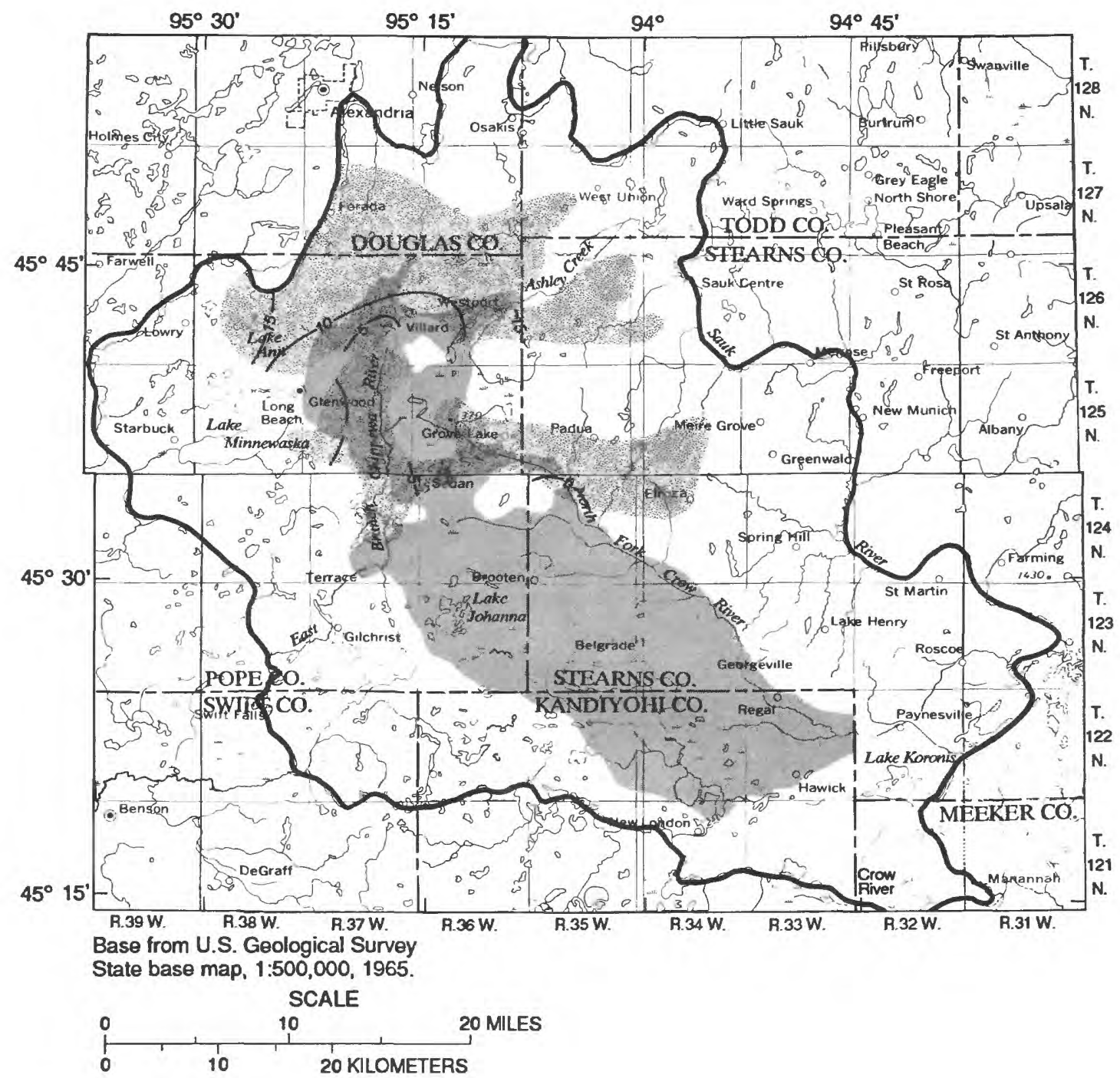

\section{EXPLANATION}

Area in which ground-water flow was simulated (aquifer)

Study area

Hydrological boundary

-5 - Water-level-decline contour. Shows model-

computed water-level declines. Interval 5 feet.

Figure 26.--Model-computed water-level declines in zone A (layer 2) following an extended drought (simulation $B$ ) 


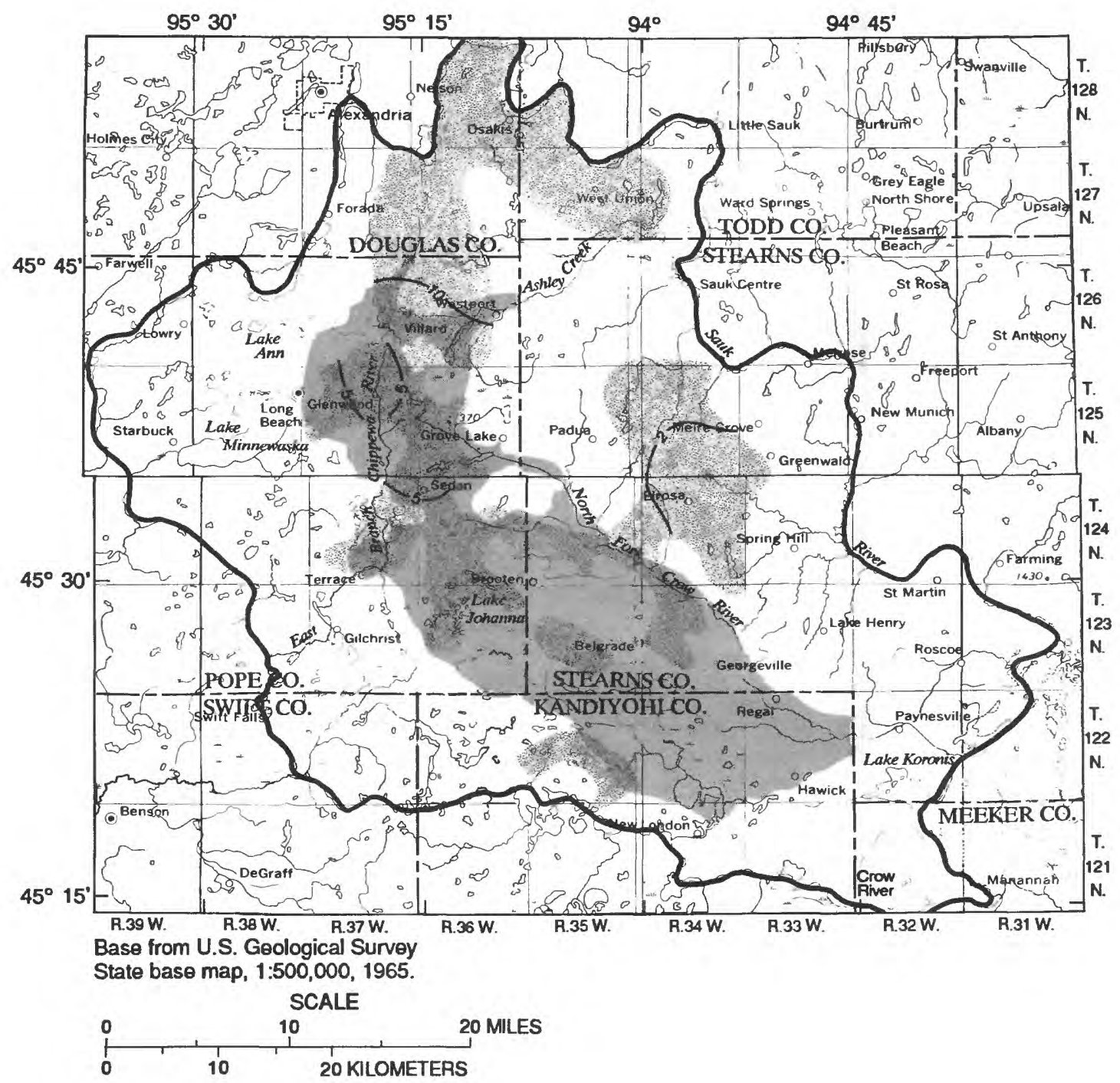

\section{EXPLANATION}

Area in which ground-water flow was simulated (aquifer)

Study area

Hydrological boundary

-5- Water-level-decline contour. Shows modelcomputed water-level declines. Interval 3 and 5 feet. 
Simulation $\mathrm{Cl}$ was designed to estimate the effects of a hypothetical increase in the number of pumping centers withdrawing from aquifer zone A. Withdrawals from 10 hypothetical we1ls, pumping a total of $123 \mathrm{Mgal} / \mathrm{yr}$, were simulated (fig. 32). Simulation $\mathrm{Cl}$ results indicate that water levels may decline between 0.2 and $0.4 \mathrm{ft}$ regionally in zone $A$ and as much as $1.4 \mathrm{ft}$ southeast of Glenwood as a result of the hypothetical withdrawals (fig. 32). Water-level declines as great as $1.4 \mathrm{ft}$ in the overlying surficial aquifer and $0.8 \mathrm{ft}$ in the underlying zone $\mathrm{B}$ aquifers also may occur in response to hypothetical withdrawals from zone A. Pumping of the hypothetical wells would reduce ground-water discharge to the East Branch Chippewa River by about 1 percent.

Simulation C2 was designed to estimate the effects of a hypothetical increase in the number of pumping centers withdrawing from aquifer zone B. Withdrawals from 15 hypothetical wells, pumping a total of $184.5 \mathrm{Mgal} / \mathrm{yr}$, were simulated (fig. 33). Simulation $C 2$ results indicate that waterlevels may decline from 0.1 to $0.5 \mathrm{ft}$ regionally and as much as $2.7 \mathrm{ft}$ southeast of Sedan in zone B due to the hypothetical withdrawals (fig. 33). Water-level declines as great as $0.7 \mathrm{ft}$ in the overlying zone $A$ aquifers and $0.9 \mathrm{ft}$ in the underlying zone $C$ aquifers also may occur in response to hypothetical withdrawals from zone B. Pumping of the hypothetical wells would reduce ground-water discharge to the East Branch Chippewa and North Fork Crow Rivers by about 1 percent.

Simulation C3 was designed to estimate the effects of a hypothetical increase in the number of pumping centers withdrawing from aquifer zone $C$. Withdrawals from 20 wells, pumping a total of $246 \mathrm{Mgal} / \mathrm{yr}$, were simulated (fig. 34). Simulation C3 results indicate that water levels may decline between 0.1 and $1 \mathrm{ft}$ regionally and as much as $2 \mathrm{ft}$ southwest of Belgrade in zone $C$ as a result of the hypothetical withdrawals (fig. 34). Water-level declines as great as $0.9 \mathrm{ft}$ in the overlying zone B aquifers and $0.4 \mathrm{ft}$ in the underlying zone $D$ aquifers also may occur in response to hypothetical withdrawals from zone $C$. Pumping of the hypothetical wells would reduce ground-water discharge to the East Branch Chippewa and North Fork Crow Rivers by about 1 percent.

Simulation $\mathrm{C} 4$ was designed to estimate the effects of a hypothetical increase in the number of pumping centers withdrawing from aquifer zone D. Withdrawals from 20 hypothetical wells, pumping a total of $246 \mathrm{Mgal} / \mathrm{yr}$, were simulated (fig. 35). Simulation C4 results indicate that water levels may decline between 0.1 and $0.5 \mathrm{ft}$ regionally and as much as $1.2 \mathrm{ft}$ southeast of Sedan in zone D as a result of the hypothetical withdrawals (fig. 35). Waterlevel declines as great as $0.5 \mathrm{ft}$ in the overlying zone $\mathrm{C}$ aquifers and $0.7 \mathrm{ft}$ in the underlying zone $\mathrm{E}$ aquifers also may occur in response to hypothetical withdrawals from zone D. Pumping of the hypothetical wells would reduce ground-water discharge to the East Branch Chippewa and North Fork Crow Rivers by about 1 percent. 


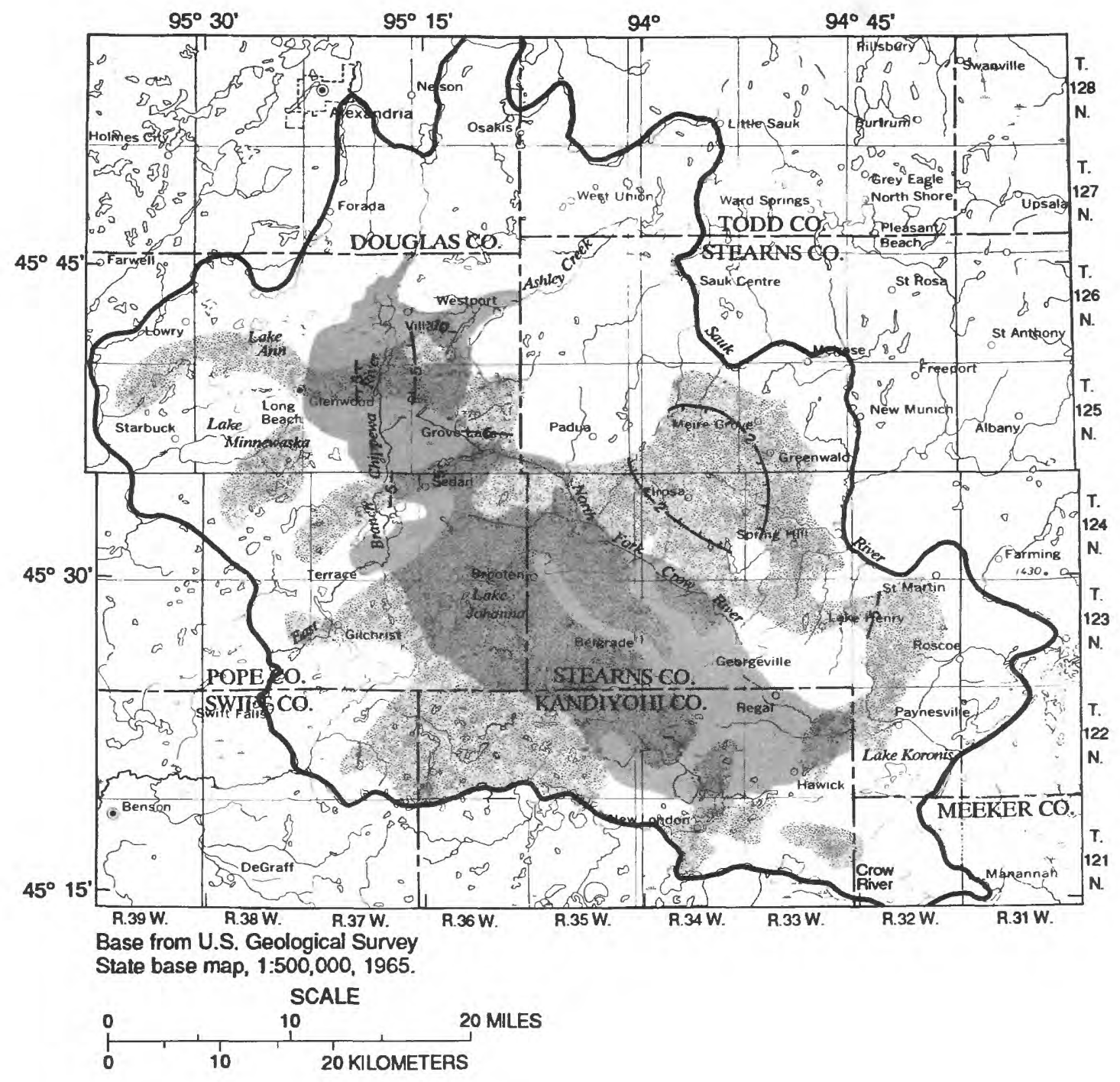

\section{EXPLANATION}

Area in which ground-water flow was simulated (aquifer)

Study area

Hydrological boundary

-5- Water-level-decline contour. Shows modelcomputed water-level declines. Hachures indicate depression. Interval 3 and 5 feet.

Figure 28.--Model-computed water-level declines in zone $\mathrm{C}$ (layer 4) following an extended drought (simulation B) 


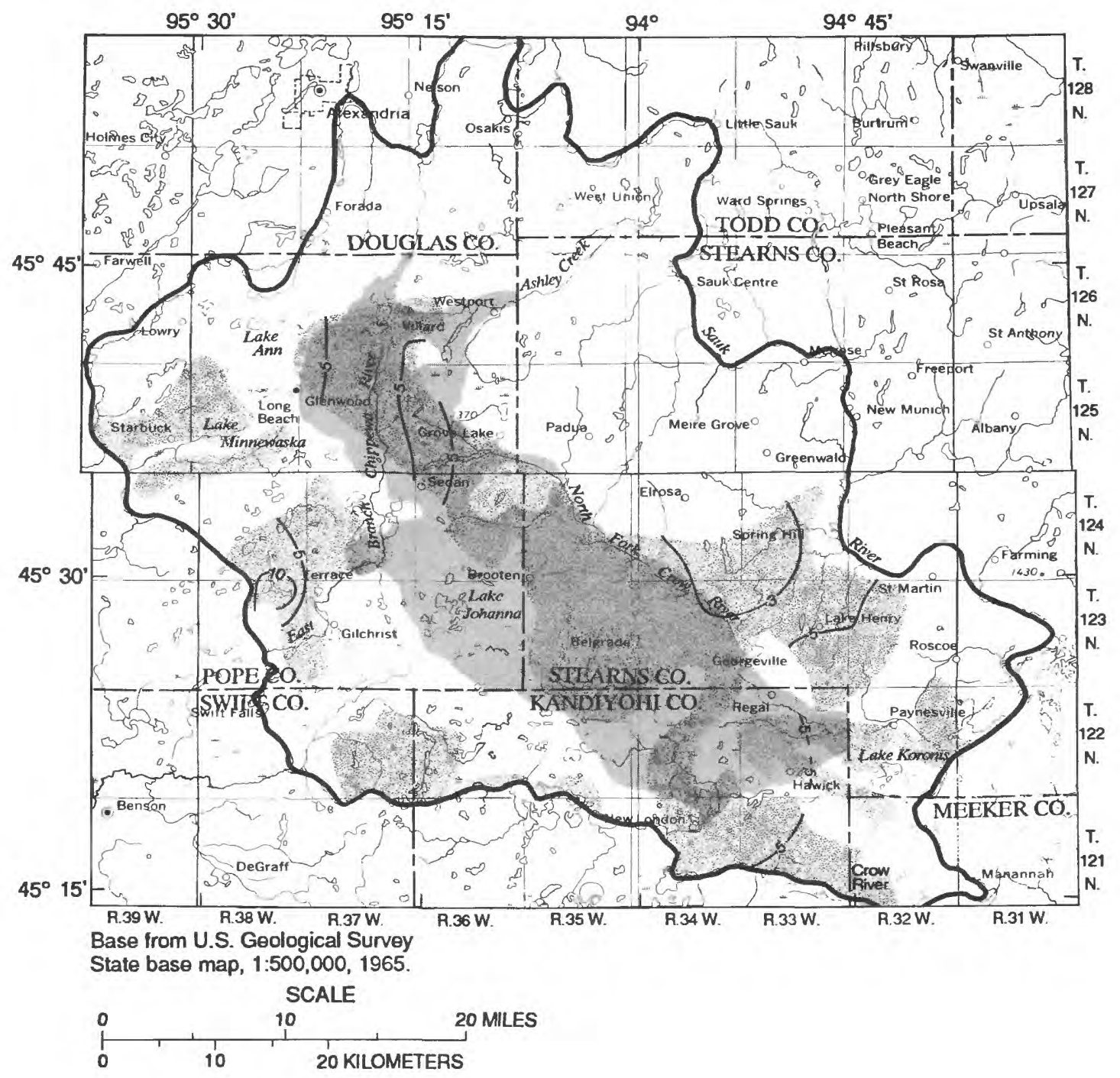

\section{EXPLANATION}

Area in which ground-water flow was simulated (aquifer)

Study area

Hydrological boundary

- 5- Water-level-decline contour. Shows model-

computed water-level declines. Interval 2 and 5 feet.

Figure 29.--Model-computed water-level declines in zone D (layer 5) following an extended drought (simulation B) 


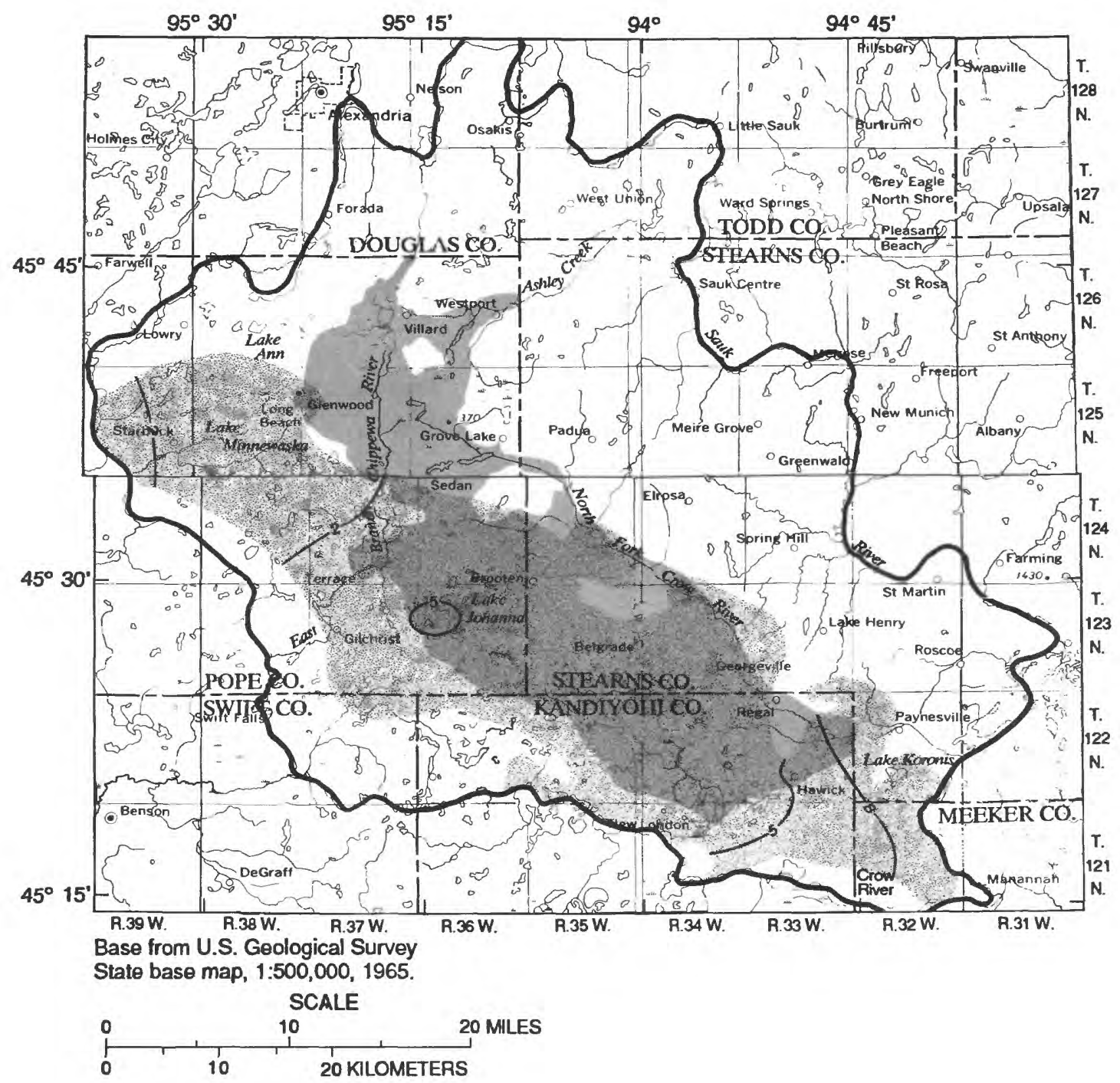

\section{EXPLANATION}

Area in which ground-water flow was simulated (aquifer)

Study area

Hydrological boundary

-5 W Water-level-decline contour. Shows modelcomputed water-level declines. Interval 3 feet.

Figure 30.--Model-computed water-level declines in zone $\mathrm{E}$ (layer 6 ) following an extended drought (simulation B) 


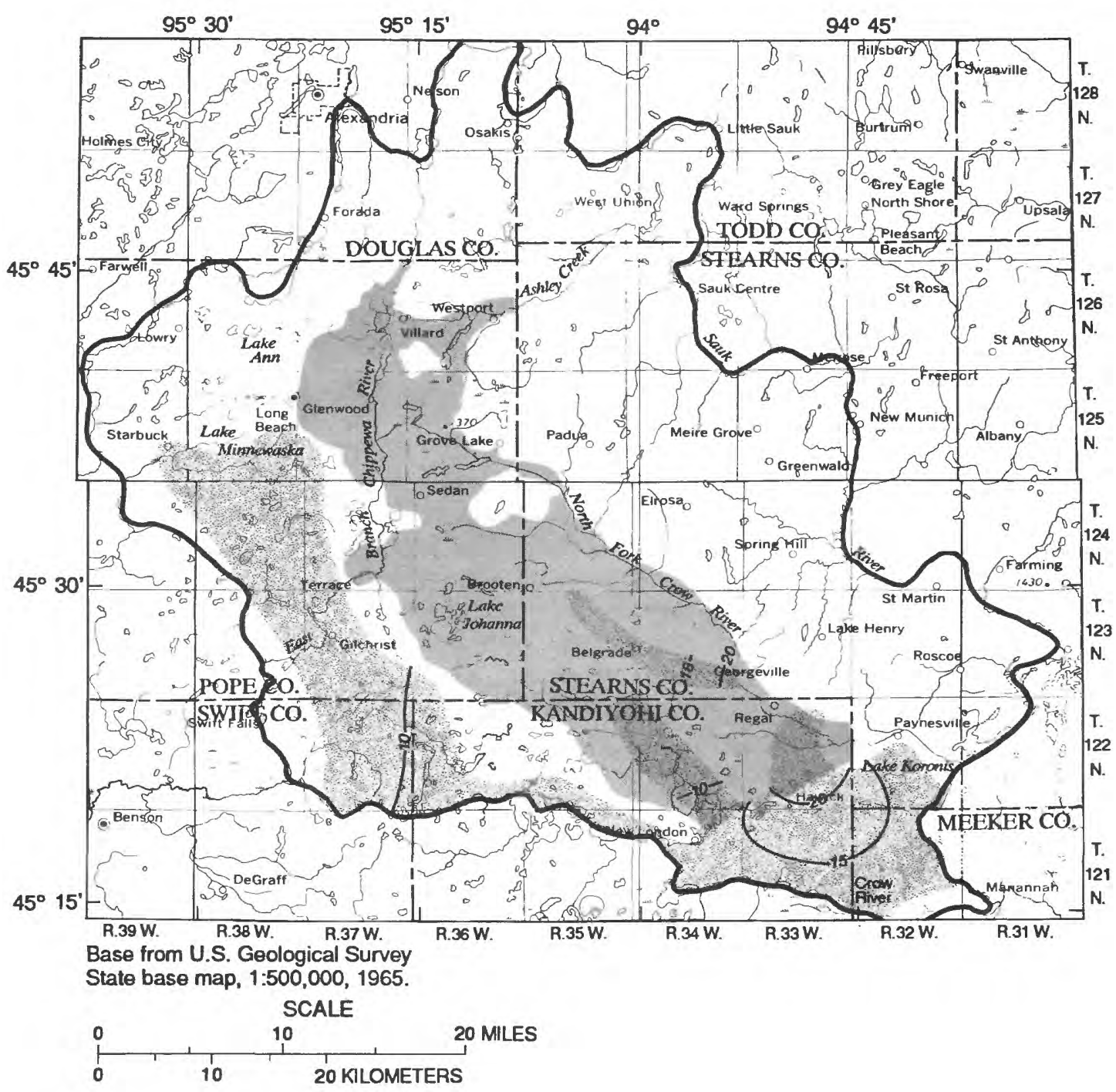

\section{EXPLANATION}

Area in which ground-water flow was simulated (aquifer)

Study area

Hydrological boundary

-10- Water-level-decline contour. Shows modelcomputed water-level declines. Interval 2 and 5 feet.

Figure 31.--Model-computed water-level declines in zone F (layer 7) following an extended drought (simulation B) 
Simulation C5 was designed to estimate the effects of a hypothetical increase in the number of pumping centers withdrawing from aquifer zone E. Withdrawals from 20 hypothetical we1ls, pumping a total of $246 \mathrm{Mgal} / \mathrm{yr}$, were simulated (fig. 36). Simulation C5 results indicate that water levels may decline between 0.5 and $1 \mathrm{ft}$ regionally and as much as $5 \mathrm{ft}$ west of Brooten in zone $\mathrm{E}$ as a result of the hypothetical withdrawals (fig. 36). Water-level declines as great as $2.8 \mathrm{ft}$ in the overlying zone $\mathrm{D}$ aquifers and $0.4 \mathrm{ft}$ in the underlying zone $\mathrm{F}$ aquifers also may occur in response to hypothetical withdrawals from zone E. Pumping of the hypothetical wells would reduce ground-water discharge to the East Branch Chippewa and North Fork Crow Rivers by about 1 percent.

Simulations $\mathrm{C1}$ through $\mathrm{C5}$ indicate that the confined aquifers in the Brooten-Belgrade area are capable of supporting additional pumping without seriously lowering ground-water and stream levels in the area. Based on the results of simulations $\mathrm{C1}$ through $\mathrm{C5}$, expanded development of water supplies from aquifer zone D probably would result in the least drawdown of potentiometric surfaces in the aquifer system. Because aquifer zone $D$ is present throughout much of the Brooten-Belgrade area, increased withdrawals from the zone are possible. In many locations southeast of Belgrade, zone $D$ is the uppermost aquifer zone present, allowing for the drilling of relatively inexpensive wells compared to costs of drilling into the deeper aquifers. Model results also indicate that expanded development of water supplies from aquifer zone E would result in the greatest drawdowns on water levels in the aquifer system. In most locations, however, overlying aquifers are present as alternate watersupply sources. Simulations C1 through C5 indicate that expanded development of water supplies probably would have minimal effects on ground-water discharge to the East Branch Chippewa and North Fork Crow Rivers.

The probable effects of simultaneous development of more than one of the aquifer zones can be estimated by the principle of superposition. This principle states that the solutions to individual parts of a problem can be added to solve a larger problem composed of the individual parts. A detailed description of the principle of superposition and its applications in ground-water hydraulics is presented by Reilly and others (1984).

The principle of superposition was first used to estimate the probable effects of simultaneous development of confined aquifers in zones $A$ through $E$ using the results of simulations $\mathrm{Cl}$ through C5. Therefore, 85 hypothetical wells, each pumping $12.3 \mathrm{Mgal} / \mathrm{yr}$, were simulated and distributed as described for simulations C1 through C5. Maximum water-leve1 declines for each aquifer zone in simulations $\mathrm{C1}$ through $\mathrm{C5}$ were added. The following results indicate the probable maximum water-1evel decline for each aquifer zone resulting from the superposition of simulations C1 through C5: surficial, $2.5 \mathrm{ft}$; zone A, $3.8 \mathrm{ft}$; zone B, $5.6 \mathrm{ft}$; zone C, $5.6 \mathrm{ft}$; zone D, $4.4 \mathrm{ft}$; zone E, $6.9 \mathrm{ft}$; and zone $\mathrm{F}, 1.1 \mathrm{ft}$.

The probable effects on water levels of a drought plus hypothetical development of wells in confined-aquifer zones $\mathrm{A}$ through $\mathrm{E}$ also were determined by superposition as a worst-case scenario. Maximum water-level declines for each aquifer zone in simulation B and simulations C1 through C5 were added. The following maximum water-level declines were computed for each aquifer zone: surficial, $29.8 \mathrm{ft}$; zone A, $22.2 \mathrm{ft}$; zone B, $19.4 \mathrm{ft}$; zone C, $19.4 \mathrm{ft}$; zone D, 18.7. $\mathrm{ft}$; zone $\mathrm{E}, 16.4 \mathrm{ft}$; and zone $\mathrm{F}, 27.6 \mathrm{ft}$. 


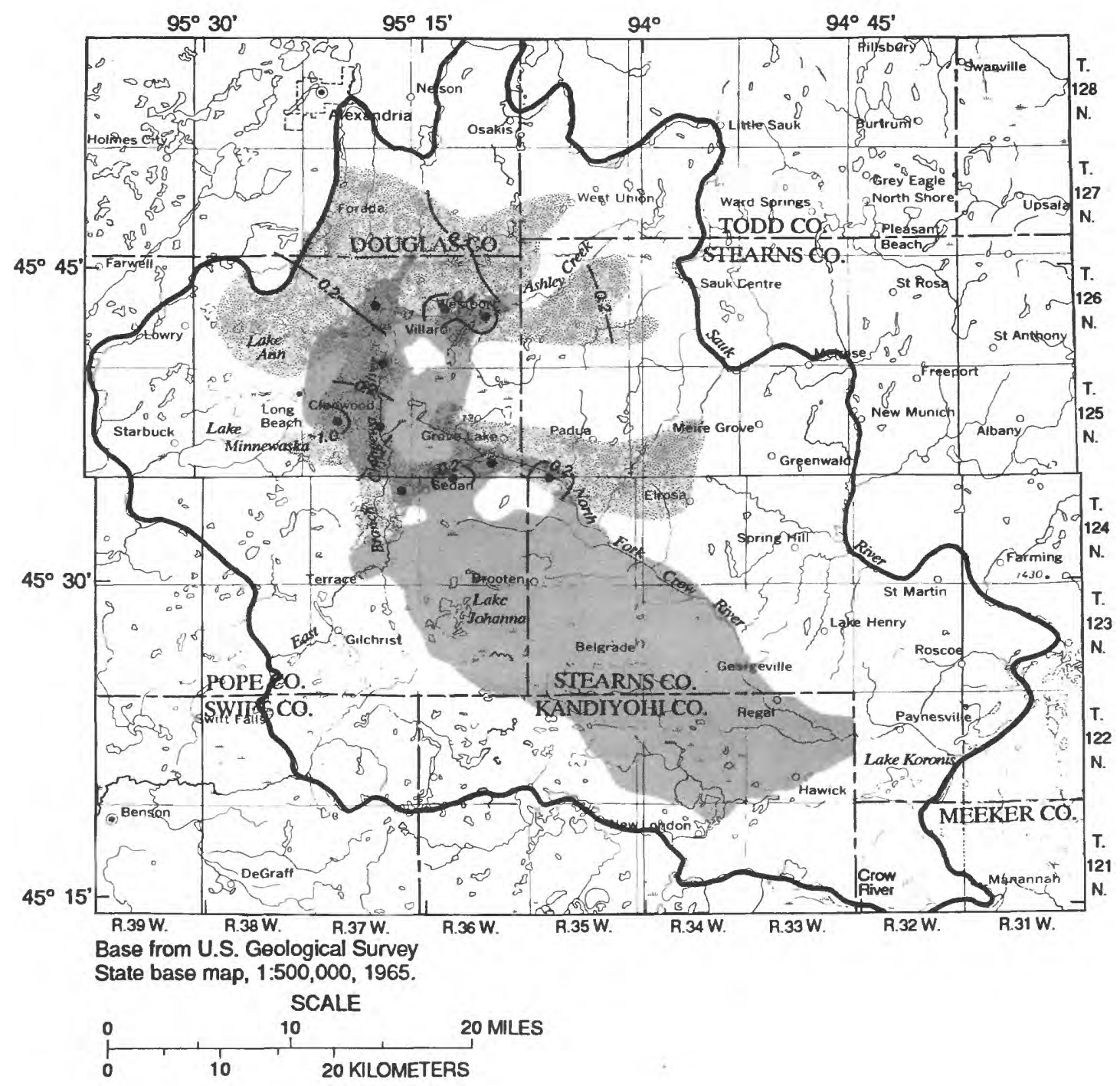

\section{EXPLANATION}

Area in which ground-water flow was simulated (aquifer)

Study area

Hydrological boundary

- 0.2- Water-level-decline contour. Shows modelcomputed water-level declines. Interval variable.

- Hypothetical pumped well

Figure 32.--Model computed water-level declines in zone A (layer 2) following increased development (simulation C1) 


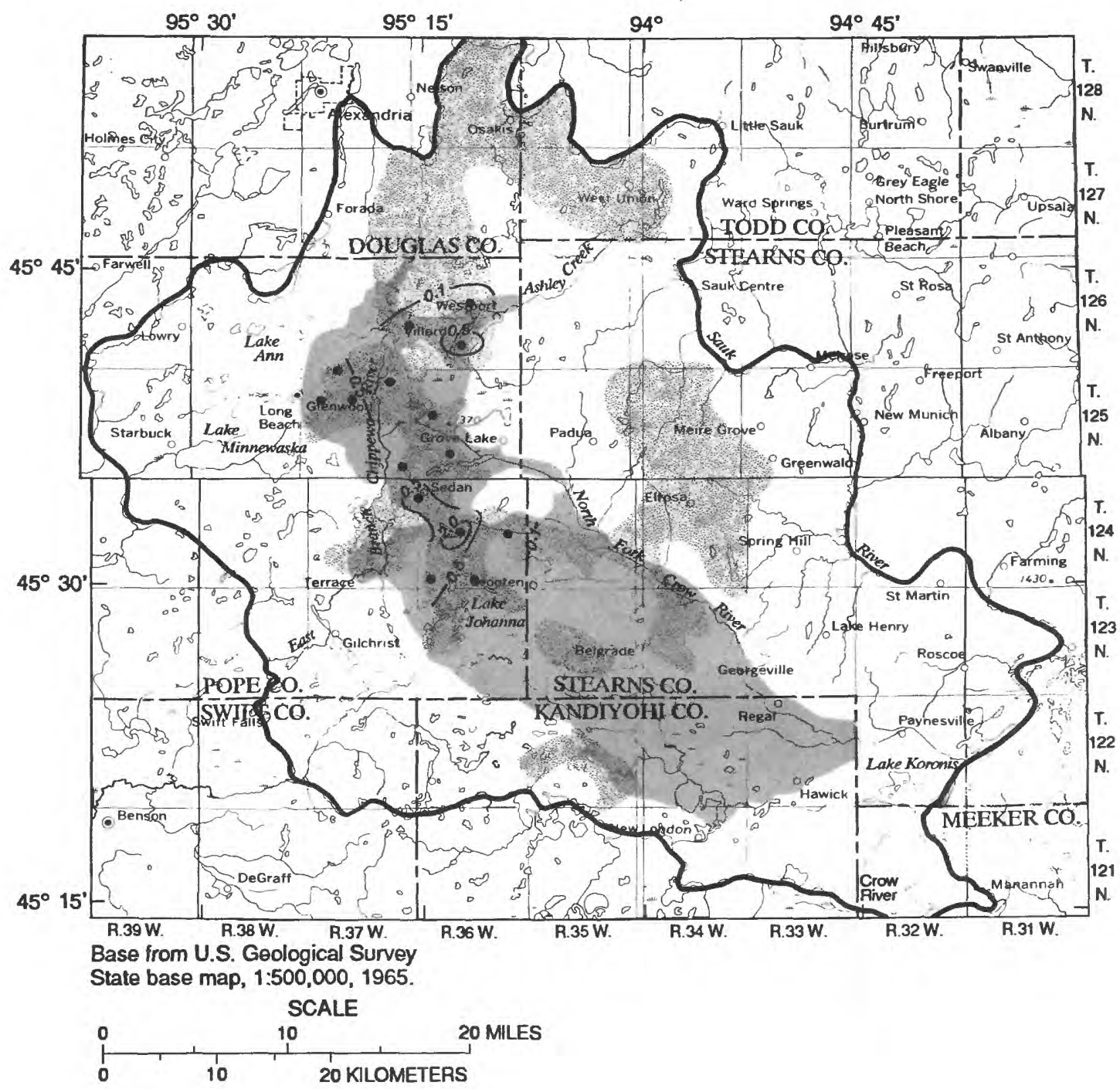

\section{EXPLANATION}

Area in which ground-water flow was simulated (aquifer)

Study area

Hydrological boundary

- 0.5 - Water-level-decline contour. Shows modelcomputed water-level declines. Interval variable.

- Hypothetical pumped well

Figure 33.--Model computed water-level declines in zone B (layer 3 ) following increased development (simulation C2) 


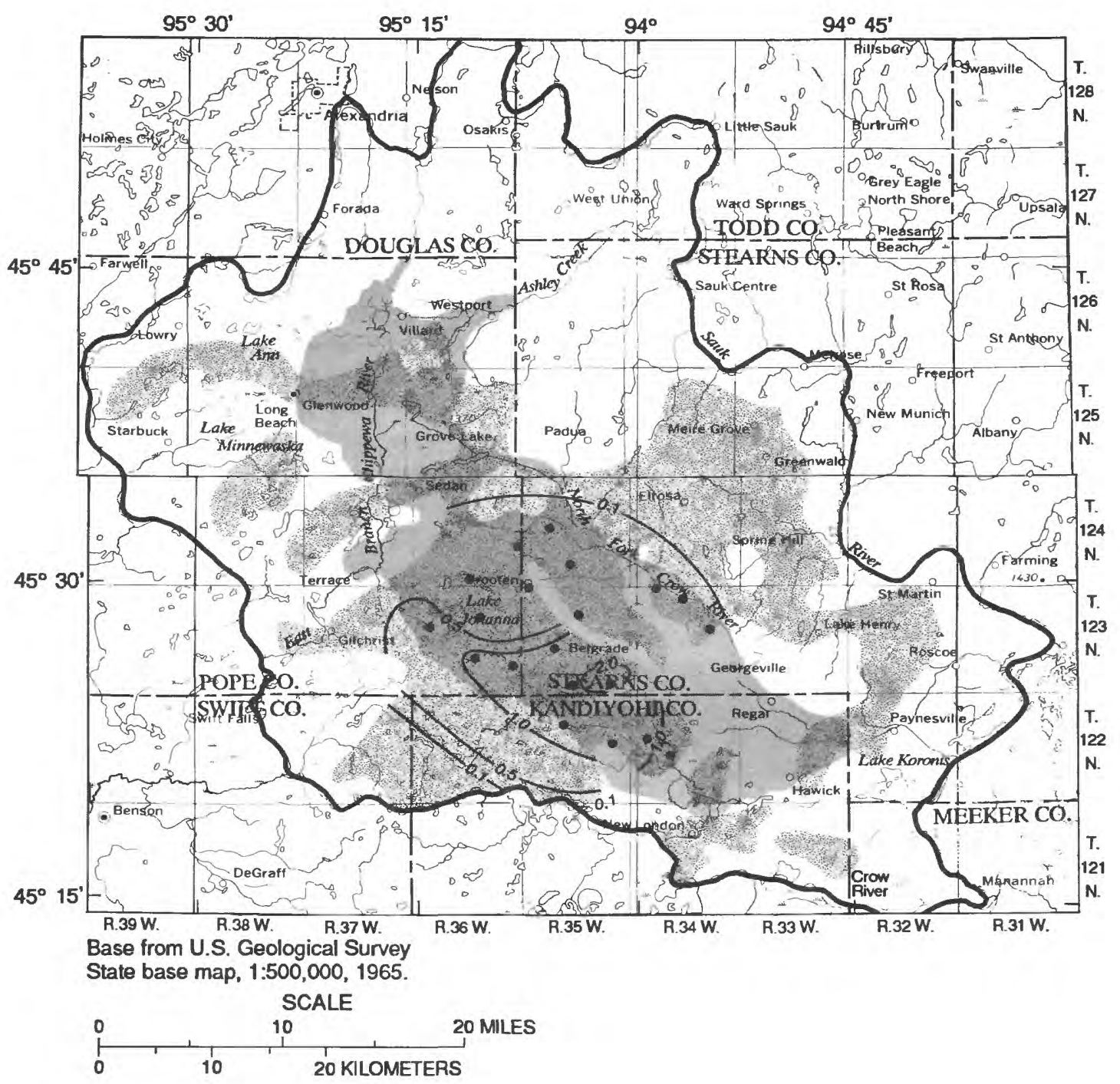

\section{EXPLANATION}

Area in which ground-water flow was simula
(aquifer)
Study area
Hydrological boundary
$-0.5-\quad \begin{aligned} & \text { Water-level-decline contour. Shows model- } \\ & \text { computed water-level declines. Interval } \\ & \text { variable. }\end{aligned}$

- Hypothetical pumped well

Figure 34.--Model-computed water-level declines in zone $\mathrm{C}$ (layer 4 ) following increased development (simulation C3) 


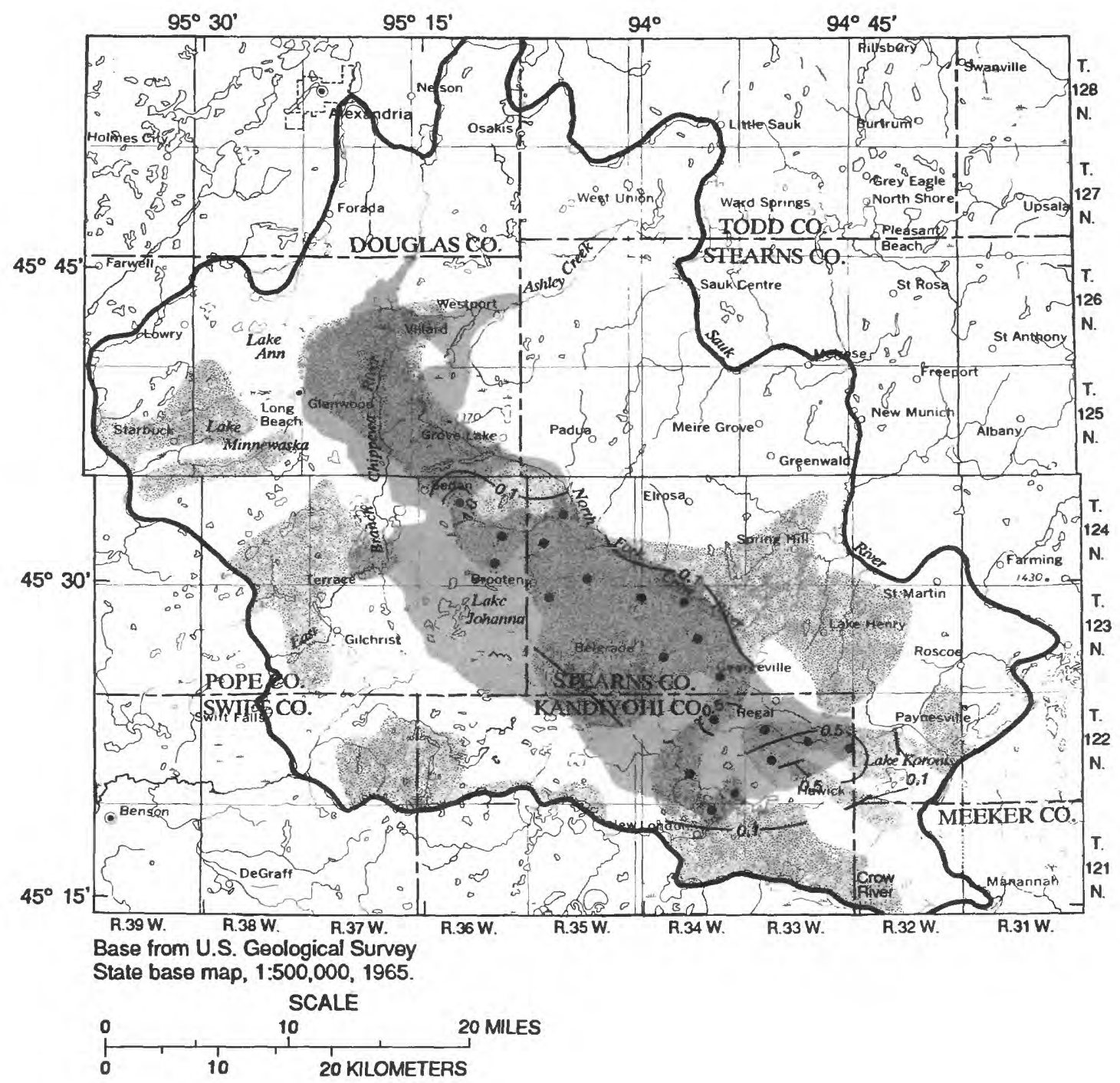

\section{EXPLANATION}

Area in which ground-water flow was simulated (aquifer)

Study area

Hydrological boundary

-0.5- Water-level-decline contour. Shows modelcomputed water-level declines. Interval variable.

- Hypothetical pumped well

Figure 35.--Model-computed water-level declines in zone D (layer 5) following increased development (simulation C4) 


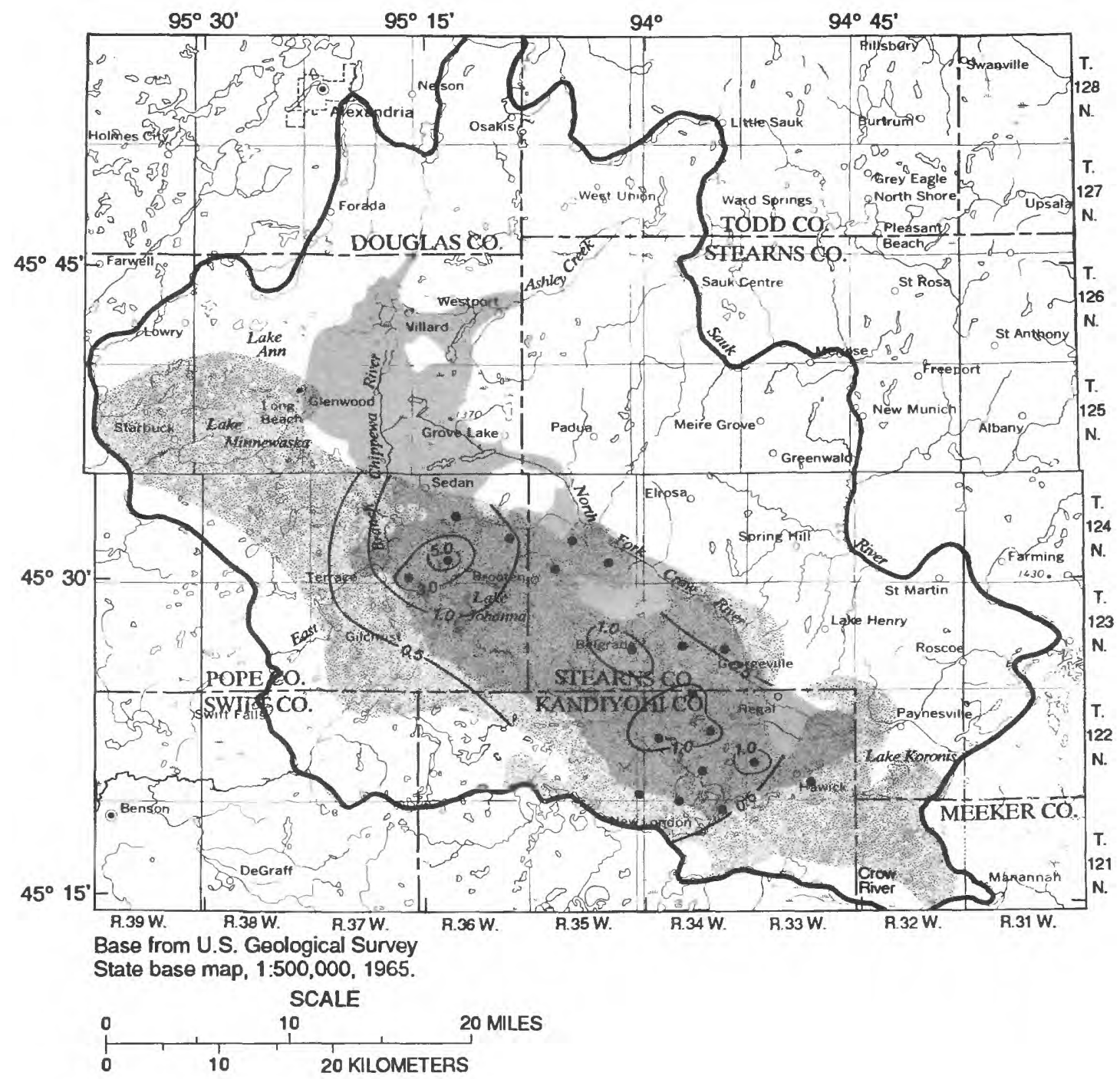

\section{EXPLANATION}

Area in which ground-water flow was simulated (aquifer)

Study area

Hydrological boundary

- 0.5 - Water-level-decline contour. Shows modelcomputed water-level declines. Interval variable.

- Hypothetical pumped well

Figure 36.--Model-computed water-level declines in zone $\mathrm{E}$ (layer 6) following increased development (simulation C5) 


\section{Mode1 Limitations}

The ground-water-flow model is a practical tool for simulating response of the ground-water system to projected climatic conditions and proposed development schemes. However, the model necessarily is a simplification of a complex flow system. As a result of the complex lithology of the drift, multiple confined aquifers were necessarily simulated in each model layer. Although beyond the scope of this study, a more accurate simulation of flow in the area would require dividing the drift system into many more layers and the dividing area into smaller cell blocks. The scale of the model precludes its use for ground-water analyses in local areas. More detailed models of local areas are needed for site-specific analyses.

The accuracy of model results is limited by the accuracy of the data that describe aquifer and confining-bed properties, areal-recharge rates, evapotranspiration rates, and boundary conditions. In addition, a different combination of input data could produce the same results. Quantitative field data for areal recharge, river-bed-leakage coefficient, amount of irrigation water returned to the ground-water system, ground-water loss to evapotranspiration, and additional geologic data would allow for a more accurate calibration of the model. Improvements in the accuracy of estimates of areal recharge and evapotranspiration rates would greatly enhance model accuracy and, therefore, the simulated response to drought and increased pumpage. Without these data, model results are subject to large errors. As additional data become available, the model could be modified and recalibrated to transient conditions to improve its accuracy. Because of the complexity of ground-water flow in a drift system such as the one in the Brooten-Belgrade area, it is recommended that future model simulations include horizontal and vertical flow through till confining units.

Caution should be used in making ground-water management decisions based on the steady-state model simulations described in this report. Declines in potentiometric surface computed for hypothetical simulations A through C5 represent average declines over grid blocks covering $1 \mathrm{mi}^{2}$. Actual water-level declines in wells will differ from computed values, and declines in or near individual high-capacity pumping wells generally will be greater. Because simulations A through C5 are steady-state simulations, results do not reflect the seasonal effects of climatic and pumping stresses. Rather, the results represent the long-term effects of the stresses applied. Steady-state simulations do not consider water from storage, which may appreciably affect shortterm changes in water leve1. Pumping from wells in a confined aquifer results in a reduced confining-bed porosity and a corresponding reduction in drainage of water from the confining beds. Consequently, less water is available for withdrawal and water-level declines increase after an aquifer has been stressed for an extended period of time. A transient-state ground-water-flow model would need to be constructed to simulate seasonal fluctuations in pumping and climatic stress. Long-term monitoring of water levels in the confined and surficial aquifers is necessary to construct a transient model. 


\section{SUMMARY AND CONCLUSIONS}

Ground-water withdrawals from drift aquifers have increased dramatically during the 1970's and $1980^{\prime}$ s in western Minnesota. The increase resulted primarily from an increase in ground water used for irrigation following the 197677 drought. In the Brooten-Belgrade area, west-central Minnesota, an increasing percentage of the total irrigation pumpage is from confined-drift aquifers. Management of this ground-water resource requires an understanding of the behavior of this complex aquifer system. Consequently, a ground-water-flow model was constructed to provide information on the regional behavior of the system.

The drift-aquifer system consists of a surficial aquifer and a series of confined aquifers that can be grouped in six zones. These aquifer zones are separated by confining layers consisting of lower-permeability till ranging in thickness from about $5 \mathrm{ft}$ to about $220 \mathrm{ft}$. The head in each of the aquifers generally decreases with depth, indicating downward flow, except near major streams, lakes, and wetlands where head increases with depth and flow is upward.

Steady-state calibration of the model resulted in acceptable agreement between simulated potentiometric surfaces and measured values of head. The absolute value of the mean difference between model-computed and measured potentiometric surfaces for the seven model layers ranged from 0.6 to $8.9 \mathrm{ft}$. Model-computed steady-state ground-water discharge to the East Branch Chippewa and North Fork Crow Rivers generally is within the range of measured discharge rates. The model results indicate that about 96 percent of the inflow to the model area is recharge from precipitation. Of the total ground-water outflow, about 63 percent is seepage to the East Branch Chippewa and North Fork Crow Rivers, and 34 percent is pumpage.

The model indicates that ground-water flow between the various drift aquifers is considerable. For example, the model computed steady-state ground-water flow of approximately 2,800 $\mathrm{Mgal} / \mathrm{yr}$ from overlying deposits to aquifers in zone C. Conversely, leakage to the most deeply buried aquifers in zone $F$ was estimated by the model to be approximately $40 \mathrm{Mgal} / \mathrm{yr}$.

Model results indicate that the effects of historical and 1984 pumping has lowered water levels from 5 to $10 \mathrm{ft}$ regionally in all confined and unconfined aquifers, and as much as $15 \mathrm{ft}$ locally near Belgrade in the surficial aquifer and in zone $C$ aquifers. Decreased recharge and increased pumping during a 3year hypothetical drought may lower water levels an additional 2 to $10 \mathrm{ft}$ regionally in each aquifer zone, compared to 1984 water levels. Water-level declines of as much as $20 \mathrm{ft}$ may occur locally in the surficial aquifer following a drought similar to a hypothetical 3-year drought simulated in the model analysis. Ground-water discharge to the East Branch Chippewa and North Fork Crow Rivers in the modeled area during the simulated drought was reduced by 38 percent from 1984 conditions.

Model simulations of hypothetical ground-water development indicate that the confined aquifers in the Brooten-Belgrade area are capable of supporting additional pumping. Model results indicate that the addition of 10 hypotheti- 
cal high-capacity wells in zone $\mathrm{A}$, pumping a total of $123 \mathrm{Mgal} / \mathrm{yr}$, would lower water levels about 0.2 to $0.4 \mathrm{ft}$ regionally. The addition of 15 hypothetical high-capacity wells in zone B, pumping a total of $184.5 \mathrm{Mgal} / \mathrm{yr}$, would lower water levels about 0.1 to $0.5 \mathrm{ft}$ regionally. The addition of 20 hypothetical high-capacity wells in zone $\mathrm{C}$, pumping a total of $246 \mathrm{Mgal} / \mathrm{yr}$, would lower water levels about 0.1 to $1 \mathrm{ft}$ regionally. The addition of 20 hypothetical high-capacity wells in zone D, pumping a total of $246 \mathrm{Mgal} / \mathrm{yr}$, would lower water levels about 0.1 to $0.5 \mathrm{ft}$ regionally. The addition of 20 hypothetical high-capacity wells in zone $\mathrm{E}$, pumping a total of $246 \mathrm{Mgal} / \mathrm{yr}$, would lower water levels about 0.5 to $1 \mathrm{ft}$ regionally.

The ground-water-flow model is a practical tool for understanding operation of the ground-water system. However, the accuracy of model results is limited by the accuracy of the data that describe aquifer and confining-bed properties, recharge rates, evapotranspiration rates, and boundary conditions. Caution should be used in making ground-water management decisions based on the steady-state simulations. Actual water-level declines in wells may differ from model-computed values, and declines in or near individual high-capacity pumping wells generally will be greater. As additional data become available, the model could be modified and recalibrated to improve its accuracy. Long-term water-level data would be necessary to calibrate a transient-state groundwater-flow model. A transient model could be used to investigate seasonal fluctuations in pumping and in climatic stress. The scale of the model precludes its use for ground-water analyses in local areas. More detailed models of local areas are needed for site-specific analyses. 


\section{REFERENCES CITED}

Allison, I. S., 1932, The geology and water resources of northwestern Minnesota: University of Minnesota, Minnesota Geological Survey Bulletin 31, $506 \mathrm{p}$.

Baker, D. G., and Kuehnast, E. A., 1978, Climate of Minnesota Part X, Precipitation normals for 1941-1970: Minnesota Agricultural Experiment Station Technical Bulletin 314, 15 p.

Baker, D. G., Nelson, W. W., and Kuehnast, E. A., 1979, Climate of Minnesota Part XII, The hydrologic cycle and soil and water: Minnesota Agricultural Experiment Station Technical Bulletin 322, 23 p.

Baker, D. G., and Strub Jr., J. H., 1965, Climate of Minnesota Part III, Temperature and its application: Minnesota Agricultural Experiment Station Technical Bulletin 248, 62 p.

Cotter, R. D., Bidwell, L. E., Van Voast, W. A., and Novitski, R. P., 1968, Water resources of the Chippewa River watershed, west-central Minnesota: U. S. Geological Survey Hydrologic Investigations Atlas HA-286, 4 sheets, scale $1: 250,000$.

Delin, G. N., 1986a, Hydrogeology of confined-drift aquifers near the Pomme de Terre and Chippewa Rivers, western Minnesota: U. S. Geological Survey WaterResources Investigations Report 86-4098, 90 p.

$1986 \mathrm{~b}$, Evaluation of avallability of water from drift aquifers near the Pomme de Terre and Chippewa Rivers, western Minnesota: U. S. Geological Survey Water-Resources Investigations Report 86-4321, 62 p.

1988, Hydrogeology of confined-drift aquifers in the Brooten-Belgrade area, east-central Minnesota: U. S. Geological Survey Water-Resources Investigations Report 88-4124, $162 \mathrm{p}$.

Franke, O. L., Reilly, T. E., and Bennett, G. D., 1984, Definition of boundary and initial conditions in the analysis of saturated ground-water flow systems - an introduction: U. S. Geological Survey Open-File Report 84-458, $26 \mathrm{p}$.

Hal1, C. W., Meinzer, O. E., and Fuller, M. L., 1911, Geology and underground waters of southern Minnesota: U. S. Geological Survey Water-Supply Paper 256, 406 p.

Helgesen, J. O., Ericson, D. W., and Lindholm, G. F., 1975, Water resources of the Mississippi and Sauk Rivers watershed, central Minnesota: U. S. Geological Survey Hydrologic Investigations Atlas HA-534, 3 sheets, scale $1: 250,000$.

Horn, M. A., 1984, Development of a water-use data system in Minnesota: U. S. Geological Survey Water-Resources Investigations Report 84-4306, 59 p.

Larson, S. P., 1976, An appraisal of ground-water for irrigation in the Appleton area, west-central Minnesota: U. S. Geological Survey Water-Supply Paper 2039-B, 34 p.

Leverett, Frank, 1932, Quaternary geology of Minnesota and parts of adjacent states: U. S. Geological Survey Professional

Paper 161, 149 p.

Lindholm, G. F., 1980, Ground-water appraisal of sand plains in Benton, Sherburne, Stearns, and Wright Counties, central Minnesota: U. S. Geological Survey Water-Resources Investigations Open-File Report 80-1285, 103 p.

Lindholm, G. F., Farre11, D. F., and Helgesen, J. 0., 1974, Water resources of the Crow River watershed, south-central Minnesota: U. S. Geological Survey Hydrologic Investigations Atlas Ha-528 
Lindholm, G. F., and Norvitch, R. F., 1976, Ground water in Minnesota: U. S. Geological Survey Open-File Report 76-354, 100 p.

McDonald, G. M., and Harbaugh, A. W., 1984, A modular three-dimensional finitedifference ground-water flow mode1: U. S. Geological Survey Open-File Report $83-875,528 \mathrm{p}$.

Rasmussen, W. C., and Andreason, G. E., 1959, Hydrologic budget of the Beaverdam Creek Basin, Maryland: U. S. Geological Survey Water-Supply Paper $1472,106 \mathrm{p}$.

Reilly, T. E., Franke, O. L, and Bennett, G. D., 1984, The principle of superposition and its application in ground-water hydraulics: U. S. Geological Survey Open-File Report 84-459, 36 p.

Ross, L. M., 1971, An evaluation of irrigation potential in the bonanza valley: Agricultural Experiment Station and Agricultural Extension Service Bulletin, $19 \mathrm{p}$.

Soukup, W. G., Gillies, D. C., and Myette, C. F., 1984, Appraisal of the surficial aquifers in the Pomme de Terre and Chippewa River valleys, western Minnesota: U. S. Geological Survey Water-Resources Investigations Report 844086, $63 \mathrm{p}$.

Stoner, J. D., and Streitz, A. R., 1987, Locating confined aquifers in glacial drift with seismic reflection methods, western Minnesota: Geological Society of America North-Centra1 Section - Abstracts with programs 1987, 248 p.

Thei1, G. A., 1944, Geology and underground waters of southern Minnesota: University of Minnesota: Minnesota Geological Survey Bulletin 31, 506 p.

Thornthwaite, C. W., and Mather, J. R., 1957, Instructions and tables for computing potential evapotranspiration and water balance: Drexel Institute of Technology, Publications in Climatology, v. 10, no. 3, 311 p.

Van Voast, W. A., 1971, Ground-water for irrigation near Lake Emily, Pope County, west-centra1 Minnesota: U. S. Geologica1 Survey Water-Supply Paper $1899-\mathrm{J}, 28$ p.

Winche11, N. H., and Upham, Warren, 1888, The geology of Minnesota: Minnesota Geological and Natural History Survey Final Report, v. 2, 695 p.

Wolf, R. J., 1976, Buried aquifers in the Brooten-Belgrade and Lake Emily areas, west-central Minnesota -- factors related to developing water for irrigation: U. S. Geological Survey Water-Resources Investigations Report $76-100,72 \mathrm{p}$.

Wright, H. E., Jr., 1972a, Quaternary history of Minnesota, in Sims, P. K., and Morey, G. B., eds., Geology of Minnesota: A centennial volume: Minnesota Geological Survey, p. 515-546

1972b, Physiography of Minnesota, in Sims, P.K., and Morey, G. B., eds., Geology of Minnesota: A centennial volume: Minnesota Geological Survey, p. $561-578$.

Wright, H. E., Jr., and Ruhe, R. V., 1965, Glaciation of Minnesota and Iowa, in Wright, H. E., Jr., and Frey, D. G., eds., The Quaternary of the United States: p. 29-41. 